\title{
Commercial Building End-Use Energy Metering Inventory
}

\author{
J.A. Heidell \\ R.P. Mazzucchi \\ R.W. Reilly
}

March 1985

Prepared for the U.S. Department of Energy under Contract DE-AC06-76RLO 1830

Pacific Northwest Laboratory Operated for the U.S. Department of Energy by Battelle Memorial Institute 


\title{
DISCLAIMER
}

This report was prepared as an account of work sponsored by an agency of the United States Government. Neither the United States Government nor any agency thereof, nor any of their employees, makes any warranty, express or implied, or assumes any legal liability or responsibility for the accuracy, completeness, or usefulness of any information, apparatus, product, or process disclosed, or represents that its use would not infringe privately owned rights. Reference herein to any specific commercial product, process, or service by trade name, trademark, manufacturer, or otherwise, does not necessarily constitute or imply its endorsement, recommendation, or favoring by the United States Government or any agency thereof. The views and opinions of authors expressed herein do not necessarily state or reflect those of the United States Government or any agency thereof.

\author{
PACIFIC NORTHWEST LABORATORY \\ operated by \\ BATTELLE \\ for the \\ UNITED STATES DEPARTMENT OF ENERGY \\ under Contract DE-AC06-76RLO 1830
}

Printed in the United States of America
Available from
National Technical Information Service
United States Department of Commerce
5285 Port Royal Road
Springfield, Virginia 22161
NTIS Price Codes
Microfiche A01
Printed Copy
Pages
$001-025$
$026-050$
$051-075$
$076-100$


PNL -5027

UC-95d

COMMERCIAL BUILDING END-USE ENERGY

METER ING INVENTORY

J. A. Heidell
R. P. Mazzucchi
R. W. Reilly

March 1985

Prepared for the

Architectural and Engineering Systems Branch

Building Systems Division

U.S. Department of Energy

under Contract DE-AC06-76RLO 1830

Pacific Northwest Laboratory

Richland, Washington 99352 


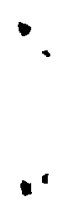

- 


\section{ACKNOWLEDGMENT}

The authors thank all the individuals who provided their time and assistance in identifying and describing building metering projects. We apologize for any inaccuracies and would appreciate being notified about them. The authors also thank the individuals who assisted with identifying data needs during the Technical Advisory Committee meeting in Washington, D.C. during June, 1983, and Donald Fry and Michael Holtz of Architectural Energy Corporation for their assistance with this study. 
1

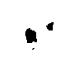

$\therefore$

- 


\section{SUMMARY}

Pacific Northwest Laboratory (PNL) has completed a comprehensive inventory of existing sources of measured end-use energy consumption data for commercial buildings that typify common design practices. The study comprises one task within the Commercial Buildings Metering Project, which is one element of the Commercial Buildings Energy Use and Design Program managed by PNL for the U.S. Department of Energy. The goal of the project is to provide an empirical, well documented, end-use energy consumption data base for researchers in the fields of building design, equipment manufacturing, public policy, energy-use simulation models, building control, and utility load forecasting. Although data requirements for these purposes have traditionally been.served by end-use computer simulations, empirical data are desirable to evaluate the suitability of reliance upon simulations, and also to provide an alternative when simulation techniques do not provide the required level of detail, time resolution, or accuracy.

The inventory included contacts with over 250 individuals and organizations likely to have metered data. The organizations contacted included utilities, federally-sponsored national laboratories, state energy offices, federal agencies, architectural and engineering firms, universities, trade and professional organizations, and building equipment manufacturers. Contacts were made directly through mailed questionnaires and phone interviews, and indirectly through advertisements in trade and professional magazines. In addition, a literature search was conducted and previous inventories were reviewed.

Two major findings resulted from the inventory. The first is that there are few well-documented sources of metered end-use data in the public domain. The second is that a well-documented and widely-available data base of metered end-use data is of value to the building research community.

The study identified 37 data sets in which most end-uses in "typical" commercial buildings are individually metered: 8 large office buildings, 1 small office building, 11 restaurants, 8 hotels and motels, 4 large grocery stores, 3 multifamily dwellings, and 2 retail stores. Few of the 37 data sets contain both complete records of energy consumption and sufficient documentation to 
serve the research needs defined in this report. Further review of the data is necessary to determine whether they are usable for specific purposes. A preliminary assessment of the data indicates that there are a sufficient quality and quantity of data on restaurants, hotels, and large office buildings to serve many research needs that require a small sample of buildings. A more definitive assessment must wait until ongoing metering efforts are completed, and a detailed analysis of the completed projects can be made. 


\section{CONTENTS}

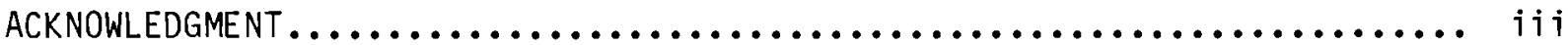

SUMMARY........................................... v

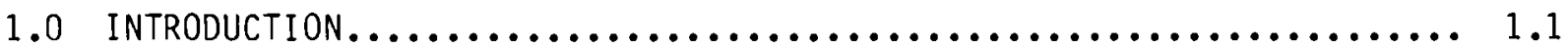

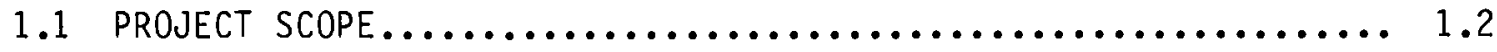

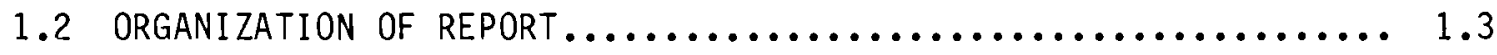

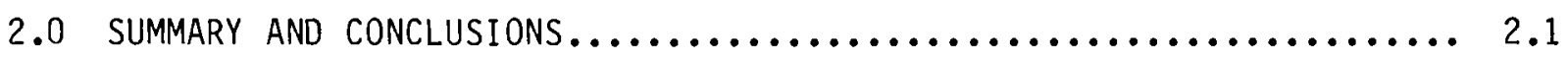

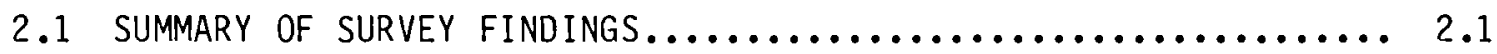

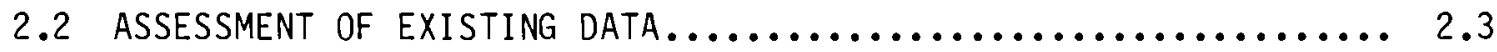

2.2.1 Assessment of Statistically-Based Research Data....... 2.4

2.2.2 Assessment of Operations Research Based Data......... 2.4

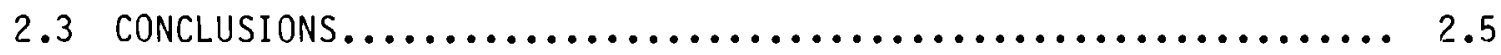

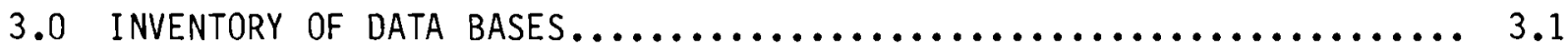

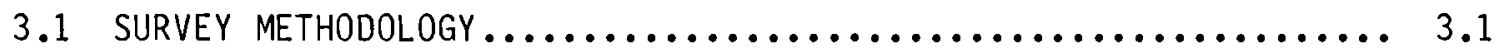

3.2 SUMMARY DESCRIPTION OF EXISTING DATA SETS $\ldots \ldots \ldots \ldots \ldots \ldots \ldots \ldots . . \ldots$

3.2 .1 Existing Surveys......................... 3.2

3.2 .2 New Surveys.............................. 3.4

3.2.3 Literature Survey........................ 3.7

3.2 .4 Journal Notices......................... 3.8

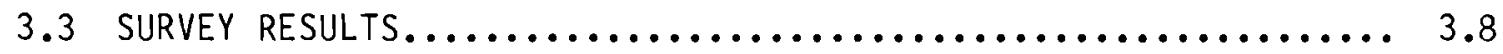

3.3.1 Multiple Building Projects................... 3.13

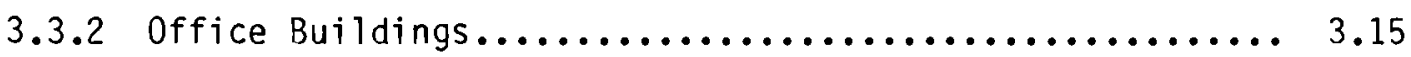

3.3 .3 Restaurants.............................. 3.20

3.3 .4 Hotels and Motels.......................... 3.22

3.3.5 Miscellaneous Projects...................... 3.22 
4.0 DATA REQUIRED FOR RESEARCH OBJECTIVES $\ldots \ldots \ldots \ldots \ldots \ldots \ldots \ldots \ldots \ldots \ldots \ldots$

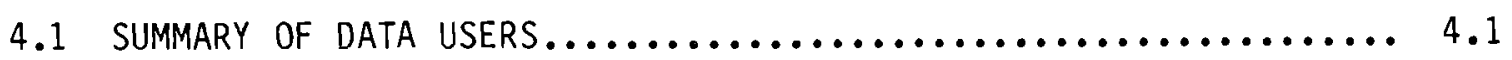

4.1 .1 Operations-Research-Based Data................ 4.2

4.1 .2 Statistical-Based Data....................... 4.5

4.2 DATA REQUIRED TO AdDRESS RESEARCH NEEDS................ 4.7

4.7

4.3 PERFORMANCE FACTORS ........................... 4.11

4.3.1 Energy Consumption and Peak Demand............... 4.12

4.3.2 Energy Performance Ratios..................... 4.12

4.3.3 Equipment and Component Efficiencies.............. 4.13

4.3.4 Building Shell Parameters.................... 4.14

4.3.5 Indoor Thermal Comfort Measures................. 4.14

4.3.6 Summary of Performance Factors................. 4.15

5.0 DOCUMENTATION OF METERED DATA INVENTORY $\ldots \ldots \ldots \ldots \ldots \ldots \ldots \ldots \ldots \ldots \ldots$

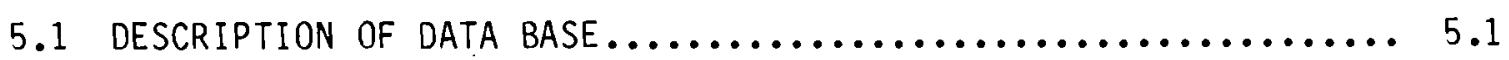

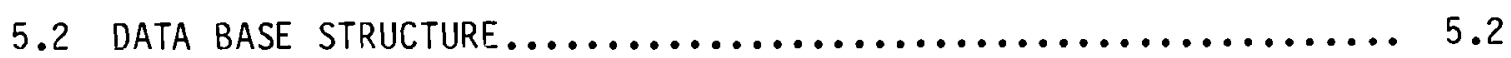

6.0 SUMMARY OF END-USE METERING PROJECTS MEETING PROGRAM CRITERIA...... 6.1

6.1 PROJECT ON RESTAURANT ENERGY PERFORMANCE................ 6.1

6.1 .1 Fast Food............................... 6.2

6.1 .2 Full Service Restaurant....................... 6.2

6.1 .3 Coffee Shop............................. 6.4

6.1 .4 Cafeteria............................. 6.4

6.1 .5 Pizza House............................ 6.7

6.1 .6 Fast Food Extended Menu..................... 6.7

6.1 .7 Ful1 Service Limited Menu..................... 6.10 


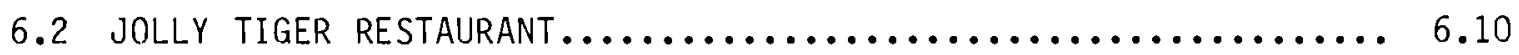

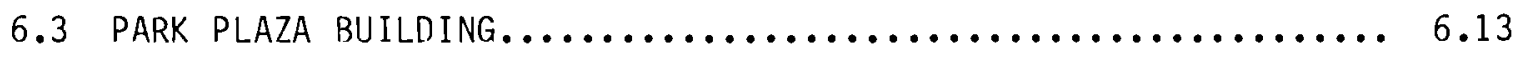

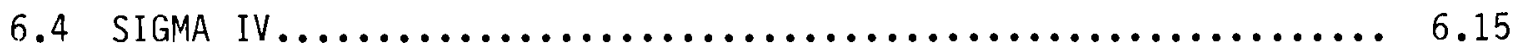

6.5 HOTELS AND MOTELS $\ldots \ldots \ldots \ldots \ldots \ldots \ldots \ldots \ldots \ldots \ldots \ldots \ldots \ldots \ldots \ldots \ldots \ldots \ldots$

6.5 .1 Description of Facilities................... 6.17

6.5.2 Energy Consumption Profiles.................... 6.20

6.6 SEATTLE CITY LIGHT............................ 6.23

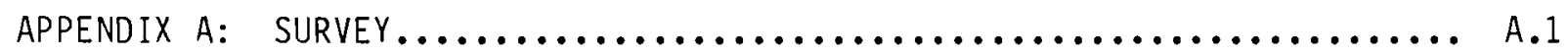

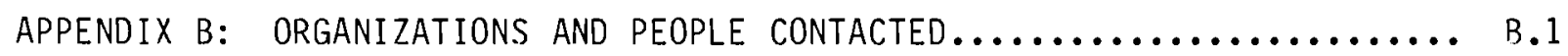

APPENDIX $\mathrm{c}:$ ANNOUNCEMENTS AND ADVERTISEMENTS $\ldots \ldots \ldots \ldots \ldots \ldots \ldots \ldots \ldots \ldots . .$.

APPENDIX D: THE BONNEVILLE POWER ADMINISTRATION END-USE

LOAD AND CONSERVATION ASSESSMENT PROGRAM.............. D.1

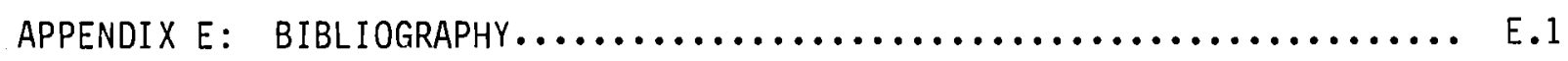




\section{$\underline{\text { TABLES }}$}

2.1 Metered Data Projects Meeting Project Criteria................ 2.3

3.1 Breakdown of Metering Sites for Sierra Pacific Study............ 3.7

3.2 Description of Metering Projects ............................. $3 . \ldots$

3.3 List of End-Use Metering Projects.............................

3.4 Total Energy Use Metered Data......................... 3.12

4.1 Uses of Detailed Data............................. 4.2

4.2 Uses of Statistical Data Collection Efforts................... 4.5

4.3 Ranking of Research Areas.............................. 4.8

4.4 Guide to the Commercial Building Metering Program.............. 4.9

4.5 Energy Consumption and Peak Demand Performance Factors.......... 4.13

4.6 Energy Ratio Performance Factors.......................... 4..14

4.7 Equipment and Component Performance Factors.................. 4.15

4.8 Building Shell Performance Factors....................... 4.15

4.9 Indoor Comfort Performance Factors..................... 4.15

5.1 Data Base Variables................................ 5.3

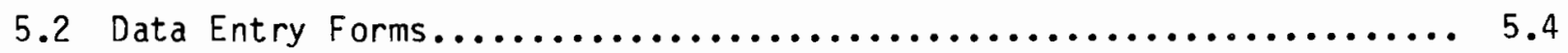

5.3 Survey Data Entry Form............................. 5.5

5.4 Meter Data Entry Form.............................. 5.5

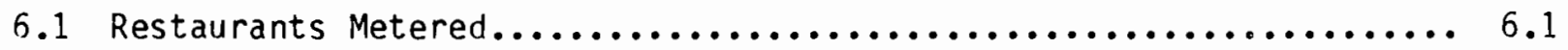

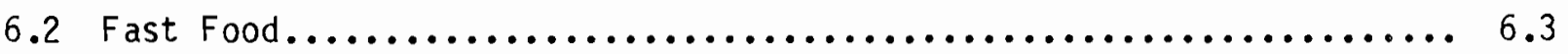

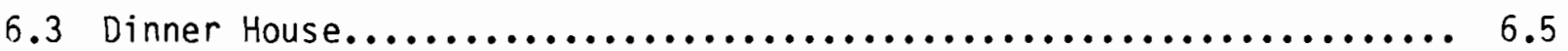

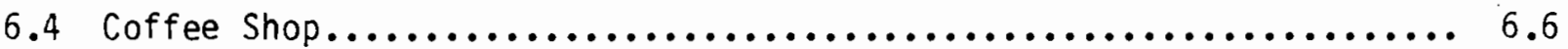

6.5 Cafeteria....................................... 6.8

6.6 Pizza House..................................... 6.9 


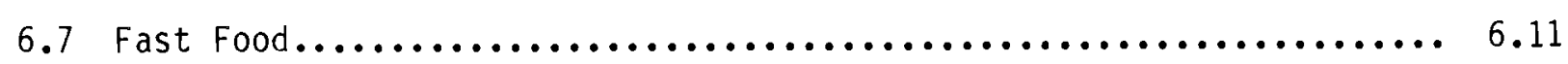

6.8 Dinner House........................................ 6.12

6.9 Jolly Tiger Restaurant Annual End-Use Energy Consumption......... 6.14

6.10 Heat Recovery for the Jolly Tiger Restaurant................. 6.15

6.11 Park Plaza Research Building - in MBtu..................... 6.16

6.12 Reclaimed Energy from Park Plaza Building.................. 6.17

6.13 Sigma IV End-Use Energy Consumption in kWh.................. 6.18

6.14 Average Energy Consumption Per Available Room/Per Day............ 6.21

6.15 Kitchen Average Energy Use Per Meal...................... 6.22

6.16 Laundry Energy use in Btu Per Available Room/Per Day............ 6.23

6.17 Total Energy Consumption in KBtu........................ 6.24

6.18 Seattle City Light Metered Facilities...................... 6.25 
-

$\checkmark$

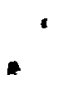




\subsection{INTRODUCTION}

Pacific Northwest Laboratory (PNL), managed for the U.S. Department of Energy by Battelle Memorial Institute, is conducting a long-term research program focused on understanding energy use in commercial buildings for DOE's Office of Building Energy Research and Development (BERD). One element of this program, the Commercial Buildings Energy Use and Design Program, involves the collection of empirical end-use metered data for typical commercial buildings. Architects and engineers rely predominantly upon computer models and rules of thumb to provide detailed information on energy use. This research effort is focused upon developing an understanding of how energy is used in actual buildings in order to assist architects, engineers, and related professionals in understanding how energy can be saved. Empirical end-use data is important for corroborating estimates and simulations of energy use in buildings and for supporting related research on computer simulation codes, design of energyefficient buildings, identification of conservation strategies, and policymaking.

This report documents the status of end-use data collection efforts for commercial buildings and reviews the characteristics of this data and its suitability for meeting research requirements. The identification of metered enduse data is an ongoing process and this report may be updated periodically to include additional data descriptions. Further investigation of selected metered end-use data sets is planned and additional reports analyzing the data will be prepared as part of the metering project.

An inventory of end-use metering activities was conducted through mail and telephone survey to establish whether suitable metered data exist to support program objectives, thereby determining the necessity for federally-supported metering of commercial buildings. Although a number of surveys have been conducted related to sources of metered and related data on commercial building energy consumption, none have been focused upon identifying and documenting sources of end-use metered data for typical commercial buildings. 


\subsection{PROJECT SCOPE}

The principal goal of the Commercial Building Metering and Data Base Development Project is to:

Establish an end-use empirical data base for commercial buildings that can support advanced research on the physics of building energy use and energy conservation techniques.

The target data base contains end-use energy consumption data, supplemented with information pertaining to the characteristics of the buildings from which each data set is collected. These characteristics include: construction features, occupancy and operation schedules, equipment efficiency, and weather data. Given the broad categories and construction practices related to commercial buildings, a subset of these buildings has been identified within the domain of this research project. This subset contains commercial buildings that generally represent "typical" design and construction practices of the post-1973 0il Embargo era. Buildings designed to demonstrate exotic or innovative design techniques, or to incorporate active and passive solar design techniques, are specifically excluded from this study. The purpose of this effort is to provide information on typical "base-case" buildings that can be contrasted with information on these more advanced buildings. The more advanced buildings are generally the subjects of other government-sponsored research projects, such as the DOE Passive Solar Commercial Buildings Program managed by Ron Lutha in DOE's Chicago Operations Office. Special case studies for energyefficient buildings are also currently being studied as part of the Building Energy Compilation \& Analysis (BECA) program at the Lawrence Berkeley Laboratory.

End-use data is defined as energy use data collected separately for a minimum of lighting, heating ventilation, and air conditioning (HVAC), water heating, and other processes. Lighting energy includes the primary space lighting fixtures. Exterior lighting should be metered separately. HVAC energy should be separated into heating, cooling, and ventilation energy use categories. Water heating energy use refers to domestic and process water heating. Process energy is site-specific. 
During the course of the inventory a number of metering efforts were identified in which: 1) the buildings were specially constructed to incorporate passive and active solar design features, 2) the total (only) energy use was metered on an hourly or sub-hourly basis, and 3) selected end uses in buildings were metered. These cases do not meet this particular program's requirements, but are referenced in the data base. Buildings that are characterized as having been specially constructed to demonstrate active or passive solar design features are not considered in the project objectives since they are atypical of existing building stock and are studied as elements of other DOE programs. Therefore, they generally are not documented in this report. When returned surveys identified sources of total building energy-use data, this information was recorded in the data base. However, these sources of data are not extensively documented since they do not provide the desired end-use resolution.

\subsection{ORGANIZATION OF REPORT}

Section 2 of the report summarizes the inventory of existing sources of end-use data, and assesses the adequacy of these sources to serve research needs. Specific conclusions regarding the types of empirical data currently available are discussed, followed by an identification of significant gaps in the data. The section concludes with recommendations on the application of resources to meet program goals.

Section 3 describes the procedures used to conduct the inventory of enduse data and summarizes the results of the survey. This section contains brief summaries of past, current, and planned end-use data collection activities. Section 4 outlines the research issues that the data are intended to address and includes a description of the specific types of data sought. In addition to continuous measurements, these data include one-time tests and building performance factors. Both the identification of research needs and data requirements are based upon numerous discussions and meetings with professionals in the private and public sectors.

Section 5 describes the data base management systems for tracking the organizations and individuals contacted, and for tabulating the questionnaire results. All questionnaire responses were entered into the data base, even for 
data sources outside the scope of the project. This section is designed to assist in providing access to the full publicly-available data base.

Section 6 includes additional information on a limited set of the end-use metered data projects described in Section 3. This section provides end-use profiles for buildings in the domain of PNL's metering program.

The report includes four appendices:

- Appendix A contains the survey form and the material included with the survey.

- Appendix B contains a listing of the organizations and individuals contacted during the survey.

- Appendix C contains a listing of the announcements and advertisements used in conjunction with the metered data inventory.

- Appendix D contains a list of references to existing sources of enduse metered data. 


\subsection{SUMMARY AND CONCLUSIONS}

Pacific Northwest Laboratory conducted a comprehensive inventory of enduse metered data during the first half of FY84. The inventory did not discover many sources of metered end-use data; however, research into existing data bases and extensive discussions with professionals associated with building energy conservation have enabled a clear characterization to be developed of the types of metered data that are required to further energy conservation in commercial buildings. Based on the results of the inventory and this clarification of data requirements, the adequacy of existing data bases has been assessed, and recommendations have been developed for future federal data collection efforts.

A summary of sources of existing metered end-use data is provided in Section 2.1. The adequacy of this data for research needs is summarized in Section 2.2. Conclusions and recommendations for further data collection activities are summarized in Section 2.3.

\subsection{SUMMARY OF SURVEY FINDINGS}

There are two major findings of the survey: 1) that there are few we11documented sources of metered end-use data available in the public domain, and 2) that a we11-documented and widely available metered end-use data base would be of value to many professionals in building design, public utility management, and conservation research.

The majority of individuals contacted through the survey professed a desire for empirical end-use metered data that is accurate and well documented. Many of these individuals, however, are not aware of many (or even any) of the limited data sets already available, or know how to obtain them.

The survey revealed that there are numerous data bases that contain monthly summaries of total building energy consumption by fuel type, together with (usually) building audit data. These data are valuable for many uses, but they are clearly inadequate for other essential conservation activities that require evaluating detailed time-series relationships between building loads 
and energy consumption. The inventory project was initiated to focus upon sources of metered end-use data for commercial buildings with typical design practices (i.e., buildings that were not designed using high-technology and/or solar systems). The selection criteria require that consumption data be separated into minimum categories of HVAC, lighting, water heating, and process energy use, and be recorded on at least an hourly basis. An additional requirement established at the survey's inception is that the buildings metered must be typical buildings of the post-oil-embargo era that reasonably represent the nation's existing building stock. The final requirement is that the data need to be in the public domain. It should be noted that a number of research needs pertaining to end-use metered data, such as assessment of equipment efficiency, do not require data sets meeting all of the above criteria. In addition, metered data from buildings built prior to 1973 contain data valuable for a number of research activities.

The inventory uncovered few data sets that meet the established criteria. Data sets that meet these criteria are listed in Table 2.1 and are organized by building type. Table 2.1 also contains information about the types of supporting data collected in conjunction with the energy data. In some cases, it is not known when a building was built; a building is listed in the table if it may have been built after 1973.

The inventory uncovered data sets for 39 buildings: 8 large office buildings, 1 small office building, 11 restaurants, 8 hotels and motels, 4 large grocery stores, 2 retail stores, 2 hospitals, and 3 multifamily dwellings. The end-use data available for nine buildings metered by the California Energy Commission and six buildings metered by the Hospitality, Lodging and Travel Research Foundation, Inc. do not cover a whole year.

A very important source of metered end-use data is an effort currently underway by the Bonneville Power Administration to conduct end-use metering in 250 commercial buildings in the Pacific Northwest Region; these buildings have not all been metered yet, and are not included in the above table. A brief description of the project is provided in Appendix $E$. 
TABLE 2.1. Metered Data Projects Meeting Project Criteria

\begin{tabular}{|c|c|c|c|c|c|c|}
\hline Building Type & Project Name & $\begin{array}{l}\# \text { of } \\
\text { Bldg. }\end{array}$ & $\begin{array}{l}\text { End- } \\
\text { Use }\end{array}$ & $\begin{array}{l}\text { Equip. } \\
\text { Effic. }\end{array}$ & $\begin{array}{l}\text { Bldg. } \\
\text { Char. }\end{array}$ & $\begin{array}{l}\text { Micro } \\
\text { Climate } \\
\end{array}$ \\
\hline Large office & $\begin{array}{l}\text { Seattle City Light } \\
\text { Park Plaza } \\
\text { IBM/ASHRAE } \\
\text { Calif. Energy Commission } \\
\text { Ohio State Univ. } \\
\text { Standard Oil Co. }\end{array}$ & $\begin{array}{l}2 \\
1 \\
1 \\
2 \\
1 \\
1\end{array}$ & $\begin{array}{l}\star \\
\star \\
\star \\
\star \\
\star \\
\star\end{array}$ & $\begin{array}{l}\star \\
\star\end{array}$ & $\begin{array}{l}\star \\
\star \\
\star \\
\star \\
\star\end{array}$ & $\begin{array}{l}\star \\
\star \\
\star\end{array}$ \\
\hline Small Office & Sigma IV & 1 & * & * & * & * \\
\hline Restaurant & $\begin{array}{l}\text { NRA/Penn State } \\
\text { Jolly Tiger } \\
\text { Seattle City Light } \\
\text { Calif. Energy Commission }\end{array}$ & $\begin{array}{l}7 \\
1 \\
2 \\
1\end{array}$ & $\begin{array}{l}\star \\
\star \\
\star \\
\star\end{array}$ & $\begin{array}{l}\star \\
\star\end{array}$ & $\begin{array}{l}\star \\
\star \\
\star \\
\star\end{array}$ & $\begin{array}{l}\star \\
\star\end{array}$ \\
\hline Hotel & $\begin{array}{l}\text { American Hotel/Motel } \\
\text { Cal if. Energy Commission }\end{array}$ & $\begin{array}{l}6 \\
2\end{array}$ & * & * & * & * \\
\hline Large Grocery & $\begin{array}{l}\text { Cal if. Energy Commission } \\
\text { Seattle City Light }\end{array}$ & $\begin{array}{l}2 \\
2\end{array}$ & * & & * & \\
\hline Retail Store & Seattle City Light & 2 & * & & * & \\
\hline $\begin{array}{l}\text { Multi-Family } \\
\text { Residence }\end{array}$ & Seattle City Light & 3 & * & * & & \\
\hline Hospitals & Calif. Energy Commission & 2 & * & & & \\
\hline
\end{tabular}

\subsection{ASSESSMENT OF EXISTING DATA}

The inventory was conducted not only to identify existing data, but also to assess whether sufficient data already exist to meet the research needs defined by the Department of Energy. A detailed discussion of the uses of enduse empirical data and an analysis of the specific field measurements necessary to support these needs are presented in Section 4.0. The following assessment is based upon those uses and requirements.

A distinction among data uses requiring a large, less detailed sample is presented in section 4.0, where the data needs for six different areas of research are defined. These areas are: utility planning, building design, 
equipment design, energy management systems, public policy, and energy consumption simulation. The assessment of existing data is based upon its suitability to serve research topics requiring large numbers, "statistically-based research," and these requiring smal1 numbers, "operations-research-based data," of buildings.

\subsubsection{Assessment of Statistically-Based Research Data}

The existing set of metered building data is not sufficient to serve this use or purpose. The group of buildings identified in Table 2.1 would not serve as a suitable basis for a statistical study due to the small number of buildings in each category and the lack of a shared sampling methodology for their selection. One example of a statistically-based study is the study being started in the Northwest sponsored by the Bonneville Power Administration. Other successful assessments using this type of data may have already been completed by franchise/chain stores. However, these data, if they exist, do not appear to be in the public domain, and are not available to PNL.

\subsubsection{Assessment of Operations Research Based Data}

A number of uses for metered end-use data rely on a few buildings with detailed instrumentation and documentation. A detailed assessment of the quality, as well as the documentation, still must be completed for some of the data sets. However, a number of tentative conclusions have been made. The quality and quantity of metered data for three types of commercial buildings (restaurants, large office buildings, and hotels) appear to be sufficient for many of these types of research needs. A definitive assessment should be based on a detailed review of each data set by personnel conducting research and/or based on energy audits and retrofits for these building categories. In addition, many of the buildings in these three categories are currently being metered. It is assumed that those metering efforts will continue as planned and that documentation will be included. 
A brief review of the data available for the three building types follows.

1) The eleven restaurants metered include eight restaurants with detailed end-use data collection, supporting building data, and documentation. While the other three restaurants involve less detailed data collection, they appear to contain useful data.

2) The eight office buildings include two buildings with detailed data collection. While data sumaries for one of the buildings are publicly available, the unprocessed data may not be available. The other five buildings contain less detailed data collection and in some cases, data collected only over a short time period.

3) The sufficiency of the data on hotels and motels is the most uncertain of the three building types. While six of the hotels are welldocumented and involved collection of data in addition to energy consumption, the data was collected over 1 imited periods in the heating and cooling seasons. The other two buildings are not as well documented.

There is, of course, a great difference among the configuration and operations of various hotel, office and restaurant categories, and it is likely that the data are adequate for analyses of some of these categories, but not all.

\subsection{CONCLUSIONS}

Collection of end-use metered data is both desirable and valuable for many areas of building energy conservation research. Empirical data are needed to address many issues which to date have been addressed using only simulation techniques. The adequacy of using simulation techniques for various purposes needs to be assessed through comparison with measured data. While these data are expensive to acquire, it is cost-effective to do so in the long run, and the need is not being served by the private market.

The preceding conclusion is based on results from the inventory of existing data, which highlights two important facts. First, although the data are widely desired in the private sector, they are not widely available. Second, where suitable data are publicly available and contain the desired supporting 
information (such as microclimate and building construction and operation information provided in the form of usable documentation) their collection has generally been funded by government-sponsored research.

Based on the research conducted for this report, PNL recommends three options for further collection of end-use metered data. The options are not mutually exclusive, and ideally, all three would be pursued. The third option is given the lowest priority, however, since it would probably be the most costly and serve fewer of the research areas defined in this report than the first two options.

Option 1: Conduct detailed end-use metering and data collection for a small sample of buildings in categories other than restaurants, large office buildings, and hotels/motels. The data collection should include energy by end-use and building thermal zone, microclimate data, building construction data, building operations data, and equipment efficiency data. Specific measurement requirements are 1 isted in Section 4.2 .

Option 2: Review the identified end-use data for buildings in the restaurant, large office, and hotel/motel categories. The review should include a detailed assessment of the quality of these data sets and determine the cost of acquiring and analyzing the existing data. Acquired data should be reviewed, evaluated further, and be made available through a common distribution system.

Option 3: Collect building end-use data for a large sample of buildings. The building selection should be based on a statistical sampling designed to characterize end-use energy consumption in a single category of commercial buildings.

In addition, PNL recommends that DOE establish a government-sponsored data base of end-use metered data. The data should be reviewed and processed so it is publicly available in an easily-used and comparable format. 


\subsection{INVENTORY OF DATA BASES}

The following end-use data inventory is based upon a comprehensive search. Contacts were made with over 200 organizations, groups, and individuals identified as being likely to know of metering activities. In addition, a literature review through computerized library catalogs was conducted and advertisements and notices placed in trade and professional magazines. Approximately half of the contacts were made through a survey form distributed by mail. The rest of the responses were collected through telephone inquiry. While an effort was made to contact the "correct" individual in a particular organization, there is always the chance that the individual contacted did not know of all (or any) of the metering activities occurring within his/her organization.

\subsection{SURVEY METHODOLOGY}

The survey was designed to identify existing data sets and ongoing end-use metering studies. The initial assumption was that, since there probably were not many sources, the best strategy would be to design a simple questionnaire and use follow-up contacts to collect additional information about end-use metering projects identified by the initial survey.

The questionnaire was composed of three sections. The first section identified the name and address of the individual completing the survey. The second section solicited information about the respondent's interest in metered end-use data for commercial buildings. The third section asked for information about metering projects with which the respondent was familiar. The information collected included: 1) a project contact, 2) the location and type of building(s), 3) the type of data collected, 4) the metering technique used to collect the data, 5) the time resolution of the metered data, and 6) whether the data are in the public domain.

A copy of the questionnaire is provided in Appendix A. The survey was mailed with a cover letter describing the purpose of the survey and the scope of the metering program. In addition, a stamped and addressed return envelope was included. The return rate on the survey was approximately $25 \%$. 
The survey was initiated by telephone in many cases to ensure that the survey included the most promising organizations and individuals. The telephone interviews were conducted by James Heide11, Research Engineer, at PNL. Notes from all conversations were logged. The telephone-administered interview allowed a more comprehensive discussion of metering projects and contacts than could be achieved by mail.

The individuals contacted fell into five broad affiliation categories: government, national laboratory, trade and professional organization, utility, and private company. The names of the organizations and persons contacted are provided as Appendix B. In addition to the contacts listed in Appendix $B$, the one-page questionnaire was mailed to each of the 50 state energy offices.

\subsection{SUMMARY DESCRIPTION OF EXISTING DATA SETS}

In addition to the mail and telephone contacts, several other potential sources of information were explored. A literature review was conducted into a number of computerized indices. Detailed discussions were held with researchers at other DOE sponsored National Laboratories and with the Gas Research Institute, the American Gas. Association, and the Electric Power Research Institute. The results from these contacts as well as from other major sources of information are briefly described below.

Previous inventories of sources of metered data have not been limited to end-use data for commercial buildings, and typically have had a broader focus and objectives. Three previous inventories are discussed below and are listed in the bibliography in Appendix D. These inventories represent significant efforts to summarize sources of data useful for load forecasting and for characterizing total energy use in commercial buildings.

\subsubsection{Existing Surveys}

One inventory completed by XENERGY, Incorporated, in 1981, A Description of Building Energy Use Data Bases, (1) was prepared under contract to the National Institute of Building Sciences. This report was funded as part of a response to the Building Energy performance Standards (BEPS) legislation to help determine the extent to which existing buildings meet the design energy 
budget levels mandated by the regulations. The purpose of the report was to inventory sources of metered energy consumption data. The inventory includes sources of total energy consumption, data bases containing building energy audit information, and data bases containing energy consumption by fuel type and building characteristics information. The majority of the sources listed in the inventory are state energy offices and federal agencies. The inventory also includes references to data collected by utility trade organizations and a limited number of architectural and engineering firms.

Since the objective of the XENERGY survey was not to identify sources of end-use energy consumption, end-use sources were not highlighted. However, the few end-use sources that were documented and investigated are included in Section 3.3 .

Review of the XENERGY compilation suggested that there are numerous sources of end-use data on schools and hospitals collected by state energy offices. These sources were listed in the preliminary inventory mailed with the questionnaire in PNL's survey. Subsequent investigation, however, revealed that these "data" were developed through professional judgment and are based neither on metering nor computer simulation. Although all the energy offices were not contacted, it appears that the data were collected as one element of DOE's Institutional Buildings Grants Program.

DOE's Institutional Buildings Grants Program provides funded professional engineers to audit schools and hospitals and perform simple operation and maintenance type activities to reduce energy consumption. The engineer used utility bills and the audit to complete a form which includes an estimate of end-use energy consumption before and after implementation of the simple conservation measures. Institutions audited could apply for additional funds to complete energy conservation measures (ECMS) to further reduce energy consumption. The audit and fuel bill data were collected in a national computer network maintained by Oak Ridge National Laboratory. Reports documenting this project are listed in the appendix. (2) currently, there is no funding to support the data base and potential users. The latest data are currently three years old. 
A second inventory, An Annotated Compilation of The Sources of Information Related to Usage of Electricity in Non-Industrial Applications, was completed by the National Bureau of Standards in 1978. This report was compiled for the Department of Housing and Urban Development and contains hundreds of abstracts of documents related to electricity use and load research. The report includes data references for both residential and commercial buildings. A large number of projects are documented in which total energy use and demand were recorded on a sub-hourly basis, but there were no cases in which all end uses were metered concurrently in a commercial building. The report identifies projects where selected end-uses were metered. The latter group of projects are inventoried in Section 3.3.

The third inventory Load Data Pool Feasibility was sponsored by the Electric Power Research Institute (EPRI) one of the principal research organizations for electric utilities. (4) EPRI is presently sponsoring a research effort to inventory utility data that can be used for load forecasting research. Synergic Resources Corporation's (SRC) office in Seattle, WA, is conducted this research project. A meeting with Craig McDonald of Synergic Resources Corporation was held to determine which utilities in the U.S. had data bases of end-use metered data. The data commonly used in conjunction with load forecasting differs from the data their project requires since end-use energy consumption data are typically not collected, nor are other desirable data, including building operations, occupancy, and microclimate data. In addition, a large sample of buildings within a service area is usually required by utilities in order to extrapolate to the whole rate base. EPRI's extensive survey did not uncover any end-use metered data projects. However, it is possible that utilities that SRC contacted about the load forecasting data may not have mentioned individual projects relating to extensive monitoring, or were not aware of metering efforts conducted by other departments within their organization.

\subsubsection{New Surveys}

Architectural Energy Corporation (AEC) of Westminster Co. under contract to PNL, conducted a small telephone survey to identify existing sources of metered data. The principals at AEC, Michael Holtz and Donald Frey, have had 
extensive experience with end-use metering programs, primarily in passive and active solar buildings. Their survey included over 30 contacts and resulted in the discovery of (mainly) a number of passive solar monitoring efforts. While solar-related projects are not in the domain of the buildings being studied at PNL, the information is useful in coordinating the data collection with related data bases. These projects are included in the table in Section 3.3.

The objectives and the types of data desired for the PNL's end-use energy data base were discussed with individuals in other National Laboratories involved in related research. These laboratories include the Solar Energy Research Institute (SERI), Lawrence Berkeley Laboratory (LBL), Oak Ridge National Laboratory (ORNL), Argonne National Laboratory (ANL), Brookhaven National Laboratory (BNL), LOS Alamos Scientific Laboratory (LASL), and Rockwe11 International/Energy Technology Engineering Center (ETEC). LASL and SERI have both been involved with solar related metering efforts for commercial buildings. Lawrence Berkeley Laboratory maintains a building energy-use data base called Building Energy Compilation and Analysis (BECA). One element of the data base contains data specific to commercial buildings (BECAC).

Argonne National Laboratory has collected HVAC energy-use data for a special class of commercial buildings: buildings with cold-storage systems. A second effort involved collecting performance data on boilers in commercial buildings. Other energy end use data were not collected concurrently in either project. Oak Ridge National Laboratory and Argonne are currently working on a program called Commercial and Small Apartment Conservation Service (CACS). Commercial buildings analyzed in this program are typically less than 3000 square feet and use less than $48,000 \mathrm{~kW}$ of electricity per year. Over 390 buildings have been studied to date. Data collected include utility billing information and information from building audits; end-use data has not been collected. Computer simulations (using the model DOE-2) have been conducted for prototype buildings to assess the benefits of retrofit measures. Although air infiltration studies are currently planned, there are no plans for end-use energy metering. 
The Buildings Energy Compilation Analysis (BECA) data base contains data used to characterize the results of energy savings from energy conserving retrofit measures and new building design features. Building information in this data base includes: the size of the building; descriptions of the HVAC systems, building shell, and lighting systems; and a listing of energy conservation features and estimated energy savings from these features. BECA also includes estimates of end-use energy consumption based upon simulations. Actual energy use data are included in the data base, based upon utility billing records in most cases. End-use metered data is also sought. However, according to Jeff Harris at LBL, there are currently no empirical end-use data for commercial buildings in the data base disaggregated below a monthly basis. The BECA data base is not intended to include data on "typical buildings." The data base is focused instead upon data on energy-efficient buildings and buildings in which energy conservation retrofits have been instituted. The Gas Research Institute is currently conducting limited energy monitoring to determine the market potential for fuel cells. The project includes metering limited loads, usually HVAC, at 80 metering sites.

Another large data base of end-use metered data is currently being developed by Sierra Power Company in Reno, Nevada. The utility has started an extensive metering program in order to satisfy resource planning requirements. The purpose of the study is to develop end-use energy profiles of electric energy consumption for input into their load forecasting models. The metering plan calls for installation of metering equipment at 430 locations in the period of 1984 through the first quarter of 1986. The program involves metering of residential, commercial, and industrial facilities. A subset of the buildings will be incorporated in a program to test the effectiveness of conservation measures. A breakdown of the buildings to be metered are shown below in Table 3.1. Buildings metered in Phase I and II involved data collection for the building as is. Phase III refers to buildings where conservation measures will be tested.

The sites, selected through a survey, are designed to represent the building stock. The building metering plans are not necessarily designed to collect all sources of energy use in the buildings. Buildings in Phase $I$ and 
TABLE 3.1. Breakdown of Metering Sites for Sierra Pacific Study

\begin{tabular}{lccc}
\multicolumn{1}{c}{ Building Type } & \multicolumn{2}{c}{ Number of Buildings } \\
\cline { 1 - 1 } Shases I and II & 65 & Phase III \\
Multi-family residential & & 40 & 80 \\
Commercial & 105 & 22 \\
Offices & 32 & 34 \\
Food stores & 5 \\
Casinos & 13 & \\
Agriculture & 20 \\
Retail stores & 35 \\
Manufacturing & 15
\end{tabular}

II will involve collection of electric energy consumption only. In Phase III the residential program involves conversion of electric space heating to gas. If an electric to gas conversion is made, the gas used by the converted appliance will be measured. Other uses of gas in the structure will not be metered. A list of end-uses metered are shown in Table 3.1. The data will be collected and stored on a fifteen minute basis using a variety of metering equipment. Meteorological data will be obtained from NOAA weather stations plus measurements of wind speed and external temperature at a limited number of metering sites. The metering equipment used, including data loggers and power line carriers, will depend on the circuits being metered.

\subsubsection{Literature Survey}

A literature search for energy end-use data bases was conducted. The data bases for literature and newsletters included: Directory of Online Information Resources, Directory of Computerized Data Files, "Federal Statistics Users' Conference", U.S. DOE Energy Database, "FEDEX" an Energy Information Administration database, U.S. Forecasts, Trade and Industry Index, National Technical Information Service (NTIS), and Energy Research in Progress. The literature search did not provide many new leads. One problem is that projects referred to as "including end-use data" often can mean many different things. "End-use" is often used to describe energy use data separated by fuel type. Since the 
cost of metering tends to be relatively high, the data are usually based on either an engineering-based simulation model, or some combination of statistical extrapolations and simulations to yield typical end-use consumption for a class of buildings.

\subsubsection{Journal Notices}

In order to reach many of the architectural and engineering firms and HVAC equipment manufacturers who might have conducted metering efforts, requests to publish notices in several trade journals were made. The notices explained the effort to inventory sources of metered data and requested that individuals who have metered data that they are willing to share, or those interested in obtaining such data to contact PNL. The following magazines and newsletters were contacted and requested to publish the notice: Air Conditioning, Heating, and Refrigeration News, Progressive Architecture, ASHRAE News, Electrical World, and SERA Briefs. Paid advertisements were placed in the following journals and papers: ASHRAE Journal, Public Utilities Fortnightly, Building Design and Construction, and Energy Users News. Copies of the advertisements and notices are included in Appendix $C$.

\subsection{SURVEY RESULTS}

A summary of end-use metered data sets identified from the inventory is provided in Tables 3.2, 3.3, and 3.4. This survey is an ongoing effort and will be updated periodically during the course of PNL's Commercial Buildings Program.

Few of the data sets identified in the table and described below contain all the attributes desired for a comprehensive metering project. Each data set is unique in terms of the metered end-uses, the degree of aggregation, and the amount of supporting documentation. The diversity in the attributes of the data sets is as broad as the reasons for instituting such studies. The purposes for the studies range from demonstrating elements of passive solar design to testing strategies for reducing energy consumption associated with a specific piece of equipment or end-use. 
The following terms are often used in characterizations of the data on metered buildings: end-use, building characteristics data, building occupancy data, building operations data, microclimate data, and equipment performance data. Brief definitions are provided below and more detailed explanations are given in Section 4.2 of this report.

- Building characteristics data include details about the building's design, construction, and HVAC systems. This type of data includes information generally collected during detailed building energy audits.

- Building occupancy data include some type of records regarding the number of occupants and activity levels in the building by day and time-of-day during the metered period.

- Building operation data include records about the day-to-day operation of the building. This includes information about operation schedules for the HVAC equipment, building cleaning schedules, and window and door openings.

- Microclimate data include information on inside and outside air temperatures, humidity, wind speed, wind direction, and solar radiation.

- Equipment performance data include measurements of the input and output energy from HVAC equipment.

If a data set is referenced as having one of these data types, it does not ensure that all the measured parameters falling within that data type have been collected. A detailed assessment of each project may be conducted as phase III of the metered data inventory project.

Table 3.2, Description of Metering Projects, is a list of metering projects uncovered in PNL's survey. The list includes the project's name, the type of buildings metered, and the location of the project. Tables 3.3 and 3.4 provide additional information on the projects listed in Table 3.2. Table 3.3 describes projects which involve end-use metering, and Table 3.4 refers to total energy-use metering projects identified through PNL's survey. Total energy consumption metering typically has energy consumption separated by fuel use. Tables 3.3 and 3.4 summarize four attributes of each project: the type 


\section{Table 3.2. Description of Metering Projects}

\begin{tabular}{|c|c|}
\hline Ref. & Project Name \\
\hline 1 & Georgla Power Company \\
\hline 4 & Tishman Research \\
\hline 5 & Ashrae Research Project \\
\hline 6 & Dallas/Fort Worth Alrport \\
\hline 7 & Model Post Office \\
\hline 8 & Cold Water Storage \\
\hline 9 & Northern States Power \\
\hline 10 & General Service Secondary \\
\hline 11 & Arizona Public Service Company \\
\hline 12 & Model Post Office \\
\hline 13 & Pakota Nature Center \\
\hline 14 & Energy End-Use on Office Bldg. \\
\hline 16 & Mid-Atlantic Office \\
\hline 16 & Assorted Metering \\
\hline 24 & Standard Oil BIdg., Chicago \\
\hline 26 & ENERPLEX \\
\hline 43 & Houston Lighting \& Power Co. \\
\hline 54 & Midwest Federal Bullding \\
\hline 55 & ASHRAE Report/Ohio Statë \\
\hline 65 & CEC/Hittman Associates \\
\hline 67 & Daylighting/Lighting Demo. \\
\hline 71 & Norris Cotton Building \\
\hline 73 & Passive Solar Design Program \\
\hline 78 & Util. Rate for HVAC/DHW Circult \\
\hline 79 & CACS - Comm. \& Small Apar. Serv. \\
\hline 80 & Campus Utility Costs \\
\hline 81 & Gas Cogeneration \\
\hline 82 & Standard Oil Building \\
\hline 84 & State Building Energy Mangmt. \\
\hline 92 & National Solar Data Network \\
\hline 104 & Pepco Total Energy Use \\
\hline 106 & Arizona Energy Data System \\
\hline 107 & Institutional Conservation Pro. \\
\hline 109 & State Bullding Program \\
\hline 110 & Metro. Washington Councll Gover. \\
\hline 112 & Small Buis. Energy Effic. Prog. \\
\hline 113 & Institutional Conservat. Prog. \\
\hline 114 & Government Owned BIdgs. \\
\hline 115 & Energy Extension Service \\
\hline 116 & Granite State Energy Conservat. \\
\hline 117 & NPA/Penn State Restaurant Proj. \\
\hline 118 & SIgma IV Metering Project \\
\hline 163 & J.C. Penney Offlce Building \\
\hline 170 & Wichita Schools Energy Analysis \\
\hline 171 & Utility Research Data \\
\hline 172 & Load Forecasting Research \\
\hline 176 & Restaurant Energy Analys is \\
\hline 182 & Religious BIdg. Energy Use \\
\hline 186 & Church Prototype \\
\hline 187 & Utility Load Forecasting \\
\hline 192 & Alberta Education \\
\hline 194 & Grade School \& Univ. Metering \\
\hline 198 & Catalog Showrooms \\
\hline 199 & UTC Power Systems \\
\hline 203 & Cleveland Utillity Metering \\
\hline
\end{tabular}

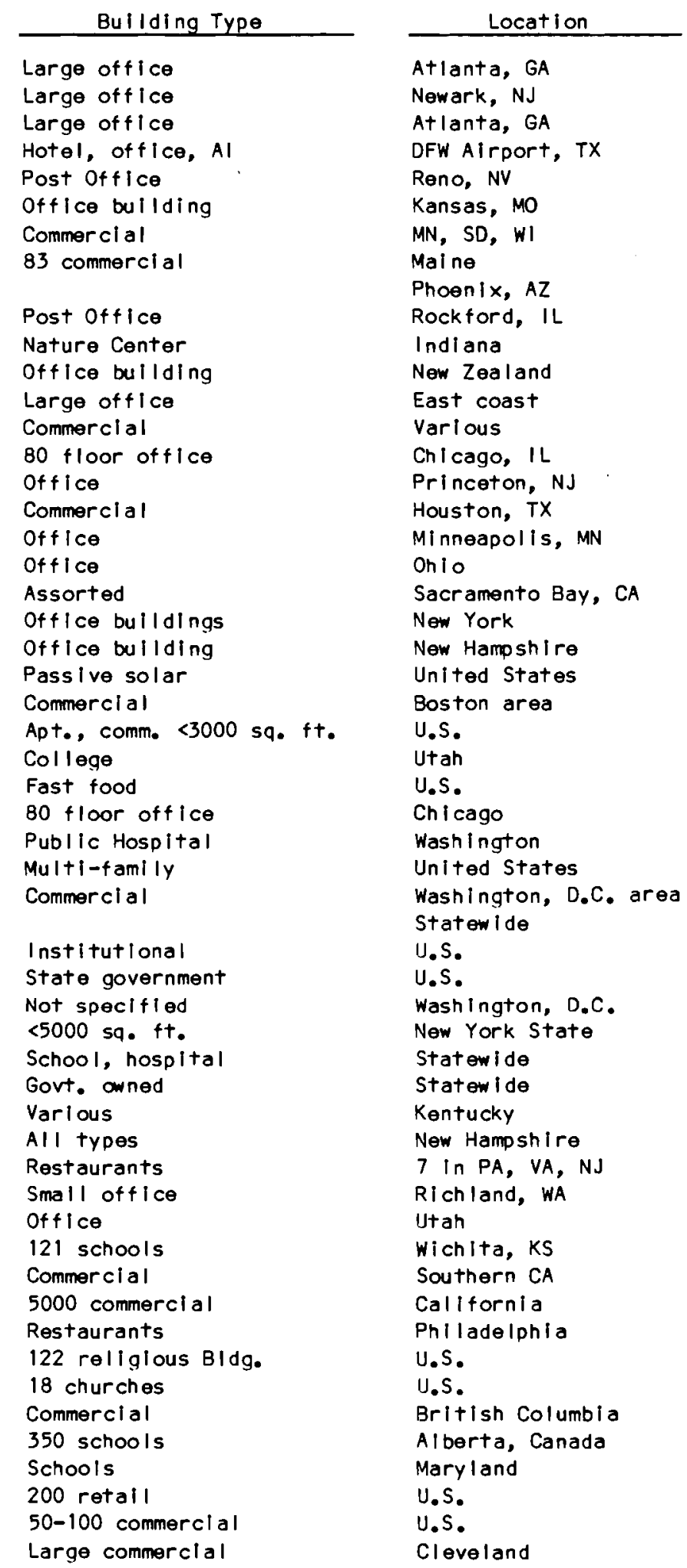




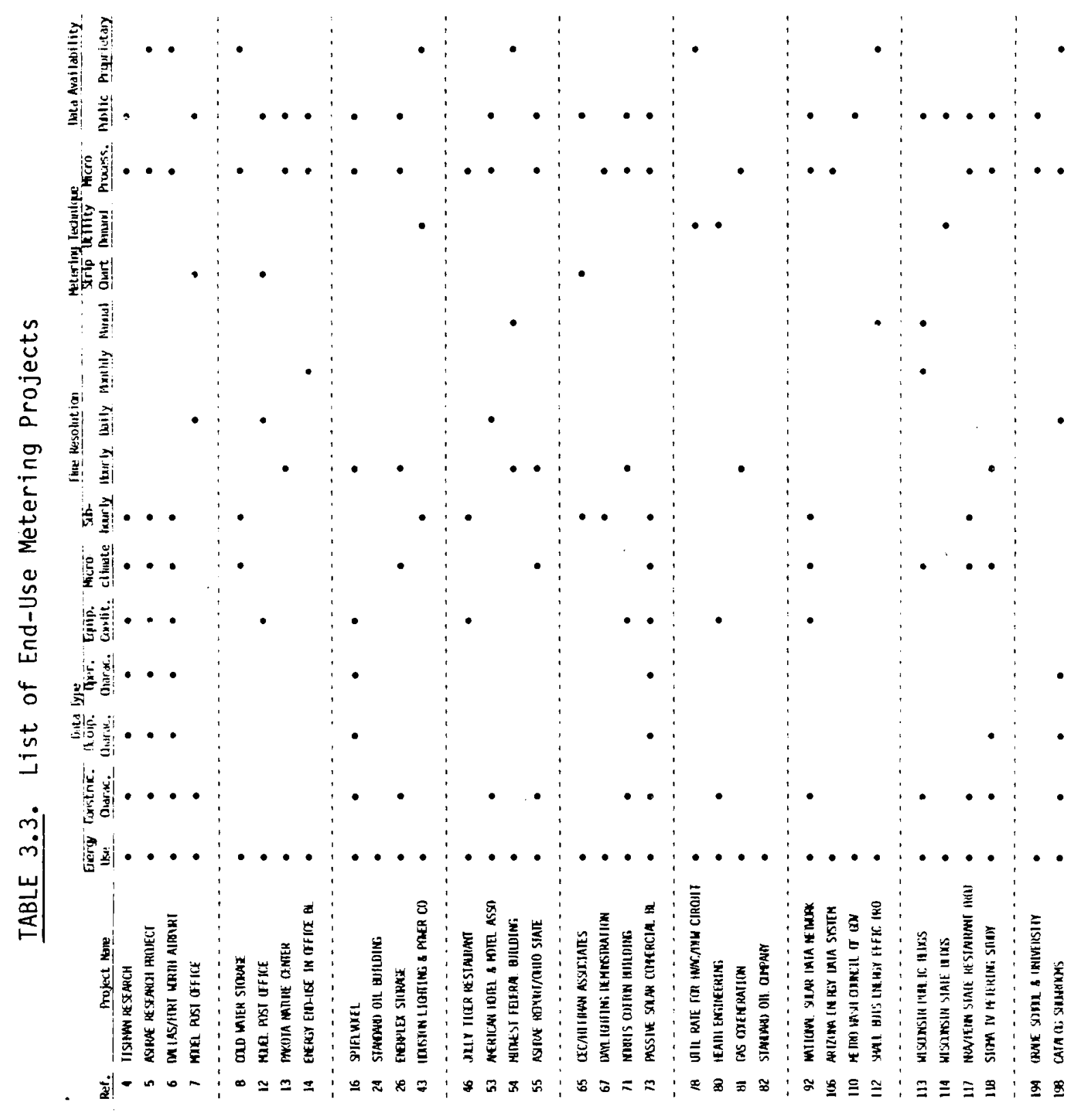




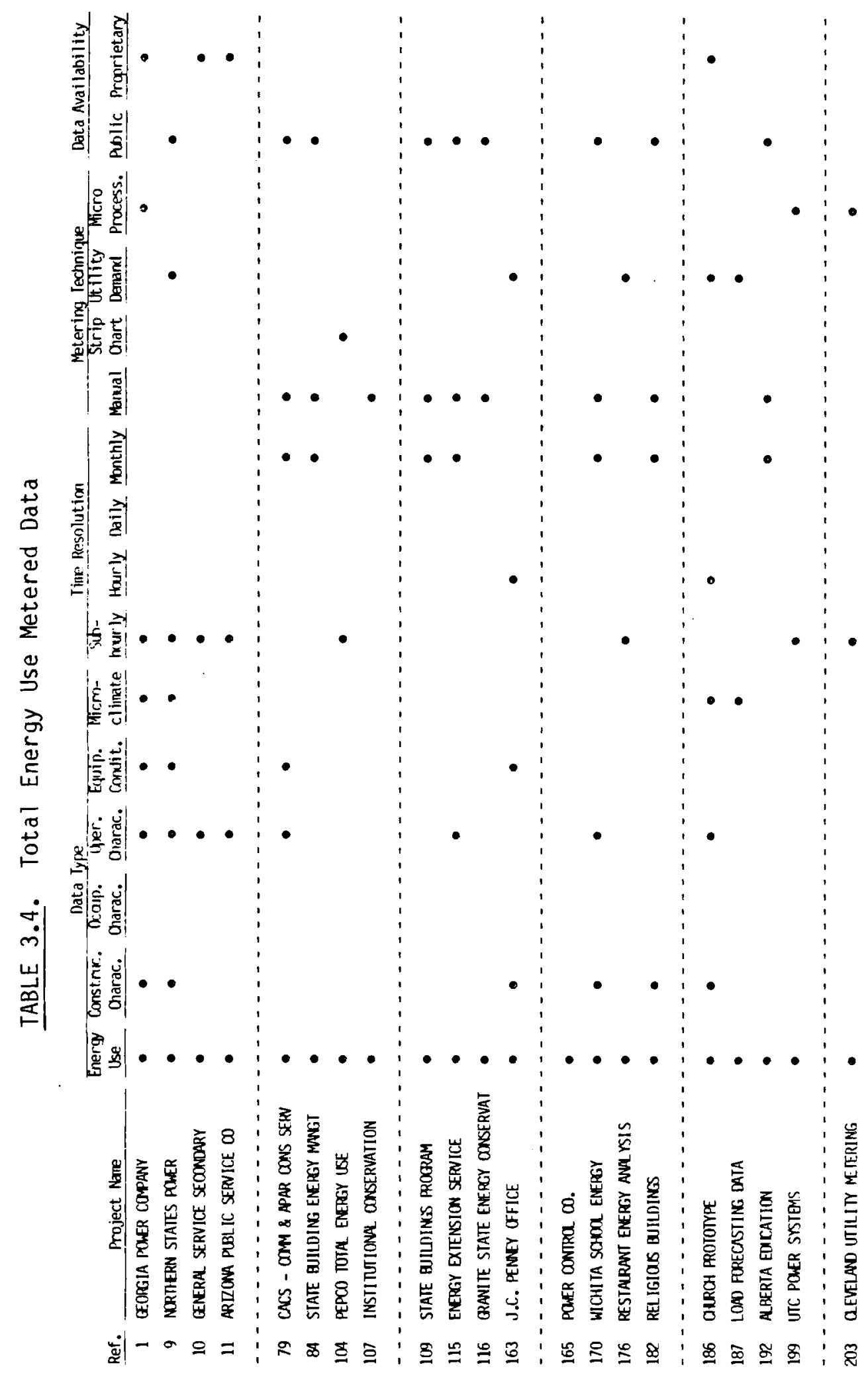


of data collected, the time resolution of the data collected, the method used to collect the data, and whether the data are in the private domain. A blank in the table indicates that the specific attribute has not yet been identified.

The time resolution of the metered data is characterized as having subhourly, hourly, daily, or monthly resolution. The metering techniques are divided into four categories: manual records, strip charts, utility demand meters, and microprocessors. Each data set is characterized as being in either the public domain, or as proprietary. The data set collected for each project is characterized by the level of supporting documentation. The types of supporting data are: building characteristics, building occupancy, building operation schedules and procedures, building microclimate, and equipment performance.

Several of the projects listed in Table 3.3 include metering of multiple buildings. Metering of multiple buildings occurred in projects $6,53,65,67$, 73, and 117. Projects that have collected, or are collecting, data potentially useful to the metering program are briefly characterized in this section. The following projects are organized by (first) listing projects involving multiple building types, followed by a listing of projects involving individual buildings or types of buildings. The latter group are further organized by building type.

\subsubsection{Multiple Building Projects}

Passive Solar Commercial Buildings Program

The Passive Solar Commercial Buildings Program is sponsored by the U.S. Department of Energy to evaluate the performance and conservation potential of passive solar design features. Currently, 11 of the 21 buildings in the program have been instrumented. Sub-hourly end-use energy consumption data along with equipment performance and microclimate data, are (will) being collected for a one-year period in each building. Data on building characteristics, building operation, and occupancy are also being collected. Each building owner in the program has selected his or her own DAS system, so there is a lack of uniform measurements and formatting of data among building types. A single DAS system was not used since hardware was not standardized at the time of the 
program's conception. However, the instrumentation and data formats of these buildings have been reviewed by Architectural Energy Corporation and improvements have been suggested to help ensure consistency in data collection among buildings. The program and the performance of some of the buildings have been documented in a number of reports prepared by Burt, Hi11, Kosar, Rittleman, Inc. One summary report describing each of the buildings is Passive Solar Commercial Building Program, Case Studies. (8) These data are in the public domain and will be made available through the American Institute of Architecture (AIA).

Seattle City Light

Seattle City Light is metering eleven commercial buildings within its service area. The building types include: two supermarkets, two retail stores, two office buildings, one full service restaurant, one fast-food restaurant, and three multifamily buildings. Hourly end-use energy consumption data are recorded with a microprocessor, and in some cases are supplemented by strip chart recorders. The number of channels monitored in each building ranges from 8 to 24 . The instrumentation assumes that power factors are constant, and the effective voltage and current are monitored to compute the average hourly consumption for all electrical channels. Equipment efficiency, occupancy, and microclimate data are not being collected. The buildings have been audited and potential conservation measures are being studied through detailed DOE 2.1 simulations. The associated weather data for the simulations are taken from the NOAA site at Seattle International Airport. This project is documented in the report titled Commercial Hourly End-Use Load Study. (9)

Bonneville Power Administration

The Bonneville Power Administration is starting an ambitious commercial buildings metering program in the Northwest, the End Use Load and Conservation Assessment Project. This program calls for the end-use metering of 250 commercial buildings distributed among the various categories of commercial buildings. The purpose of the study is to support research in load-forecasting and related areas to identify the potential for conservation as a resource to balance energy demand growth. Two hundred of the buildings will be within king County, the Seattle area. The other 50 buildings will be scattered throughout 
the BPA service area. Hourly end-use data will be collected along with building characteristics data. Each building will be audited and microclimate data will be collected at a subset of the 250 sites. The metering of these buildings is scheduled for 1984 through 1985. This project is being managed by Robert Stokes at PNL for the BPA offices of Conservation and Power Requirements. Currently the commercial buildings part of the project is in the pilot phase with an office building and grocery store metered since spring 1984 .

\subsubsection{Office Buildings}

Georgia Power Company Corporate Headquarters

The Georgia Power building is a large office building located in Atlanta, Georgia. This building is atypical since it was specially designed to conserve energy through load management, special energy conservation features, and an active solar collection system. Sub-hourly end-use data with supporting building operation and microclimate data are being collected for this building. Total energy use for the building is being monitored as well as selected HVAC equipment. Metered data from this building are currently being provided to DOE for the period of October, 1982 through October, 1984.

Park Plaza Building

The Park Plaza Building is a large office building located in Newark, New Jersey. This building was instrumented to evaluate control and energy management methods for office buildings, and is extensively monitored, with over 350 metering points. End-use, microclimate, and equipment performance data were collected at ten-minute intervals. In addition to the metered data, data on the building's characteristics and building operation are being collected. The data were collected over the period of July, 1982, through August, 1983, and the data are in the public domain. The project is sponsored by DOE and documented in a multi-volume report titled Design and Operational Energy Studies in a High Rise Office Building. (5) The monitoring was performed by Tishman Research for Bill Gerken at DOE.

IBM BUILDING/ASHRAE Research Project (RP321)

ASHRAE recently completed a metering study of a large office building in Atlanta, Georgia. Limited sub-hourly end-use data were collected along with 
data on building characteristics, building operations, microclimate, and equipment performance. The building was instrumented to study dynamic responses of buildings and improved control strategies in energy management control systems. While the data are collected using an automated procedure, it appears that not a11 the 15-minute data have been saved but rather have been summarized and saved in an aggregated format. Data are collected from 380 metering points with HVAC and lighting monitored as individual end-uses. These data were collected between January, 1982 and January, 1983. The data are considered proprietary, however, there will be a publicly available report.

IBM North Carolina

An IBM facility in Charlotte, North Carolina is being monitored in a project with similar objectives as the IBM/ASHRAE research project. Similar data are being collected (selected end uses, building operation, microclimate, etc) in a 1.5 million square-foot facility that contains both an office building and a manufacturing complex. Data are collected from 1200 metering points.

Dallas/Fort Worth Airport

Two small office buildings in the Dallas/Fort Worth airport are currently being metered in conjunction with the metering of the airport facilities. The two offices have 54,000 and 45,000 sq. ft., and are served by the central HVAC plant that delivers energy to the whole airport complex. Sub-hourly data are collected for some end uses along with equipment performance parameters. These data are proprietary. An article describing this project appeared in the ASHRAE Journal.

Kansas City Power and Light

Kansas City Power and Light is currently collecting heating and cooling end-use data for an office building in Kansas City, Missouri. The 100,000 sq. ft. building was instrumented to study the energy use associated with a cold water storage system designed to reduce peak air conditioning loads. Data are collected from 24 sensors that monitor HVAC efficiencies and energy use every two minutes. Limited microclimate data, including temperature and relative humidity, are also collected at two minute intervals. Associated information on building operations is also collected. This data set is proprietary. 
New Zeal and Office Building

Only limited documentation regarding this project has currently been uncovered. The office building project is reported to have collected typical energy use profiles for this type of building. End-use data are collected on a weekly basis.

Prudential Enerplex Buildings

The Prudential Enerplex Buildings represent atypical design features. The project consists of two buildings designed to be examples of energy efficiency in buildings. One building incorporates numerous passive solar design techniques, and the other building includes a unique component in its HVAC system: an ice storage system and earth cooling tubes. The building contains detailed instrumentation, with over 110 metered channels separating energy consumption by end use and collecting microclimate data. In addition, supporting documentation on building occupancy and characteristics is being collected. The data are likely to be available to Pacific Northwest Laboratory. This research has been extensively documented. Sources include a paper presented at the International Solar Energy Society in 1981.(5)

Midwest Federal Building

The Midwest Federal Building is located in Minneapolis, Minnesota. Enduse energy consumption was monitored as part of a demonstration project of Northern States Power Company starting in 1970. This building is atypical of common building practices in Minneapolis since it is all-electric. End-use energy consumption was initially being collected on a weekly basis from manual metering readings. Data was later collected on a monthly basis. Currently, data is not being collected. No additional supporting data were collected. The data are not readily available since the building has changed owners a number of times since 1970 and the project manager, Frances Anderson, from Northern States Power, has retired.

Ohio State University

A large office building at Ohio State was extensively instrumented prior to 1977. Hourly end-use and micro-climate data were collected over a one-year 
period along with supporting building characteristics and operations information. These data are in the public domain and are documented in a report titled ASHRAE Report, Energy Calculations For Load Profiles and Energy Requirements For Heating and Cooling of Buildings. (10)

\section{California Energy Commission}

The California Energy Commission sponsored an end-use energy metering project of nine buildings in the Sacramento and San Francisco Bay Area during 1978. The project was sponsored in conjunction with validating a commercial sector load forecasting model. Individual buildings were metered for a twomonth period. Two of the nine buildings were large office buildings. One building is $360,000 \mathrm{sq}$. ft. and 35 stories, and the second building is 850,000 sq. ft. and 37 stories. End-use energy consumption for 1 ighting, heating, cooling, water heating, and elevators was collected on 15-minute intervals. The data are documented in a report titled Development of a Data Base and Forecasting Model for Commercial Sector Electricity Usage and Demand, Volume IV. Norris Cotton Federal Building

The Norris Cotton Federal Building was specially designed for the General Services Administration to test a variety of energy conservation strategies. The building is highly "atypical" since each floor was designed with a unique combination of HVAC systems, lighting systems, and envelope specifications. Hourly end-use data were collected from over 700 sensors which measured end-use energy consumption, equipment efficiencies, and microclimate. Data were collected from September, 1979 to September, 1980. The data are available on magnetic tape from the National Bureau of Standards. This project is documented in the report Analysis of Data From the Energy Monitoring and Control System At the Norris Cotton Federal Building. (12)

\section{ERDA Daylighting Demonstration}

The New York State ERDA office has conducted limited end-use energy metering in office buildings. The purpose of the project was to test daylighting 
and lighting control strategies. Sub-hourly energy consumption data were collected for the lighting system and a few other end uses. The data have been collected using a microprocessor.

Standard 0il Building - Chicago

The Standard 0il Building in Chicago is an ASHRAE award winner for energy conservation for building retrofits. End-use energy consumption data have been collected for many years in this 80 story office building.

Air Conditioning Loads - Southern Cal ifornia

The Los Angeles Department of Water and Power has collected data on energy use of electric air conditioners in large office buildings for over ten years. Central systems of 500 tons or greater are monitored with 15 minute demand meters. This study is documented in Air Conditioning, Heating and Ventilating in the October, 1967 issue. Recently Southern California Edison collected similar data in a program to test automatic cycling of air conditioning equipment during high utility load periods. In this study total electric energy use and air conditioning loads were metered for 40 buildings with total loads ranging from $20-500 \mathrm{~kW}$. These buildings were selected from a statistical sample of 245 buildings where 15 minute total electric consumption was recorded. The data were recorded on magnetic tape recorders. Temperature data were collected on 15 minute intervals from nearby weather stations.

Mid-Atlantic Office Building

Partial end-use metering of a large high-rise office building was completed in 1981 by Larry Spielvogel, P. E. Electricity use on 26 floors of the building was metered, with four meters per floor. Two meters per floor measured HVAC energy use in the two interior zones. The two zones divided the interior floor space in half. Each of the other two meters measured electricity consumption for under-the-window heat pumps, lighting, and all other electricity used by the tenants for one-half of each floor's area. Meters used to measure purchased steam to heat the building and all other building electricity meters were read monthly. All auxiliary HVAC equipment, water heating equipment, and lighting were measured or estimated to determine average connected load. While no micro-climate measurements were taken, local weather data are 
available from an airport six miles away. Documentation of this project appears in the ASHRAE Journal, November, 1982. (13)

Utah Campus Utility Costs

Limited end-use metering at two state universities and one state college was conducted in Utah around 1972. The separation of end-uses was limited to heating energy, cooling energy, domestic water consumption, electricity for mechanical systems and lighting, and total electrical energy. Building use, building systems, and limited occupancy data were also collected. The data were collected using flow and electric demand meters in conjunction with recorders. The time resolution of the data has not been determined. The study was conducted by Heath Engineering Company and described in an article titled "Campus Utility Costs" appearing in the November, 1973 issue of Heating, Piping and Air Conditioning.

Sigma IV, Pacific Northwest Laboratory

Pacific Northwest Laboratory is currently metering a one-story, 20,000square-foot, office building in Richland, Washington. The building is being metered as one element in the Commercial Buildings Metering and Data Base Development Project. Low-cost sensors and data-acquisition systems developed at PNL are being tested in the building. Data collection, which began in February 1983, includes end-use energy consumption by building zone, microclimate data, and building characteristics and operation data. The data are collected by a microprocessor and are recorded on an hourly basis for all sensors based upon 1800 measurements per hour. The data are in the public domain and are available from Richard Mazzucchi or James Heidell from PNL's Economic Systems Analysis Section.

\subsubsection{Restaurants}

National Restaurant Association/Penn State

Seven restaurants are currently being metered by Pennsylvania State University in conjunction with the National Restaurant Association and Pacific Northwest Laboratory. End-use energy consumption data and microclimate data 
are being collected at fifteen-minute intervals. Building characteristics data and meal counts are also being collected. Data will be collected for a oneyear period from July 1983 to July 1984. The data are being collected under a U.S. DOE contract and the data will be in the public domain. The data will be available from Pacific Northwest Laboratory. This project is documented in the report Project on Restaurant Energy Performance. (14)

Jolly Tiger Restaurant

The Jolly Tiger Restaurant is a $4500 \mathrm{sq}$. ft. restaurant in Colonie, N.Y. The restaurant was metered to study the potential for energy conservation through retrofit measures. The restaurant is a family-style restaurant open 24 hours a day. The restaurant was extensively metered during the period of 1977 through 1978. End-use metered data along with microclimate, equipment performance, and peak demand were measured from 250 metered points every two minutes. The data were recorded on a hourly basis. In addition, building characteristics and building operations data were collected. The data from the project are in the public domain and the metering effort is extensively documented in a report titled Jolly Tiger Restaurant/Colonie, New York Energy Conservation And Heat Reclamation Project. (15) The metering and data analysis were performed by the Atmospheric Sciences Research Center at the State University of New York, Albany and W. S. Fleming and Associates.

Gas Cogeneration/McDonald

The McDonald's Corporation and the Gas Research Institute jointly plan to instrument a McDonald's restaurant to study a gas cogeneration facility. Hourly end-use energy consumption data will be recorded for the components of the HVAC system. Total energy use by fuel type will be recorded on a hourly basis. The project started in 1984 and data will be collected for 18 months. McDonald's Restaurants

The McDonald's Corporation has conducted end-use metering studies for some of its facilities. This data are proprietary and no details about this study are available. 


\subsubsection{Hotels and Motels}

American Hotel and Motel Association

End-use energy consumption in six hotels and motels was studied in a project sponsored by the U.S. DOE in conjunction with the American Hotel and Motel Association and the Lodging and Travel Research Foundation. End-use metering took place in six hotels located in Vermont, Minnesota, Arizona, Georgia, and Texas in 1980 and 1981. The buildings selected are considered typical and do not have special energy-efficient design features. End-use and microclimate data were collected on an hourly basis along with information about building characteristics, occupancy, and equipment performance. There were significant problems with sensors and the data logger, and thus there is a limited amount of data. There are approximately one month's worth of data for the heating and the cooling seasons in summer and winter for each building. The data are in the public domain. The study is documented in one summary report, summary Report of Energy Usage/Consumption Analysis for Six Hotels/Motels, $(16)$ and in a detailed document per building.

Dallas/Fort Worth Airport

Limited end-use data is being collected for a hotel within the complex. The characteristics of the hotel data set are the same as for the office facility, and more details are included in the office building section of the report.

\subsubsection{Miscellaneous Projects}

Model Post Offices

The Postal Service is currently conducting a Model Post Office program. The purpose is to study the energy impacts of various conservation measures. Five post offices around the country are, or will be, metered for end-use energy consumption data both before and after the installation of retrofit measures. End-use consumption for HVAC, lighting, hot water, and miscellaneous consumption will be recorded with strip chart recorders on a daily basis. Information on occupancy and microclimate will not be recorded. The program is managed in the different postal regions and is coordinated by Joel Liscomb in the U.S. Postal Service office in Washington, D.C. 
Commercial Building Space Heating Loads

Pennsylvania Power and Light Company, metered space heating energy use in 49 buildings between October, 1966 and September, 1967. The buildings were selected from a sample of 765 customers and included offices, retail stores, churches, schools, lodging, warehouses, banks, and restaurants. The study was conducted on buildings using a separate utility rate and meter for heating, cooling, and water heating. It was assumed that no air conditioning was used during the months for which data are reported: water heating energy use was measured and subtracted from total energy use. 


\subsection{DATA REQUIRED FOR RESEARCH OBJECTIVES}

The primary objectives of the metered end-use energy survey were to determine 1) how much data already exists and where it is stored, and 2) whether there are sufficient amounts of data to support research on energy conservation in commercial buildings. The first objective, identification of existing data, was met in Section 3. Accomplishment of the second objective requires developing a framework for interpreting the results of the survey. That framework is developed in this section.

It is impractical to design a data collection program that can provide all data needed to support research on energy conservation in buildings. On the other hand, it is possible to collect data which has 1 imited value for all potential users of empirical end-use data. Therefore, to ensure that useful data are collected, it is necessary to define the intended uses of the data, and clearly identify what data are needed. Section 4.1 outlines the major uses envisioned for the metered data and Section 4.2 identifies the data needed to serve those uses.

Section 4.3 addresses ways to reduce the data collected to ensure that the data are usable. These measures, referred to as performance factors, are used to analyze the data collected from single building and to make comparisons between buildings.

\subsection{SUMMARY OF DATA USERS}

The potential data needs of six areas of research were identified. These research areas are: utility planning, building design, building equipment, building energy control systems, public policy, and building energy use simulation techniques. While each research area has unique data needs, the data requirements typically fall into two categories. The first category is defined as "operations-research-based data." The data collection effort typically requires a few sets of detailed data on all aspects of the building including energy consumption, building construction, and building operation. The second type, "statistically-based research data," typically require large amounts of 
reduced data, such as one time tests of equipment efficiency and monthly enduse energy consumption, to use in statistical analyses.

The division of data requirements into two categories is somewhat arbitrary, but is useful for defining data needs. A metering effort inevitably includes a quantitative and qualitative tradeoff between detailed data collection from a few buildings or settling for less data from a larger number of buildings. In order to focus on the data needs of the six areas of research, the data requirements have been divided into operations-research type data and statistically-based research data.

\subsubsection{Operations-Research-Based Data}

Six areas of research and topics for which a few sets of well-documented data would be valuable are highlighted in Table 4.1. Many of the research topics are of interest to several research areas. This is inevitable since all the areas have reduction of energy consumption as the main objective. The data needs for each of these research areas are briefly outlined below. The descriptions are intended to provide the nexus between research needs and identification of the detailed measurements that need to be conducted.

Utility-related research primarily relies on "statistically-based data," however, limited empirical data sets may be of value in identifying demand and energy use profiles for building equipment such as lighting and HVAC systems.

TABLE 4.1. Uses of Detailed Data

\begin{tabular}{|c|c|}
\hline Area of Research & Research Topics \\
\hline Utility planning & Equipment testing, load management \\
\hline Building design & Analysis of energy use by subsystems \\
\hline Equipment development & Field performance of test designs \\
\hline Control strategies & Identification and testing of strategies \\
\hline Public policy & $\begin{array}{l}\text { Identification of potential conservation } \\
\text { measures }\end{array}$ \\
\hline Simulation techniques & Calibrated simulation, empirical techni \\
\hline
\end{tabular}


This information could be used in the technology component of load forecasting models. In this context, 15-minute peak demand and energy consumption data aggregated on at least a daily basis are probably sufficient.

A detailed analysis summarizing how energy is used by the building subsystems and the relationships between the subsystems would be useful for identifying building design strategies. The information could also be used to provide an indication of which design features would be most effective for reducing energy consumption. These research topics require collection of data by end use as well as detailed information about the building's construction. Information on building operations and occupancy are desirable in order to identify how the building is used, and to identify how occupancy behavior affects energy consumption.

Equipment developers are typically interested in detailed data on the field performance of specific pieces of equipment rather than consumption by end use. These types of data include energy demand characteristics, energy consumption, hours of operation, and cycling characteristics. Since it is difficult to measure the dynamic field characteristics of materials, the equipment of interest are typically HVAC and process equipment. Performance characteristics of process and HVAC equipment are often desired to have been recorded on a hourly or sub-hourly basis.

Data needs of public policy developers are similar to these of utilities and equipment designers. End-use metered data can be used to identify building subsystems to target for research and development projects, and equipmentspecific data can be used to identify specific research areas.

The market for energy management systems is growing, and it is becoming increasingly cost-effective to install these systems in small buildings as well as large ones. Detailed data collection efforts that include energy demand and consumption as well as the on-off status, flow rates, and temperature characteristics of HVAC equipment can be used to identify energy management strategies. This data typically needs to be collected frequently, such as every 15-minutes. Daily, or more aggregated, end-use data summaries have limited 
value in developing control strategies. It is desirable to study control strategies concurrently with metering in order to test the strategies developed.

Traditionally, researchers working on simulation techniques have been major users of end-use metered data. These simulation techniques are used in all of the forementioned areas of research. Limited sets of data have two major uses: to establish confidence in the predictive ability of models, and assess the ability of models to accurately predict the changes in energy consumption resulting from tests of various conservation measures.

The term "establish confidence" is used instead of "verify" since it is unclear how a few data sets can be used to prove that individual equations of the models, which are typically based on the principles of thermodynamics, are correct. Simply stated, there are more variables than data points, and it is difficult to distinguish between inaccuracies in the equations, and inaccuracies in the procedures and assumptions used to model the building. However, the ability of a model to track end use energy consumption over time can be assessed, and can be a valuable exercise to establish user confidence in a mode1. Data requirements for this area of research typically include climatological data, details on building construction, building equipment sizes and efficiency ratings, information on building operation and occupancy schedules, and end-use energy consumption aggregated to at least a daily basis.

A major use of simulation techniques is in determining the conservation potential of different design strategies, retrofit conservation measures, and the effect of selection of building equipment on energy consumption. In these cases, the user is interested in the accuracy of the estimates of the changes in energy consumption, rather than the accuracy of the estimates of total energy consumed. Research activities include adjusting or calibrating the simulation model until the model accurately simulates actual energy consumption. There is no predefined agreement as to what constitutes accuracy, or whether the comparison between estimated and actual energy use should be for the whole building, by end-use, or for each major piece of equipment, and, finally, the time resolution involved. Typically, only a few metered data sets are required for this research, since the procedures are time-consuming. In 
addition, the analyst is interested in concurrently modeling the building and either changing the operation strategies of the building, or having conservation measures instituted. The data requirements for this research are similar to those described for model testing.

An area of research that is gaining attention is the use of detailed metered data to develop empirical models that estimate energy consumption based on a set of driving functions, such as insolation or process loads. The proposed techniques involve determining the dynamic flow of energy in a building using a limited set of data, and attempting to extrapolate energy consumption based on the model developed. The attraction of this approach is that the estimation is based on thermodynamic principles of conductance, capacitance, and interzone coupling rather than on a pure statistical model. Thus the resulting model can directly estimate energy use from measurable physical quantities.

\subsubsection{Statistically-Based Data}

This section reviews areas of research that characteristically rely on large amounts of summary data rather than on hourly or sub-hourly data or in detailed equipment operations and microclimate data. The techniques used to summarize collected data are important since the data user is typically interested in available summaries. The definition of performance factors is important in establishing data reduction procedures. Potential research topics for the six areas of buildings research are shown in Table 4.2 .

\section{TABLE 4.2. Uses of Statistical Data Collection Efforts}

\begin{tabular}{lll}
\multicolumn{1}{c}{ Area of Research } & & \multicolumn{1}{c}{ Research Topics } \\
\cline { 1 - 1 } Utility planning & & Load research \\
Building design & & End-use consumption profiles \\
Equipment development & Market assessment \\
Control strategies & Market assessment \\
Public policy & Building standards, benchmark policies \\
Simulation techniques & Statistical techniques, normalized measures
\end{tabular}


Utilities have traditionally been the major collectors of energy consumption data on commercial buildings. The data requirements typically include large sample sizes so that the results can be statistically extrapolated to the rate base. Due to the cost of collecting end-use energy consumption data, these efforts are almost always concentrated on collecting total energy use over periods ranging from 15 minutes to a month. Prior studies of limited end uses often concentrate on water heating, space heating, or space cooling, or lighting. The information can be used in conjunction with developing programs to promote conservation, to reduce peak demand, or sel1 new equipment and services. Sub-hourly data is frequently used in conjunction with load forecasting studies. Data that would be useful to support utility research include end-use summaries on a daily or monthly basis, and information on building construction and operations which are typically collected in a comprehensive audit.

A statistical base for developing end-use energy consumption profiles based upon building characteristics and region of the country would be useful for building designers. These profiles could be used to develop energy-efficient design guidelines. Currently, end-use consumption guidelines rely on computer simulation and a variety of other estimation techniques.

Information on the general energy use characteristics for a large number of buildings is useful to equipment manufacturers and control system designers in understanding and identifying potential markets. This is important since private research and development (R\&D) assessments are made only after a profitable market for the development can be assured.

Large sample end-use data could be used to help develop public policy. One example is establishing a benchmark for energy consumption in currently designed buildings. The benchmark can also be used to provide technical support in developing building energy performance guidelines and standards, utility rate structures, and implementation of energy conservation measures.

Development of building simulation techniques relates to the three previously discussed areas of research. Utilities, building designers, and public policy-makers are interested in developing statistically-based models that 
account for the measured variations in total energy use and predicted variations in end-use energy consumption. In addition to using the data in statistical models, the data can also be reduced to develop normalized measures for assessing a building's energy performance. Normalized measures consist of data summaries using units of measure that allow comparisons with other buildings. One simple example is average end-use energy consumption per square foot.

\subsection{DATA REQUIRED TO ADDRESS RESEARCH NEEDS}

This section summarizes the data required to address the six areas of research reviewed in Section 4.1. This summary of the types of measurements, the importance of the data, and the costs of collecting the data, serves two purposes. The first purpose is to provide a set of criteria that can be used to measure the usefulness of existing metered data. The second purpose is to document the guidelines and rationale for the selection of measurements for federal metering efforts.

\subsubsection{Research Data Requirements}

PNL conducted discussions with potential and existing users of metered end-use data to determine the types of data needed to better understand building energy performance. These discussions were conducted at a technical advisory group meeting held in Washington, D.C. in June, 1983, and through phone conversations accompanying the inventory of existing end-use metered data.

The desired data have been broadly grouped into eight categories: microclimate, end-use energy consumption, shell construction, equipment characteristics, occupancy, building operating conditions, site descriptions, and assessment of energy conservation measures. The relative importance of these eight categories in supporting the six defined areas of research is characterized in the matrix in Table 4.3. The ratings are based upon professional judgment and consider the availability of existing data and the value of collecting the data given cost constraints. Each cell in the matrix is ranked on a scale of 1 - 3, where a " 1 " represents an essential data collection activity, "2" represents a desirable data collection activity, and " 3 " represents a non-useful activity. 
TABLE 4.3. Ranking of Research Areas

\begin{tabular}{|c|c|c|c|c|c|c|}
\hline & $\begin{array}{l}\text { Utility } \\
\text { Planning } \\
\end{array}$ & $\begin{array}{l}\text { Building } \\
\text { Design } \\
\end{array}$ & $\begin{array}{l}\text { Building } \\
\text { Modeling } \\
\end{array}$ & $\begin{array}{l}\text { Equipment } \\
\text { Developing } \\
\end{array}$ & $\begin{array}{l}\text { Energy } \\
\text { Control } \\
\end{array}$ & $\begin{array}{l}\text { Public } \\
\text { Policy } \\
\end{array}$ \\
\hline Climate & 2 & 2 & 1 & 2 & 3 & 2 \\
\hline Energy Use & 1 & 2 & 1 & 1 & 2 & 2 \\
\hline Shell Cons. & 2 & 2 & 1 & 2 & 2 & 2 \\
\hline $\begin{array}{l}\text { Equipment } \\
\text { Characteristics }\end{array}$ & 2 & 2 & 1 & 1 & 1 & 2 \\
\hline Occupancy & 2 & 2 & 1 & 2 & 2 & 2 \\
\hline $\begin{array}{l}\text { BIdg. Operation } \\
\text { Site }\end{array}$ & 3 & 1 & 2 & 2 & 3 & 2 \\
\hline Cons. Measures & 2 & 1 & 3 & 2 & 2 & 1 \\
\hline
\end{tabular}

1. Essential. 2. Desirable. 3. Not Useful.

If equal weights are given to each of the 6 areas of research, then the overall priorities for data collection, from most to least important, are as follows: energy use, building operating conditions, equipment characteristics, shell construction, assessment of energy conservation measures, climate, occupancy, and site description. It is important to recognize that the value of each data type is enhanced as other data become available, and that the value of a complete data set exceeds the sum of the individual components. In addition, it may not be appropriate to assign equal weights, since a program may emphasize detailed analysis of a few buildings versus a less detailed approach for a large sample of buildings.

The type and frequency of field measurements proposed for supporting the six research areas are defined in Table 4.4. Table 4.4 is designed to serve as the guide for the Commercial Building metering program in evaluating the adequacy of existing metered end-use data and in defining measurements for any future data collection activities. Once the priorities for research areas have been determined, the recommended field data measurements can be identified by looking under the appropriate column headings in Table 4.4.

Five approaches for collecting each data type (the row headings in Table 4.4) were considered. These approaches are listed below along with the 
TABLE 4.4. Guide to the Commercial Building Metering Program

\begin{tabular}{|c|c|c|c|c|c|c|}
\hline Measurement & $\begin{array}{l}\text { Public } \\
\text { Policy }\end{array}$ & $\begin{array}{l}\text { Building } \\
\text { Designers }\end{array}$ & $\begin{array}{l}\text { Bullding } \\
\text { Researchers }\end{array}$ & $\begin{array}{l}\text { Equipment } \\
\text { Develop. }\end{array}$ & $\begin{array}{l}\text { Control } \\
\text { Strategy } \\
\end{array}$ & Utilities \\
\hline \multicolumn{7}{|l|}{ MICROCL I MATE } \\
\hline $\begin{array}{l}\text { total horiz. insolation } \\
\text { diffuse horiz. insolation } \\
\text { dry bulb temperature } \\
\text { relative humidity } \\
\text { wind speed } \\
\text { wind direction } \\
\text { ground temperature } \\
\text { total insolation } \\
\text { water temperature }\end{array}$ & & & $\begin{array}{l}C \\
C \\
C \\
C \\
C \\
R \\
C\end{array}$ & C & & $\begin{array}{l}C \\
0 \\
c\end{array}$ \\
\hline \multicolumn{7}{|l|}{ ENERGY USE } \\
\hline $\begin{array}{l}\text { heating } \\
\text { coolling } \\
\text { ventilation } \\
\text { domestic hot water } \\
\text { misc fans, pumps } \\
\text { lighting } \\
\text { major appliances/equipment } \\
\text { misc. }\end{array}$ & $\begin{array}{l}c \\
C \\
C \\
c \\
C \\
C \\
C \\
C\end{array}$ & $\begin{array}{l}c \\
C \\
C \\
C \\
C \\
C \\
C \\
C\end{array}$ & $\begin{array}{l}c \\
c \\
c \\
c \\
c \\
c \\
c \\
c\end{array}$ & $\begin{array}{l}c \\
C \\
C \\
c \\
C \\
c \\
c \\
c\end{array}$ & $\begin{array}{l}c \\
C \\
C \\
C \\
C \\
c \\
C \\
C\end{array}$ & $\begin{array}{l}c \\
c \\
c \\
c \\
c \\
c \\
c \\
c\end{array}$ \\
\hline \multicolumn{7}{|l|}{ ENERGY DEMAND } \\
\hline $\begin{array}{l}\text { total demand } \\
\text { by end-use }\end{array}$ & $\begin{array}{l}\mathrm{C} \\
\mathrm{C}\end{array}$ & $\begin{array}{l}\mathrm{C} \\
\mathrm{C}\end{array}$ & $\begin{array}{l}c \\
C\end{array}$ & $\begin{array}{l}c \\
c\end{array}$ & $\begin{array}{l}c \\
c\end{array}$ & $\begin{array}{l}c \\
c\end{array}$ \\
\hline
\end{tabular}

EQUIPMENT

HEATING/COOLING BY ZONE

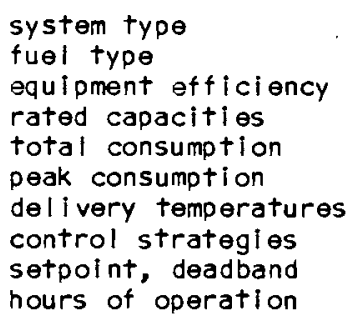

$\begin{array}{ll}\text { A } & \text { A } \\ \text { A } & \text { A } \\ \text { O } & 0 \\ \text { A } & \text { A } \\ \text { C } & \text { C } \\ \text { C } & C \\ \text { R } & \text { R } \\ \text { O } & 0 \\ \text { R } & \text { R } \\ \text { R } & \text { R }\end{array}$

$A$
$A$
$O / C$
$A$
$C$
$C$
$C$
$C$
$R$
$R$

A
A
C
A
C
C
C
C
R
R

$\begin{array}{ll}A & A \\ A & A \\ C & O \\ A & A \\ C & C \\ C & C \\ C & R \\ C & O \\ R & R \\ R & R\end{array}$

PROCESS

$$
\text { computers }
$$

elavators

MICROCL IMATE

flow

temperature (in \& out)

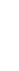

LIGHTING 
TABLE 4.4. (contd)

Measurement

$\begin{array}{llll}\text { Public } & \text { Bullding } \\ \text { Policy } & \begin{array}{c}\text { Building } \\ \text { Designers }\end{array} & \begin{array}{l}\text { Equipment } \\ \text { Researchers }\end{array}\end{array}$

BUILDING SHELL

\begin{tabular}{|c|c|c|c|c|c|c|}
\hline component UA & $\begin{array}{l}0 \\
A\end{array}$ & 0 & $\stackrel{0}{A}$ & 0 & $\begin{array}{l}0 \\
A\end{array}$ & O \\
\hline $\begin{array}{l}\text { window area/location } \\
\text { window transmittance }\end{array}$ & $\hat{A}$ & A & $\hat{A}$ & $\hat{A}$ & $\begin{array}{l}\text { A } \\
A\end{array}$ & $\hat{A}$ \\
\hline window absorbance & A & A & $A$ & A & A & A \\
\hline capacitance & 0 & 0 & 0 & 0 & 0 & 0 \\
\hline infiltration rate & 0 & 0 & C & 0 & 0 & 0 \\
\hline $\begin{array}{l}\text { bullding heat loss coef. } \\
\text { door/window operation } \\
\text { window covers }\end{array}$ & 0 & 0 & $\begin{array}{l}0 \\
\mathrm{C} \\
\mathrm{C}\end{array}$ & 0 & $\begin{array}{l}0 \\
\mathrm{C}\end{array}$ & 0 \\
\hline exterior reflectance & 0 & 0 & 0 & 0 & 0 & 0 \\
\hline dimenslons of walls, & A & A & A & A & A & A \\
\hline
\end{tabular}

INDOOR ENVIRONMENT (BY ZONE)

dry bulb temperature

relative humidity

air quality

lighting quality

air movement

interlor vegetation

interior fountains

fireplaces, woodstoves,

kerosene heaters

OCCUPANCY

number of people

bldg. operation hrs/wk

cleaning hours

work schedules

activities

smoking rules

location of occupancy

maintenance protocol

$\begin{array}{lll} & & \\ 0 & 0 & C \\ 0 & 0 & 0 \\ 0 & 0 & 0 \\ \text { A } & \text { A } & \text { A } \\ \text { A } & \text { A } & \text { A } \\ \text { A } & \text { A } & \text { A }\end{array}$

$\begin{array}{llll}\text { C } & \text { C } & \text { C } & \\ \text { C } & \text { C } & \text { C } & \\ 0 & 0 & 0 & 0 \\ 0 & 0 & 0 & 0 \\ 0 & 0 & 0 & 0 \\ A & A & A & A \\ \text { A } & \text { A } & A & A \\ \text { A } & \text { A } & \text { A } & \text { A }\end{array}$

SITE ENVIRONMENT

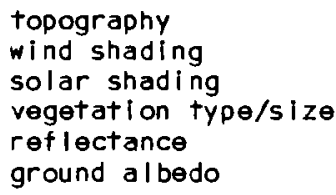

topography

wind shading

solar shading

vegetation type/size

reflectance

ground albedo

$\begin{array}{lll}A & A & A \\ A & A & A \\ R & R & R \\ A & A & A \\ A & A & A \\ A & A & A\end{array}$

E - data available from existing source.

A - data obtained from observation or building audit.

0 - data obtained from a one-time test.

R - data obtained from recurrent tests or measurements.

C - data obtained trom continuous measurements (hourly or sub-hourly). 
key letters used in Table 4.4. A blank in the table indicates that collection of the data type is considered to be either unnecessary, or a low priority for the particular research area. The determination of the type of measurements required was based upon recommendations of the technical advisory committee and discussions with professionals working in the appropriate research areas.

\subsection{PERFORMANCE FACTORS}

Continuous metering and hourly data collection yields an overwhelming quantity of data. Since this data is time consuming to process, many of the users of metered data desire data summaries. Therefore, to ensure widespread use of the data, it is necessary to develop appropriate summary statistics on the building's energy related performance. The selection of statistics for summarizing the data must be carefully made, since the summaries must not only convey the information most frequently desired, but also retain the significance of the hourly end-use resolution. These statistics, or measures, are called "performance factors". A performance factor relates energy consumption to a building's characteristic(s) climatological condition(s), or other normalizing factors. The performance factors do not represent the total package of analyses that can and should be done on each building. They represent a minimum amount of reduction and normalization of the data that should be concurrent with the data collection process. The following discussion of performance factors was developed in cooperation with the Architectural Energy Corporation under contract to PNL.

The performance factors have been divided into five categories: energy consumption and peak demand (4.3.1), energy performance ratios (4.3.2), equipment and component efficiencies (4.3.3), building shell parameters (4.3.4), and indoor thermal comfort measures (4.3.5). The first two categories are primarily derived from the continuous measurements. Equipment efficiencies are most likely to be based upon one-time tests, although they can also be based upon continuous measurements. The fourth category, building shell parameters, is based upon either data collected from the building audit, or one-time tests. The fifth category, indoor comfort, is derived from continuous measurement but 
is not linked to a building characteristic. Each of these five categories is briefly reviewed in the following paragraphs.

\subsubsection{Energy Consumption and Peak Demand}

The most basic energy performance factor is the total building energy consumption, which can be separated by end use into heating, cooling, ventilating, lighting, water heating, and other energy use. End-use energy consumption needs to be aggregated and normalized over time periods larger than one hour. Three recommended time periods are: daily (for selected days of the year), monthly, and yearly. The days selected should include a typical meteorological weekday and weekend day in each season of the year. Typical meteorological days can be based on NOAA data. In addition to summaries by end use, summaries by fuel types are also desired by some researchers.

Peak electric demand is an important element of commercial building energy costs. It is useful to know the peak demand for the total building and each end use for each hour of the day. This indicates the building's absolute hour peak demand, as well as its maximum demand at the time of the electric utility's peak, and the end-use breakdown indicates which energy-using functions drive the peak loads. Suggested performance factors are 1isted in Table 4.5 .

\subsubsection{Energy Performance Ratios}

A simple and widely-used method for comparing building energy performance is the calculation of energy performance ratios. These ratios take the building energy consumption, by end use or total, and normalize according to number of occupants, floor area, climate, etc. This technique eliminates sources of bias and confusion that are inherent in comparing the energy performance of buildings on the basis of a simple energy quantity. The challenge of course, is to establish a simple but consistent basis of comparison. For most commercial buildings, where lighting and internal loads dominate the energy processes, the most consistent basis is probably Btu/person - year. For multifamily residential buildings where occupancy is less dense, the $B t u / \mathrm{ft}^{2}$ - year basis is probably more appropriate. Normalizing by climate (Btu/ft ${ }^{2}$ - DD (degree/day) or Btu/person -DD) is relevant only for heating energy use, and is 
TABLE 4.5. Energy Consumption and Peak Demand Performance Factors Total Building Energy Consumption (Btu/yr), (Btu/mo), (Btu/hr-typical day) ${ }^{(a)}$

End-Use Energy Consumption (Btu/yr), (Btu/mo), (Btu/hr-typical day) (a)

Average hourly end-use energy consumption $(B t u / h r)(a)$

Average day-of-week end use and energy consumption (Btu/day)(a) Heating

Cooling

Ventilation

Lighting

Water Heating

Other

Peak Electric Demand by Time-of-Day (W)

End-Use Electric Demand by Time-of-Day (W)

Hourly End-Use Profiles/Typical Day/Season

(a) Also by fuel type.

not recommended for larger buildings that are dominated by internal loads. Suggested normalized performance ratios are 1 isted in Table 4.6 .

\subsubsection{Equipment and Component Efficiencies}

Because of the importance of HVAC, lighting, and other equipment to commercial building energy use, equipment/component efficiencies are significant performance factors. HVAC equipment efficiency or coefficient of performance (COP) can often be a function of the temperature difference between the indoor and outside ambient environment. Such functions can usually be calculated or measured on a one-time basis and then integrated over the long-term by a simulation program or data acquisition system.

Daylighting and other solar utilization efficiencies should be included in a building performance evaluation program, even if the program does not focus on buildings specifically designed to use solar energy. One reason is that establishing a conventional building data-base will make the results of solar 
TABLE 4.6. Energy Ratio Performance Factors

Total Energy Consumption-Normalized (Btu/person-yr or Btu/ft2-yr)

End-Use Energy Consumption-Normalized

Heating (Btu/person-yr or Btu/ft $\mathrm{f}^{2}-\mathrm{yr}$ or Btu/ft $\mathrm{f}^{2}-\mathrm{DD}$ )

Cooling (Btu/person-yr or Btu/ft $\mathrm{ft}^{2}-\mathrm{yr}$ )

Ventilation (Btu/person-yr or Btu/ $\mathrm{ft}^{2}-\mathrm{yr}$ )

Lighting ( $W / \mathrm{ft}^{2}$ or Btu/person-yr or Btu/ft' $\mathrm{ft}^{2} \mathrm{yr}$ )

Water Heating (Btu/person-yr or Btu/ft $\mathrm{ft}^{2} \mathrm{yr}$ or Btu/gal)

other (Btu/person-yr or Btu/ft' ${ }^{2}-y r$ )

or energy-conserving building monitoring more meaningful. For example, if daylighting and ventilative cooling save $20,000 \mathrm{Btu} / \mathrm{ft}^{2}-\mathrm{yr}$ in a solar building, a data set of this type would allow estimation of the savings that could be accomplished in a more conventional building. Equipment related performance factors are listed in Table 4.7 .

\subsubsection{Building Shell Parameters}

The thermal parameters of the building envelope are themselves important performance factors. These parameters can generally be determined using onetime or short-term tests. Basically, these parameters indicate the thermal response of the building to outdoor air temperature, indoor air temperature, and outdoor-to-indoor air exchanges, and solar or internal heat gains. Building shell parameters are 1 isted in Table 4.8 .

\subsubsection{Indoor Thermal Comfort Measures}

Energy use and building characteristics are not the only criteria for assessing building thermal performance. The HVAC system must deliver an acceptable indoor environment regardless of its energy use. The simplest thermal comfort measure is dry-bulb temperature, expressed in terms of average daily maxima and minima. More sophisticated comfort measures will account for humidity, radiant effects, and air movement. Indoor comfort measures are listed in Table 4.9 . 
TABLE 4.7. Equipment and Component Performance Factors

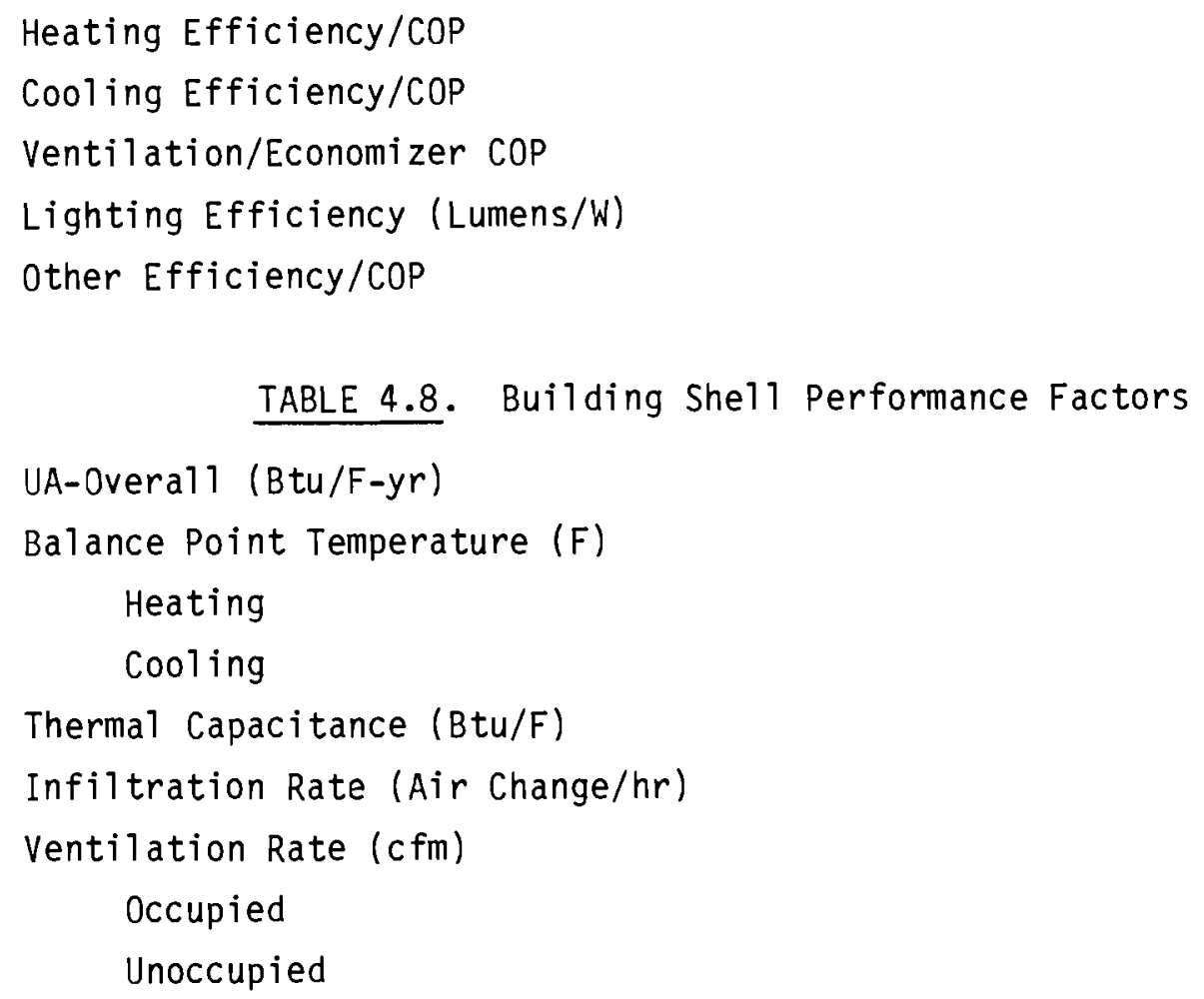

TABLE 4.9. Indoor Comfort Performance Factors

Dry-Bulb Temperatures ( ${ }^{\circ} \mathrm{F}$-Average Daily Extremes)

Wet-Bulb Temperatures ( ${ }^{\circ} \mathrm{F}$-Average Daily Extremes)

\subsubsection{Summary of Performance Factors}

It is recommended that any metered data collection or analysis efforts consider using the preceding factors as measures of building performance. It is believed that the performance factors provide a format for analyzing building energy consumption data that is useful to a wide range of research needs. It also provides a basis for quick comparisons of data from different metering projects. 


\subsection{DOCUMENTATION OF METERED DATA INVENTORY}

Documentation of the data collected in the inventory exists in three sources. The information collected through the survey, phone contacts, and meetings are a11 recorded on the form included in Appendix A. These forms are part of the project records maintained at PNL. The second archived source of information is a microcomputer data base that contains most of the information on the survey forms. This report is the third source of documentation.

\subsection{DESCRIPTION OF DATA BASE}

Section 3 includes a description of the approaches employed to inventory existing sources of metered data. Metered data identified at these multiple sources were summarized in a standardized format and entered into a microcomputer data base. A11 comprehensive end-use metered data from typical commercial buildings are included in the data base. Data consisting of only total energy consumption or selected end-use metered data in commercial buildings are not included in the data base if the project is already included in another published inventory. These projects were not included because they are outside the project scope (whole-building end-use metering of typical commercial buildings) and inclusion would be an unnecessary duplication of effort.

One disadvantage of the data base is that forcing the data collected into the standardized format did not allow all the details of a project to be recorded. Occasionally, it was difficult to characterize a project given the "standardized" descriptors.

Summaries of the information contained in the data base are included in Tables 3.1, 3.2, and 3.3 and in Appendix B. The following documentation is provided to assist researchers in using the data base. In addition, PNL intends to continue to update and possibly expand the data base to include building descriptors and performance factors pertaining to metered data sets. This data base is maintained in the public domain.

The data base was developed on an IBM personal computer using the MICRORIM data base software. MICRORIM is a relational data base management system that is compatible with RIM, a mainframe package; thus the data can be easily 
adopted to use on a mainframe computer. The definitions and structure of the data base, along with the data, are stored on a $51 / 4$ inch diskette using the PC DOS format. The MICRORIM software is necessary to access and add data to the data base. The following description of the structure of the data base is provided to assist data base users who are already familiar with the RIM or MICRORIM software.

The data base consists of coded answers to the questions on the survey shown in Appendix $A$ and information on each of the contacts made. There are four parts to the data base. Each part is referred to as a "relation," a group of related data. Each datum is referred to as an attribute. Thus, a relation is composed of attributes. The four relations are: MAIL, CONTACTS, METER, and SURVEY. The four relations are linked by a common identification number, which is the attribute "ID". Each contact is assigned a unique ID and all documentation associated with each contact share the same ID. The four relations are briefly described below.

The relation MAIL contains the name, title, company name, address and phone number of each person contacted in the data survey. The relation CONTACTS contains information on whether the contact was made by survey, by mail, by our consultant Architectural Energy Corporation (AEC), through journal advertisements, or in a meeting. If the contact was made by survey, then there is a notation on whether the survey was returned. The relation SURVEY contains information used to describe each metering project. This information includes the name of the project, the contact person, the location of the project, and the types of buildings metered. The relation METER describes each metering project by the time resolution of the collected data, the technique used to collect the data, the data availability, and the types of data collected.

\subsection{DATA BASE STRUCTURE}

The structure and the information contained within the data base are shown in Table 5.1. There are three column headings in Table 5.1. The first heading "relation" shows the relations to which the attribute is assigned. The second column is the attribute name, a variable name in the data base. The third column is a description of what the variable represents. 
TABLE 5.1. Data Base Variables

\begin{tabular}{|c|c|c|}
\hline Relation & Attribute & Attribute Description \\
\hline $\begin{array}{l}\text { Meter, Mai1 } \\
\text { Survey, Contact }\end{array}$ & ID & $\begin{array}{l}\text { Number assigned to each contact or metering } \\
\text { project }\end{array}$ \\
\hline Mai1 & Class & $\begin{array}{l}\text { Type of contact (utility, engineering firm, } \\
\text { etc.) }\end{array}$ \\
\hline Mail, Contact & Name & Name of contact \\
\hline Mai1 & Title, Title 1 & Professional title of contact \\
\hline $\begin{array}{l}\text { Mai1, Contact } \\
\text { Survey }\end{array}$ & Comp. Name & Name of Company \\
\hline Mai1 & Address & Street address of contact \\
\hline Mai 1 & City & City \\
\hline Mail & State & State \\
\hline Mail & Zip & Zip Code \\
\hline Mai1, Contact & Phone & Phone number \\
\hline Contact & Con. needed & $\begin{array}{l}\text { Status-whether it is necessary to contact } \\
\text { the individual }\end{array}$ \\
\hline Contact & Q. Mailed & Indicates how contact was made \\
\hline Contact & Q. Received & $\begin{array}{l}\text { Indicates whether questionnaire was } \\
\text { returned }\end{array}$ \\
\hline Survey & Company & Company which did metering \\
\hline Survey, Meter & Prog. Name & Name of metering project \\
\hline Survey & Prog. Con. & Contact person for metering project \\
\hline Survey & Con. Phone & Phone number of contact \\
\hline Survey & B1dg. Typ. & Building type metered \\
\hline Survey & Location & Location of buildings metered \\
\hline Survey & Star. Per. & Date when metering started \\
\hline Survey & End. Per. & Date when metering ended \\
\hline
\end{tabular}


TABLE 5.1. (contd)

\begin{tabular}{|c|c|c|}
\hline Relation & Attribute & Attribute Description \\
\hline Meter & Data Type & Description of metered data collected \\
\hline Meter & Data Avail. & $\begin{array}{l}\text { Whether the data is in the private or } \\
\text { public domain }\end{array}$ \\
\hline Meter & M. Tech. & How the data was collected \\
\hline Meter & Time. Res. & The time resolution of the meter data \\
\hline
\end{tabular}

In order to simplify the entry of data a set of data entry forms were developed. These forms can be called to the computer screen using the "ENTER" command in RBASE. There are four forms, one for each relation. The form names and their correspondence to the relations are listed in Table 5.2. Use of the forms for entering the data is recommended, since code letters and numbers are used for the following attributes: "CLASS", "Q. MAILED", "DATA TYP", "DATA, AVA", "M. TECH", and "TIME. RES". The codes are explained on the data entry form. An example of the data entered for a metering project is provided in Tables 5.3 and 5.4. The example provided is for the metering of an office building by Pacific Northwest Laboratory. Tables 5.3 and 5.4 shows the data entry forms for the relations SURVEY and METER, respectively. These forms were completed for each project in the data base.

TABLE 5.2. Data Entry Forms

\begin{tabular}{|c|c|}
\hline Form Name & Relation \\
\hline Contact & Contacts \\
\hline Mailist & Mail \\
\hline Quest 1 & Survey \\
\hline Quest 2 & Meter \\
\hline
\end{tabular}


TABLE 5.3. Survey Data Entry Form

THIS FORM IS THE FIRST PART OF THE DATA ENTRY

FROM THE QUESTIONNAIRE

ID NUMBER:118

COMPANY NAME:PACIFIC NORTHWEST LABORATORY (NOT NECESSARY IF THERE IS AN ID)

NAME OF PROJECT:SIGMA IV METERING PROJECT

CONTACT PERSON: JAMES HEIDELL

CONTACT PERSON PHONE NUMBER:(509) 376-4738

BUILDING TYPE: SMALL OFFICE

LOCATION: RICHLAND, WA

DATE METERING STARTED (MM/DD/YR):04/01/83

DATE METERING ENDED (MM/DD/YR):

NOTE: THE ID NUMBER IS IMPORTANT TO TRACK DATA

CHECK MAILING LIST TO SEE WHETHER AN ID

HAS BEEN ASSIGNED

TABLE 5.4. Meter Data Entry Form

THIS FORM IS USED TO CHARACTERIZE METERED DATA

PROJECT ID:118 PROJECT NAME:SIGMA IV METERING STUDY

TYPE OF DATA:29 CODE CODE DATA AVAILABILITY:1 CODE

$\begin{array}{lllll}\text { TOTAL CONSUMPTION } 1 & \text { END-USE CONSUM. } 21 & \begin{array}{l}\text { PUBLIC DOMAIN } \\ \text { PROPRIETARY }\end{array} & 1 \\ 2\end{array}$

TOTAL \&

BLDG CHAR

BLGG OPER

MICRO CLIM

EQUIP PERFORM

ALL ABOVE

END-USE \&

BLDG CHAR

BLDG. OPER

22

BLDG. OPER 23

MICRO CLIMATE 24

EQUIP. PERFORM 25

ALL ABOVE 26

CHAR, PERFORM

CHAR, PERFORM 27

CLIM, PERFORM 28

CHAR, CLIM

CHAR, OPER

CLIM, PERFORM

CHAR, CLIM

CHAR, OPER

30

OPER, PERFORM

10

CHAR, CLIM, PERFOR 12

CHAR, OPER, PERFOR 13

CHAR, CLIM, PER 32

CHAR, OPER, PER 33

METERING TECHNIQUE:4 CODE

MANUAL RECORDS 1

STRIP CHART RECORDER 2

UTILITY DEMAND METER 3

MICROPROCESSOR

4

RESOLUTION OF DATA:2 CODE

SUB-HOURLY

HOURLY

DAILY

MONTHLY 


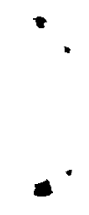

. 


\subsection{SUMMARY OF END-USE METERING PROJECTS MEETING PROGRAM CRITERIA}

Table 2.1 lists 39 data sets which at a minimum contain useful end-use metered data. This section briefly summarizes the subset of those metering projects where metering took place for a one year period. A one year period is necessary in order to examine an important component of building energy analysis: the impact of climate on building energy use. This constraint eliminated an additional fifteen buildings from the list. The summaries provide a brief building description as well as end-use energy consumption data.

\subsection{PROJECT ON RESTAURANT ENERGY PERFORMANCE}

The Project On Restaurant Energy Performance (PREP) involved metering of seven restaurants in the Northeast United States by Pacific Northwest Laboratory in conjunction with the National Restaurant Association and Pennsylvania State University. The seven restaurant types metered as well as a brief description of the restaurant characteristics are shown below in Table 6.1.

TABLE 6.1. Restaurants Metered

\begin{tabular}{|c|c|c|c|}
\hline Restaurant Type & Square Ft & $\%$ Kitchen & Space Heat Fuel \\
\hline fast food limited menu & 3,090 & 50 & electrical \\
\hline fast food expanded menu & 2,750 & 60 & gas \\
\hline cafeteria & 10,152 & 25 & electrical \\
\hline pizza & 2,275 & 35 & electrical \\
\hline coffee shop & 4,210 & 20 & heat-pump \\
\hline dinner house limited menu & 6775 & 20 & electrical \\
\hline dinner house expanded menu & 9485 & 30 & gas \\
\hline
\end{tabular}

The seven facilities were metered between the period of July, 1983 and June, 1984. End-use energy consumption as well as micro climate data was collected and archived on a 15 minute aggregation period. Detailed documentation including a description of the metering equipment, the facilities metered, and 
the data collected are available and the references are included in the bibliography. In this section, the facilities are briefly described and summaries of the data are provided. The seven restaurants were selected to represent a range of facilities. The restaurant types are: fast food limited menu, full service restaurant, coffee shop, cafeteria, pizza house, fast food extended menu, and a full service limited menu facility.

The data are available in a number of formats. The field data are available in an ASCII format which has channel by channel data at fifteen minute intervals. In addition, ASCII files which have the daily totals for each channel are also available. The documentation of the project includes several summary reports of the data.

\section{1 .1 Fast Food}

The fast food limited menu facility located in Philadelphia is a one story 3100 square foot building built on a slab. The wall layers consist of brick, plywood, $31 / 2$ inch batt insulation, and GYP board. The restaurant is open 362 days a year from 7:00 a.m. to 11:00 p.m. Sunday - Thursday and 7:00 a.m. to midnight on Fridays and Saturdays. There is a limited breakfast menu and for the rest of the day the menu consists primarily of hamburgers, specialty sandwiches, french fries, soft drinks, and milk shakes.

The restaurant uses natural gas for broiling and frying foods. Food broiling is done with a chain broiler which operates continuously during restaurant operation. Natural gas is also used for hot water heating. Hot water is primarily used for cleaning the restaurant since there is no dish washing. The restaurant HVAC equipment includes five rooftop heating/cooling units and broiler and fryer hood fans. The end-use energy summary for this building is shown in Table 6.2 .

\subsubsection{Full Service Restaurant}

The full service restaurant is located in Springfield, Virginia. The 9500 square foot facility includes three dining rooms and a large bar. The restaurant is open 363 days a year with a weekday schedule of $11: 30 \mathrm{a} . \mathrm{m}$. to 2:30 p.m. for lunch and 5:30 p.m. to 10:00 p.m. for dinner. On weekends the schedule is 5:30 p.m. to $11: 00 \mathrm{p} . \mathrm{m}$. The building equipment includes four 
TABLE 6.2. Fast Food (1 imited menu - $3100 \mathrm{sq} f \mathrm{ft}$ )

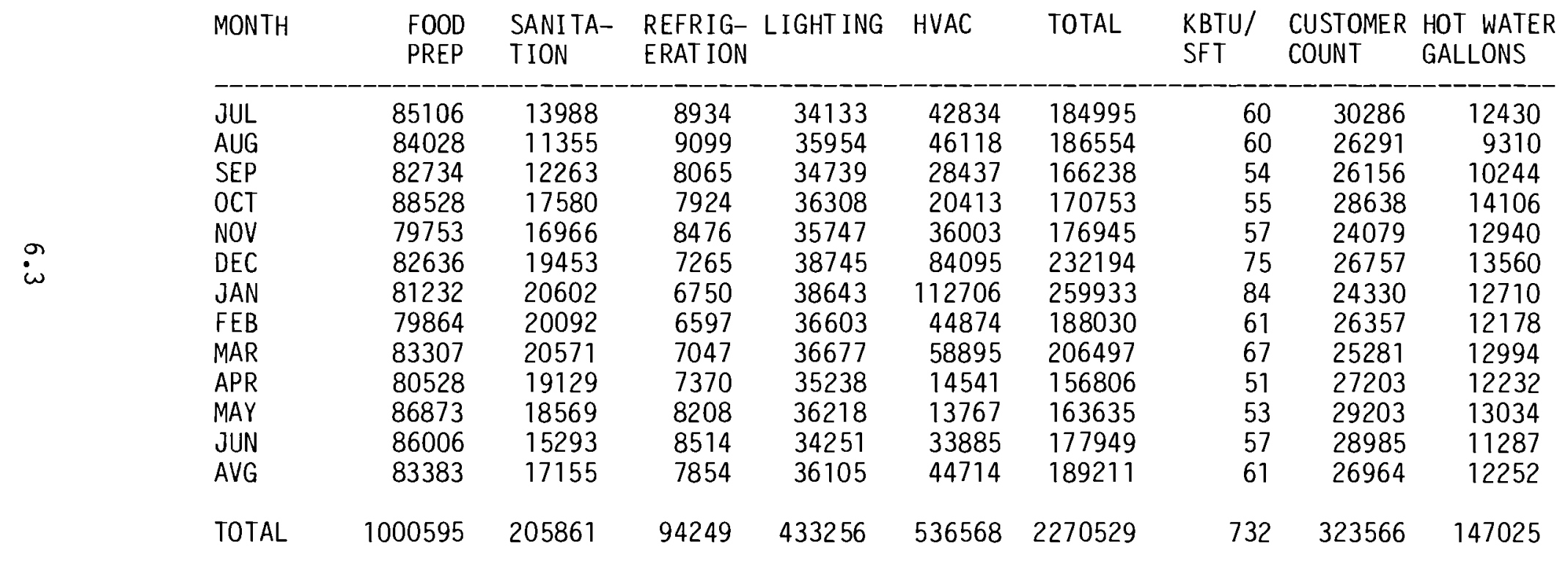


refrigerators, one walk-in freezer, one ice machine, gas hot water and dish washing equipment, and primarily gas food preparation equipment except for an electric beef oven, steamer, and coffee maker. The HVAC equipment consists of five gas heating units and five electric air conditioners. The monthly end-use energy profiles for this restaurant are shown below in Table 6.3.

\subsubsection{Coffee Shop}

The coffee shop is located in Lancaster, Pennsylvania. The one story 4210 square foot facility is open 363 days a year with an extended summer hour schedule. The winter schedule is 7:00 a.m. to 11:00 p.m. on Sundays through Thursdays and 7:00 a.m. to midnight on Fridays and Saturdays. In the summer the facility closes one hour later. The HVAC equipment includes two electric heat pumps with back-up resistance heating. In addition, there are two exhaust fans: one for the grill and one for the fryer.

The restaurant offers a fixed menu including breakfast items such as eggs, hashbrowns, and juices and a lunch/dinner menu consisting of sandwiches, soups, salads, and a few dinner platters. Most of the food delivered to the restaurant is pre-packaged and frozen. The specialty for the restaurant is ice cream. Little energy is used for food preparation. Monthly end-use energy consumption for this facility is shown below in Table 6.4.

\subsubsection{Cafeteria}

The cafeteria restaurant is a 10,150 square foot building located in Williamsburg, Virginia. The cafeteria is open for breakfast from 7:00 a.m. to 10:00 a.m. March 15 through November 4. Lunch and dinner hours for that time period are 11:30 a.m. to 9:00 p.m. During the rest of the year only lunch and dinner are served and the restaurant is open from 11:30 a.m. to 8:00 p.m. The menu includes desserts from an on-site bakery, salads, entrees, side dishes, breads, and non-alcoholic beverages. This facility uses a large amount of energy for food preparation due to the bakery and the need to keep the food at proper temperatures in the serving line.

The cafeteria uses only electricity. The energy consuming equipment for food preparation includes the following: two grills, three fryers, two bake 
TABLE 6.3. Dinner House (full menu - $9500 \mathrm{sq} f t$ )

in

\begin{tabular}{lrrrrrrr}
$\begin{array}{l}\text { FOOD } \\
\text { PREP }\end{array}$ & $\begin{array}{l}\text { SANITA- } \\
\text { TION }\end{array}$ & $\begin{array}{l}\text { REFRIG- LIGHTING } \\
\text { ERATION }\end{array}$ & HVAC & TOTAL & $\begin{array}{l}\text { KBTU/ } \\
\text { SFT }\end{array}$ & $\begin{array}{l}\text { CUSTOMER } \\
\text { COUNT }\end{array}$ \\
\hline 30193 & 58304 & 33498 & 49201 & 142570 & 413766 & 44 & 27146 \\
137023 & 65905 & 34886 & 48889 & 146111 & 432814 & 46 & 28281 \\
33994 & 76092 & 31330 & 47781 & 106318 & 395515 & 42 & 26275 \\
140664 & 102445 & 28687 & 50088 & 73092 & 394976 & 42 & 29128 \\
145153 & 118655 & 26695 & 47983 & 62360 & 400846 & 42 & 29645 \\
149156 & 137711 & 27160 & 48816 & 147872 & 510715 & 54 & 29729 \\
50621 & 141077 & 27945 & 50031 & 167086 & 536760 & 57 & 27002 \\
143492 & 123019 & 25960 & 46786 & 101562 & 440819 & 46 & 11488 \\
151985 & 136949 & 27499 & 51738 & 107532 & 475703 & 50 & 29815 \\
138973 & 119398 & 28653 & 48604 & 53185 & 388813 & 41 & 26415 \\
142324 & 93550 & 30254 & 49527 & 86076 & 401731 & 42 & 28615 \\
131966 & 81145 & 30828 & 48010 & 132772 & 424721 & 45 & 28781 \\
13036 & 78391 & 23560 & 36716 & 88436 & 347812 & 37 & 21488 \\
& & & & & & & \\
1695544 & 1254250 & 353395 & 587454 & 1326536 & 5217179 & 551 & 322320
\end{tabular}


TABLE 6.4. Coffee Shop (4210 sq ft)

\begin{tabular}{|c|c|c|c|c|c|c|c|c|c|}
\hline MONTH & $\begin{array}{l}\text { FOOD } \\
\text { PREP }\end{array}$ & $\begin{array}{l}\text { SANI TA- } \\
\text { TION }\end{array}$ & $\begin{array}{l}\text { REFRIG- } \\
\text { ERATION }\end{array}$ & LIGHT ING & HVAC & TOTAL & $\begin{array}{l}\text { KBTU/ } \\
\text { SFT }\end{array}$ & $\begin{array}{l}\text { CUSTOMER } \\
\text { COUNT }\end{array}$ & $\begin{array}{l}\text { HOT WATER } \\
\text { GALLONS }\end{array}$ \\
\hline JUL & 62580 & 24370 & 6611 & 18200 & 52838 & 164599 & 39 & 40487 & 31430 \\
\hline$A \cup G$ & 64439 & 23733 & 6718 & 18777 & 50756 & 164423 & 39 & 39825 & 30790 \\
\hline SEP & 50839 & 24907 & 5918 & 19237 & 26109 & 127010 & 30 & 26944 & 26612 \\
\hline OCT & 41398 & 28317 & 4791 & 24547 & 11127 & 110180 & 26 & 24187 & 26752 \\
\hline NOV & 37143 & 26074 & 3899 & 24217 & 21915 & 113248 & 27 & 19489 & 23990 \\
\hline DEC & 33823 & 26657 & 3294 & 24088 & 59877 & 147739 & 35 & 17211 & 20565 \\
\hline JAN & 29751 & 27254 & 3496 & 24489 & 83024 & 168014 & 40 & 14312 & 22194 \\
\hline FEB & 29269 & 29405 & 3397 & 23909 & 44382 & 130362 & 31 & 16998 & 29688 \\
\hline MAR & 31645 & 37937 & 3845 & 25366 & 51311 & 150104 & 36 & 19813 & 37936 \\
\hline APR & 32476 & 37909 & 5276 & 23939 & 15173 & 114773 & 27 & 24316 & 47376 \\
\hline MAY & 33642 & 38394 & 5356 & 23075 & 16053 & 116520 & 28 & 24463 & 52644 \\
\hline JUN & 34048 & 36484 & 5889 & 23089 & 38417 & 137927 & 33 & 27883 & 56396 \\
\hline$A V G$ & 40088 & 30120 & 4874 & 22744 & 39249 & 137075 & 33 & 24661 & 33864 \\
\hline TOTAL & 481053 & 361441 & 58490 & 272933 & 470982 & 1644899 & 391 & 295928 & 406373 \\
\hline
\end{tabular}


ovens, four ranges, and a steam boiler. The steam boiler is also used for sanitation along with two hot water heaters, a dryer, a washer, and a dishwasher. Refrigeration equipment includes the following: two ice machines, a walk-in freezer, three walk-in coolers, and three reach-in refrigerators. HVAC energy is supplied by three roof-top units with back-up duct heaters. The monthly end-use energy profiles for this building are shown below in Table 6.5 . 6.1.5 Pizza House

The one story 2210 square foot restaurant is located in Bensalem township north of Philadelphia. The restaurant is open 363 days a year from 12:00 p.m. to 11:00 p.m. on Sundays, 11:00 a.m. to 11:00 p.m. Mondays through Thursdays, and 11:00 a.m. to 1:00 a.m. on Fridays and Saturdays. During winter hours (Labor day through May) the restaurant closes at 12:00 a.m. on Fridays and Saturdays. The menu consists primarily of pizza with a limited selection of pasta dishes, sandwiches, and a salad bar. The dough is made from scratch and the pizza oven is the primary energy consumer. The oven, which consumes approximately $28 \%$ of the entire energy consumption, is operated continuously from opening to closing.

The only fuel source is electricity. The restaurant has a single HVAC unit for heating and cooling. Food preparation equipment includes the pizza oven and a food warmer. Sanitation equipment includes a water heater, a hot water heater booster, and a dishwasher. Energy use of this facility is shown below in Table 6.6 .

\subsubsection{Fast Food Extended Menu}

This 3100 square foot facility is located in Willingboro, New Jersey. This restaurant serves lunch and dinner 363 days a year. The business hours are 10:00 a.m. to midnight Sundays through Thursdays and 10:00 a.m. to 1:00 a.m. on Fridays and Saturdays. During winter hours (Labor Day through May) the restaurant closes one hour earlier. The menu includes hamburger items, roast beef sandwiches, fried chicken, french fries, soft drinks, milk shakes, and a limited selection of desserts. Roast beef and chicken are delivered daily and the balance of the food is frozen and cooked at the restaurant. 
TABLE 6.5. Cafeteria $(10,150 \mathrm{sq} f t)$

\begin{tabular}{|c|c|c|c|c|c|c|c|c|c|}
\hline & MONTH & $\begin{array}{l}\text { FOOD } \\
\text { PREP }\end{array}$ & $\begin{array}{l}\text { SANITA- } \\
\text { TION }\end{array}$ & $\begin{array}{l}\text { REFRIG- } \\
\text { ERAT ION }\end{array}$ & LIGHT ING & HVAC & TOTAL & $\begin{array}{l}\text { KBTU/ } \\
\text { SFT }\end{array}$ & $\begin{array}{l}\text { CUSTOMER } \\
\text { COUNT }\end{array}$ \\
\hline & $\begin{array}{l}\text { JUL } \\
\text { AUG } \\
\text { SEP } \\
\text { OCT } \\
\text { NOV } \\
\text { DEC } \\
\text { JAN } \\
\text { FEB } \\
\text { MAR } \\
\text { APR } \\
\text { MAY } \\
\text { JUN } \\
\text { AVG }\end{array}$ & $\begin{array}{l}229349 \\
232717 \\
224305 \\
228282 \\
182852 \\
170539 \\
146361 \\
152299 \\
201565 \\
241479 \\
238077 \\
215999 \\
205319\end{array}$ & $\begin{array}{l}154993 \\
150978 \\
158319 \\
160538 \\
137210 \\
124418 \\
113950 \\
118161 \\
165824 \\
195671 \\
176570 \\
146435 \\
150256\end{array}$ & $\begin{array}{l}20112 \\
23262 \\
18915 \\
18460 \\
16087 \\
12992 \\
12722 \\
13691 \\
14285 \\
16591 \\
17643 \\
19049 \\
16984\end{array}$ & $\begin{array}{l}39083 \\
39134 \\
38067 \\
39720 \\
35646 \\
34695 \\
31953 \\
30727 \\
34152 \\
39143 \\
42869 \\
39931 \\
37093\end{array}$ & $\begin{array}{r}124749 \\
123337 \\
88662 \\
71216 \\
79482 \\
149459 \\
192431 \\
101945 \\
107252 \\
69148 \\
75315 \\
120276 \\
108606\end{array}$ & $\begin{array}{l}568286 \\
569428 \\
528268 \\
518216 \\
451277 \\
492103 \\
497417 \\
416823 \\
523078 \\
562032 \\
550474 \\
541690 \\
518258\end{array}$ & $\begin{array}{l}56 \\
56 \\
52 \\
51 \\
44 \\
48 \\
49 \\
41 \\
52 \\
55 \\
54 \\
53 \\
51\end{array}$ & $\begin{array}{l}57180 \\
54904 \\
45238 \\
55641 \\
34919 \\
26538 \\
17047 \\
20358 \\
33503 \\
51836 \\
57362 \\
51552 \\
42173\end{array}$ \\
\hline & TOTAL & 2463824 & 1803067 & 203809 & 445120 & 1303272 & 6219092 & 613 & 506078 \\
\hline
\end{tabular}


TABLE 6.6. Pizza House (2210 sq ft)

\begin{tabular}{llrrrrrr} 
FOOD & SANITA- & $\begin{array}{l}\text { REFRIG- LIGHTING } \\
\text { PREP }\end{array}$ & TION & HVAC & TOTAL & $\begin{array}{l}\text { KBTU/ } \\
\text { ERATION }\end{array}$ & $\begin{array}{l}\text { CUSTOMER } \\
\text { COUNT }\end{array}$ \\
\hline 34876 & 17837 & 10278 & 12160 & 42885 & 118036 & 52 & 18639 \\
33755 & 17023 & 10149 & 12019 & 40737 & 113683 & 50 & 18596 \\
31379 & 16110 & 9191 & 11602 & 32445 & 100727 & 44 & 19353 \\
31741 & 16438 & 8462 & 11877 & 19907 & 88425 & 39 & 17650 \\
27614 & 15648 & 5175 & 11064 & 8388 & 67889 & 30 & 15878 \\
29067 & 17510 & 5035 & 12327 & 30532 & 94471 & 42 & 14099 \\
27866 & 21622 & 9382 & 12892 & 47989 & 119751 & 53 & 12805 \\
26996 & 14971 & 9501 & 12038 & 19693 & 83199 & 37 & 12890 \\
30618 & 18529 & 8952 & 12935 & 32301 & 103335 & 45 & 15257 \\
29311 & 25667 & 9546 & 12933 & 12007 & 89464 & 39 & 14549 \\
30312 & 17418 & 10451 & 13709 & 20403 & 92293 & 41 & 14610 \\
28177 & 14620 & 10320 & 12986 & 35105 & 101208 & 44 & 12519 \\
30143 & 17783 & 8870 & 12379 & 28533 & 97707 & 43 & 15570 \\
& & & & & & & \\
361712 & 213393 & 106442 & 148542 & 342392 & 1172481 & 515 & 186845
\end{tabular}


The restaurant uses both gas and electricity. HVAC energy is supplied by two roof-top units. One of the units serves the dining area while the other serves the kitchen. The heating is with gas and the cooling is with electricity. Additional HVAC equipment includes four fans: three exhaust fans and one make-up air fan. Sanitation equipment consists of a gas hot water heater and there is no dishwasher. Food preparation equipment includes gas fryers, grill, and ovens. Electric food preparation equipment includes a slow cook oven, coffee maker, shake machine, and and ice cream machine. Monthly end-use energy consumption is shown in Table 6.7 .

\subsubsection{Full Service Limited Menu}

This 6770 square foot facility is located in Alexandria, VA and includes several small dining rooms and a bar. The building is constructed on a six inch concrete slab and the walls are constructed of 4 " brick, 8 " concrete block, and cement plaster. The restaurant serves lunch and dinner and serves lunch from 11:30 a.m.-2:00 p.m. on weekdays. Dinner hours are 5:00 p.m. to 10:00 p.m. Monday - Thursday, 5:00 p.m. to 11:00 p.m. on Fridays and Saturdays, and noon to midnight on Sundays. The lunch menu includes sandwiches and entrees. Entrees for dinner and lunch are typically red meats although fish and chicken are also available.

The restaurant uses only electricity and kitchen equipment is left on for the entire day. Food preparation equipment includes a convention oven, three broilers, and four ovens. The restaurant has three hot water heaters, a booster heater for the dishwasher, and a dishwasher. HVAC equipment includes three roof-top heating and cooling units, two make-up air fans, and six exhaust fans. The monthly end-use energy profile is shown Table 6.8 .

\subsection{JOLLY TIGER RESTAURANT}

The Jolly Tiger restaurant is a 24 hour family-style restaurant located in Colonie, New York. The building was metered by the Atmospheric Sciences Research Center, State University of New York and W.S. Fleming \& Associates, Inc. The project was designed to test energy reclamation systems for restaurants. The reclamation system consisted of heat storage tanks with waste heat recovery from the air conditioning, refrigeration, and kitchen exhaust systems. 
TABLE 6.7. Fast Food (1imited menu - $2750 \mathrm{sq} \mathrm{ft}$ )

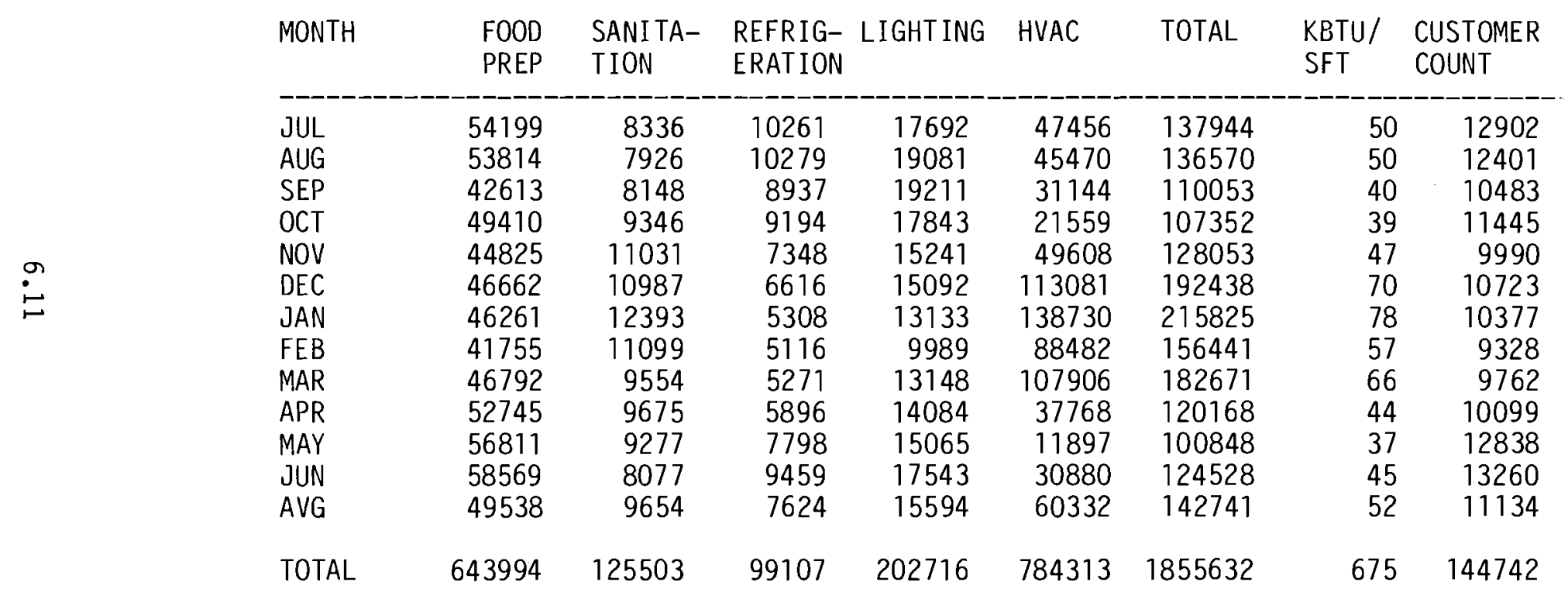


IABLE 6.8. Dinner House (1 imited menu - $6770 \mathrm{sq} \mathrm{ft}$ )

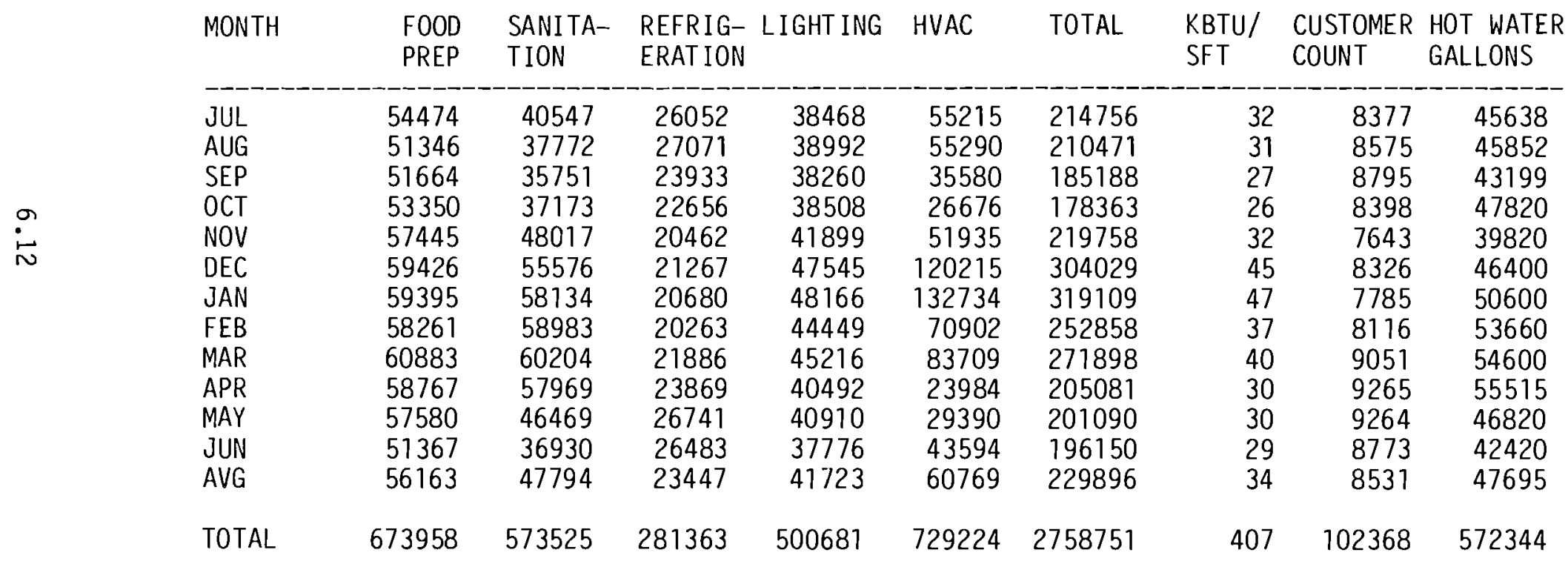


The recovered energy was used for winter operation of the heat pumps and preheating of ventilation air and in the sanitation systems.

The restaurant is 4500 square feet and includes a coffee shop and dining rooms. In addition, an additional 950 square foot building contained the data acquisition system, the heat storage tanks, and a visitor center. The building used liquid natural gas for cooking, space heating, and hot water heating. The end-use energy consumption is shown below in Table 6.9. The building contained three hybird heat pumps, shown in the column "AC", which are air-air and airwater. In addition, there were two a water heat pumps, shown in the column labeled "HP". These heat pumps were coupled with the exhaust heat recovery system.

Table 6.10 illustrates the magnitude of the heat recovery system for this facility. Net recovered energy was approximately $8 \%$ of the purchased energy for the building on an annual basis.

\subsection{PARK PLAZA BUILDING}

The Park Plaza Building was metered by Tishman Research for the U.S. Department of Energy from August 1981 through July, 1983. Construction of the 920,000 square foot building was completed in 1979. The complex consists of a twenty six floor tower with approximately 28,000 square feet per floor, a 38,000 square foot three story building, and 82,000 square feet of underground conditioned space which includes a large computer installation. The building is owned and occupied by Public Service Electric \& Gas Company on New Jersey. Documentation of this project is provided in five volumes which are listed at the end of this report under references.

Due to the complexity of this building, a brief building description only provides an outline of the building. Windows occupy approximately $50 \%$ of the building's shell. The HVAC system includes two 1250 ton centrifugal chillers and two 210 ton screw-type chillers. The heating equipment includes two electric hot water boilers. Additional components of the HVAC system includes heat pumps and heat recovery systems. The building occupancy is approximately 3400 people. Data was collected from over 350 metering points and the metering was integrated with an automated building control system. Sensors included the 


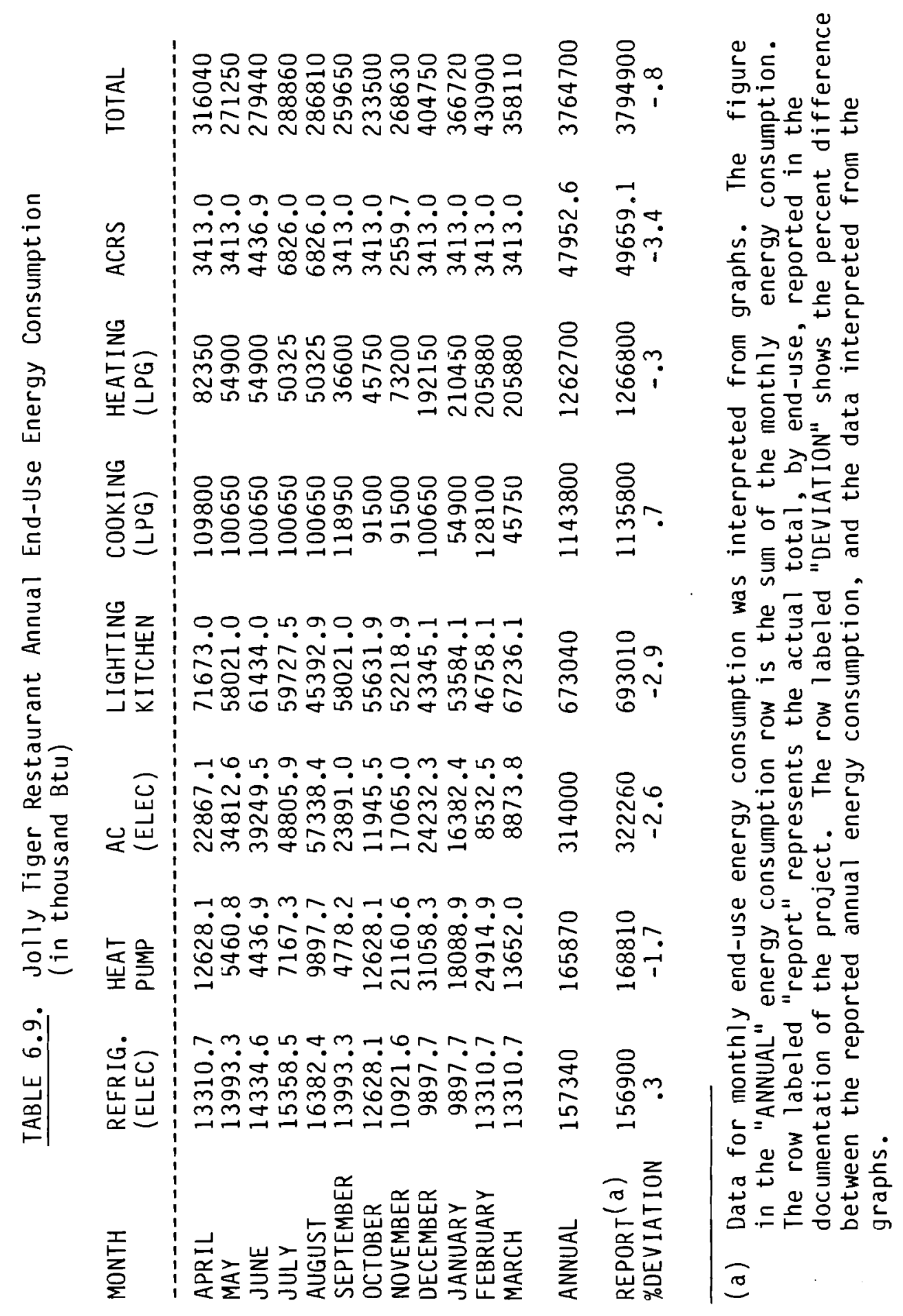


TABLE 6.10. Heat Recovery for the Jolly Tiger Restaurant SYSTEM GROSS ENERGY (KBTU)

NET ENERGY (KBTU)

refrigeration

exhaust air recovery

dishwasher heat exchanger

$A C$ units
121,731

305,989

43,334

12,467

483,521
105,919

137,175

43,334

12,467

total

298,895

following: water flow meters, pressure sensors, air flow monitors, air and water temperature sensors, dewpoint sensors, watthour meters, ammeters, status indicators, and meteorological sensors. A summary of the monthly end-use energy consumption is shown in Table 6.11. The data are shown for the period of August, 1982 through July, 1983. The reclaimed energy from the domestic hot water system and the heating system is shown in Table 6.12 .

\subsection{SIGMA IV}

The sigma IV building is a 20,000 square foot office building located in Richland, WA. This building has been metered since October, 1983 by Pacific Northwest Laboratory under contract to the Department of Energy. The building was built in 1979 and is constructed on a 6 inch concrete slab. The walls are made of wall block, six inch insulation, and GYP board. There is an equal amount of glazing on all four sides of the building. The roof is made up of roof deck and 3 inches of batt insulation and 2 inches of rigid insulation. The HVAC system is made up of ten air-to-air electric heat pumps. The heat pumps range from $31 / 2$ tons to $71 / 2$ tons.

The average peak occupancy is approximately 115 people. The principal period of occupancy is from 7:00 a.m. to $6: 00 \mathrm{p} . \mathrm{m}$. on weekdays. There is limited occupancy after 6:00 p.m. and on weekends. The large amount of electricity consumption is in part due to the computer equipment. On average there is approximately one computer terminal or micro computer for each occupant along with peripherals such as modems and printers. In addition, there is one mini-computer. There is no nighttime temperature setback or off-hour shutdown of HVAC equipment. The end-use energy profile is shown below in Table 6.13. 
TABLE 6.11. Park Plaza Research Building - in MBtu

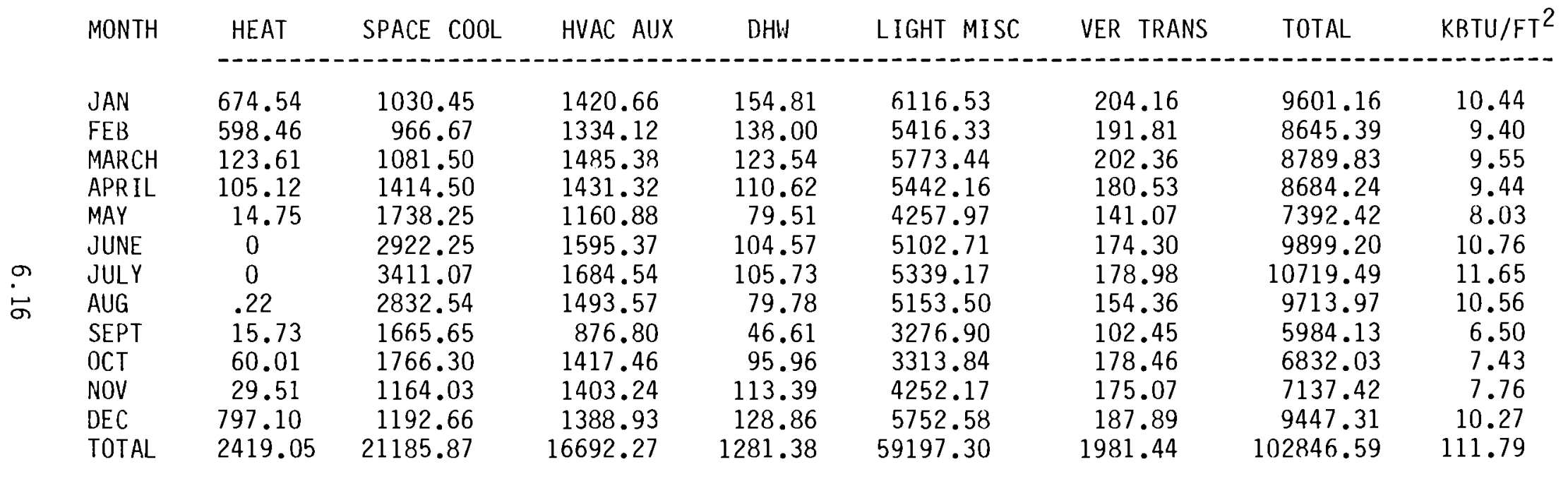


TABLE 6.12. Reclaimed Energy from Park Plaza Building (in MBtu)

\begin{tabular}{lcrr} 
MONTH & HEAT SYSTEM & DHW SYSTEM & \multicolumn{1}{c}{ TOTAL } \\
\hline JAN & 2045.21 & 394.97 & 2440.18 \\
FEB & 1604.37 & 361.09 & 1965.46 \\
MAR & 1370.21 & 344.35 & 1714.56 \\
APR & 809.01 & 314.25 & 1123.26 \\
MAY & 199.23 & 429.63 & 628.86 \\
JUN & 0 & 466.72 & 466.72 \\
JUL & 0 & 504.04 & 504.04 \\
AUG & .01 & 210.22 & 210.23 \\
SEP & .44 & 99.07 & 99.51 \\
OCT & 87.01 & 117.59 & 204.60 \\
NOV & 796.57 & 228.75 & 1025.32 \\
DEC & 1260.67 & 403.22 & 1663.89
\end{tabular}

\subsection{HOTELS AND MOTELS}

Six hotels and motels were metered in 1980 - 1981 by the Department of Energy and the American Hotel and Motel Association. Due to instrumentation and a limited metering plan, data are available for a limited number of enduses and for only part of the heating and cooling season. In addition, end-use energy consumption was often collected for only parts of the facilities. The project is documented in a seven volume series which includes a summary document and one volume for each of the facilities metered. Although these data sets are not complete, short descriptions of the facilities and data summaries are provided in this section.

\subsubsection{Description of Facilities}

Radisson Atlanta Hotel

The Radisson hotel is located in Atlanta, Georgia. The facility includes $163,000 \mathrm{sq} f t$ of guest rooms and corridors along with $45,000 \mathrm{sq} f t$ of public space which includes a dining room, kitchen, and meeting rooms. The building is constructed of cement block walls and reinforced concrete ceilings. The guest rooms are conditioned with through-the-wall electric resistance heating and air conditioning units. The public areas are served by 26 roof-top gas heating and air conditioning systems. Natural gas is used for hot water heating, cooking equipment, and laundry dryers. 
TABLE 6.13. Sigma IV End-Use Energy Consumption in $\mathrm{kWh}$

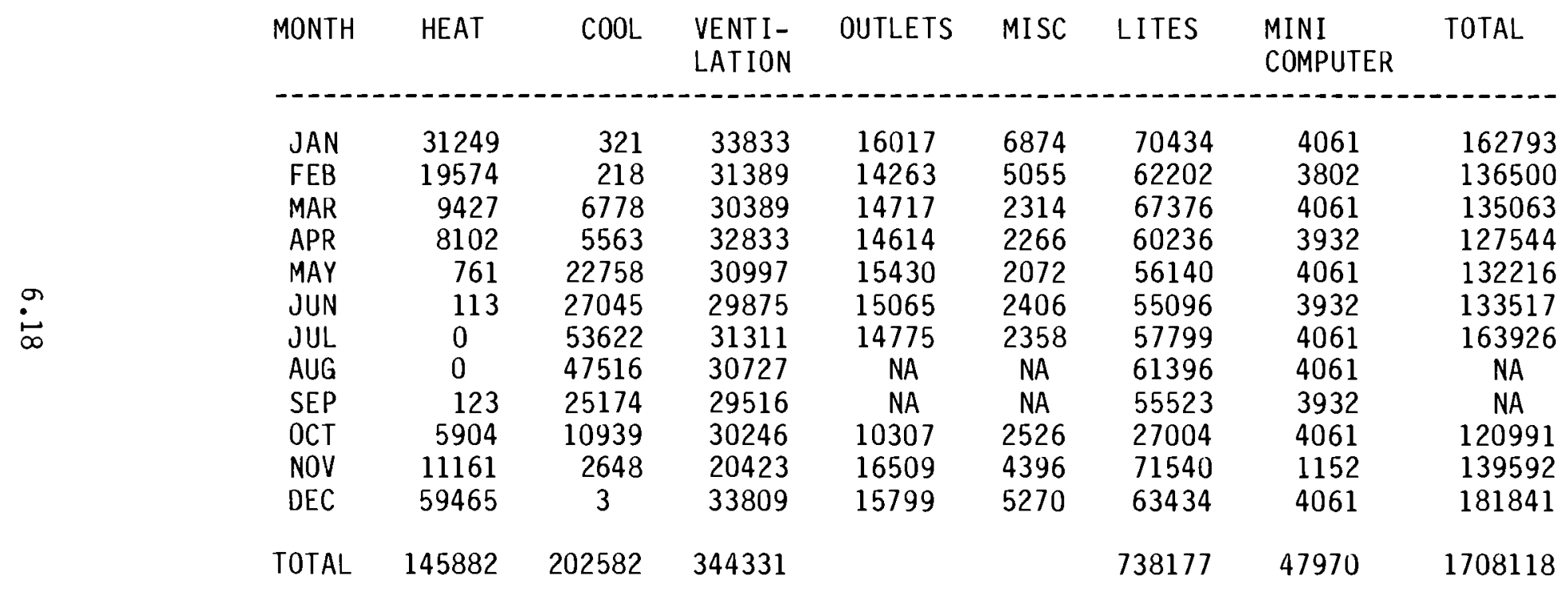

(a) $N A=$ Not Available 
La Quinta Royale

This high rise hotel is located in Corpus Christi, Texas. The hotel contains 200 guest rooms, a restaurant and kitchen, a separate coffee shop and kitchen, a laundry, meeting/banquet rooms, and a swimming pool. The hotel was opened in 1972. The guest rooms are heated and cooled with through-the-wall electric heat pumps. Parts of the public areas are heated and cooled by selfcontained heating and cooling units using natural gas for heating. Other public areas use electric roof top electric heating and cooling units.

Kahler Motel

The Kahler Motel is located in Rochester, Minnesota. The motel includes 126 guest rooms, a restaurant, a kitchen, meeting rooms, a small laundry, and an indoor swimming pool. The HVAC system includes a central two-pipe natural gas heating system. Cooling is via a central plant chiller system with guest room fan coil units. Domestic hot water is provided by gas fired water heaters. Natural gas is also used for kitchen cooling, pool heating, and the dryers in the laundry room.

\section{La Quinta-Airport East}

This motel is located in San Antonio, Texas and consists of 200 guest rooms, a restaurant and kitchen, two meeting rooms, a lounge, laundry, and an outdoor unheated swimming pool. The original facility, containing 128 guest rooms, is heated and cooled by a 4-pipe system and two 60 ton chillers. The newer 72 guest rooms are conditioned with through-the-wall electric units. Domestic hot water is provided by gas fueled boilers. Natural gas is also used by the laundry dryers.

Radisson Scottsdale

This facility is both a resort and racquet club located in Scottsdale, Arizona. The hotel includes 209 guest rooms, laundry facility, small meeting rooms, and restaurant. The HVAC system consists of a four 150 ton reciprocating chillers which serves fan coil units in each of the guest rooms and public areas. The chillers are manually turned off during the winter. Each of the 
fan coil units also contains electric resistance heating. Domestic hot water is provided by a central electric boiler with a booster unit for the kitchen and a separate heater for the laundry.

Woodstock Inn

The Woodstock Inn is a rural resort located in Woodstock, Vermont. The four story resort is built with wood frame construction with a brick exterior. The resort, built in 1969, has 121 guest rooms, dining room, kitchen, and a lobby. The HVAC system consists of a four pipe heating/cooling system. Cooling is provided by electric chillers and space and hot water heating by a central \#4 fuel oil boiler. The facility also has a solar system and heat pumps using exhaust air from the building to preheat the domestic hot water. \#2 Fuel oil is used for some of the kitchen appliances and summer domestic hot water heating. Propane is used for cooking.

\subsubsection{Energy Consumption Profiles}

A combination of the characteristics of the metering plans along with the problems with data collection makes it difficult to provide end-use energy consumption profiles which are similar to the other ones provided in this section of the report. An attempt has been made to reduce the data to a format which is uniform for all the facilities and also provided end-use consumption data. Extensive reporting on the data collected is provided in the documentation of this project. Since not all the projects metered the entire hotel/ motel facility, or even all the guest rooms in the facility, the energy consumption has been normalized by the number of rooms. Heating energy was collected during the winter months and cooling energy during the summer months while domestic hot water as well as lighting and wall outlets was collected in both the summer and winter. The latter two categories have been reported as energy use per room based on a weighted average of the number of observations in the summer and in the winter.

Table 6.14 shows end-use energy consumption for the guest rooms where the energy consumption is normalized by the number of available rooms. The number of available rooms is based on the number of rooms metered and the number of days that they were metered. Table 6.15 shows kitchen energy consumption which 
TABLE 6.14. Average Energy Consumption Per Available Room/Per Day (energy use in Btu) (a)

\begin{tabular}{|c|c|c|c|c|}
\hline Facility & Heating & Cooling & DHW & $\begin{array}{l}\text { Lighting }+ \\
\text { Wall Outlets } \\
\end{array}$ \\
\hline $\begin{array}{l}\text { Radisson, } \\
\text { Atlanta }\end{array}$ & $\begin{array}{r}33,347 \\
(126)\end{array}$ & $\begin{array}{r}64,984 \\
(126)\end{array}$ & $\begin{array}{r}22,163 \\
(126)\end{array}$ & $\begin{array}{l}3,290 \\
(126)\end{array}$ \\
\hline $\begin{array}{l}\text { La Quinta, } \\
\text { Corpus Christi }\end{array}$ & $\begin{array}{r}9,673 \\
(32)\end{array}$ & $\begin{array}{r}26,329 \\
(32)\end{array}$ & $(32)$ & $\begin{array}{r}12,969 \\
(32)\end{array}$ \\
\hline Kahler Motel & $\begin{array}{r}318,477 \\
(35)\end{array}$ & $\begin{array}{r}15,437 \\
(35)\end{array}$ & $\begin{array}{r}18,975 \\
(126)\end{array}$ & $\begin{array}{r}7,449 \\
(30)\end{array}$ \\
\hline $\begin{array}{l}\text { Radisson, } \\
\quad \text { Arizona }\end{array}$ & -- & $\begin{array}{r}63,136 \\
(81)\end{array}$ & $\begin{array}{l}2,229 \\
(209)\end{array}$ & - \\
\hline $\begin{array}{l}\text { La Quinta, } \\
\text { San Antonio }\end{array}$ & $\begin{array}{r}49,923 \\
(3)\end{array}$ & $\begin{array}{r}30,607 \\
(128)\end{array}$ & $\begin{array}{r}31,339 \\
(128)\end{array}$ & $\begin{array}{r}8,326 \\
(3)\end{array}$ \\
\hline Woodstock Inn & $\begin{array}{r}458,415 \\
(121)\end{array}$ & $\begin{array}{r}28,939 \\
(121)\end{array}$ & $\begin{array}{r}14,501 \\
(121)\end{array}$ & $\begin{array}{r}5,157 \\
(1)\end{array}$ \\
\hline
\end{tabular}

\footnotetext{
(a) Daily energy consumption for the guest rooms is the product of energy consumption/room and the number of rooms in the facility. The number in parentheses is the number of rooms metered in the facility. Available rooms are defined as guest rooms metered regardless of whether they are occupied.
}

has been normalized by the number of meals served. The number of meals served as well as the number of days metered are shown to allow calculation of average daily energy consumption. Table 6.16 shows energy consumption for laundry services in the hotels/motels where those facilities exist and were metered. Table 6.17 shows total energy consumption for those facilities. Unfortunately, total energy consumption by fuel type, is not available for all the hotels. In addition, annual energy consumption for three of the facilities was not collected. 


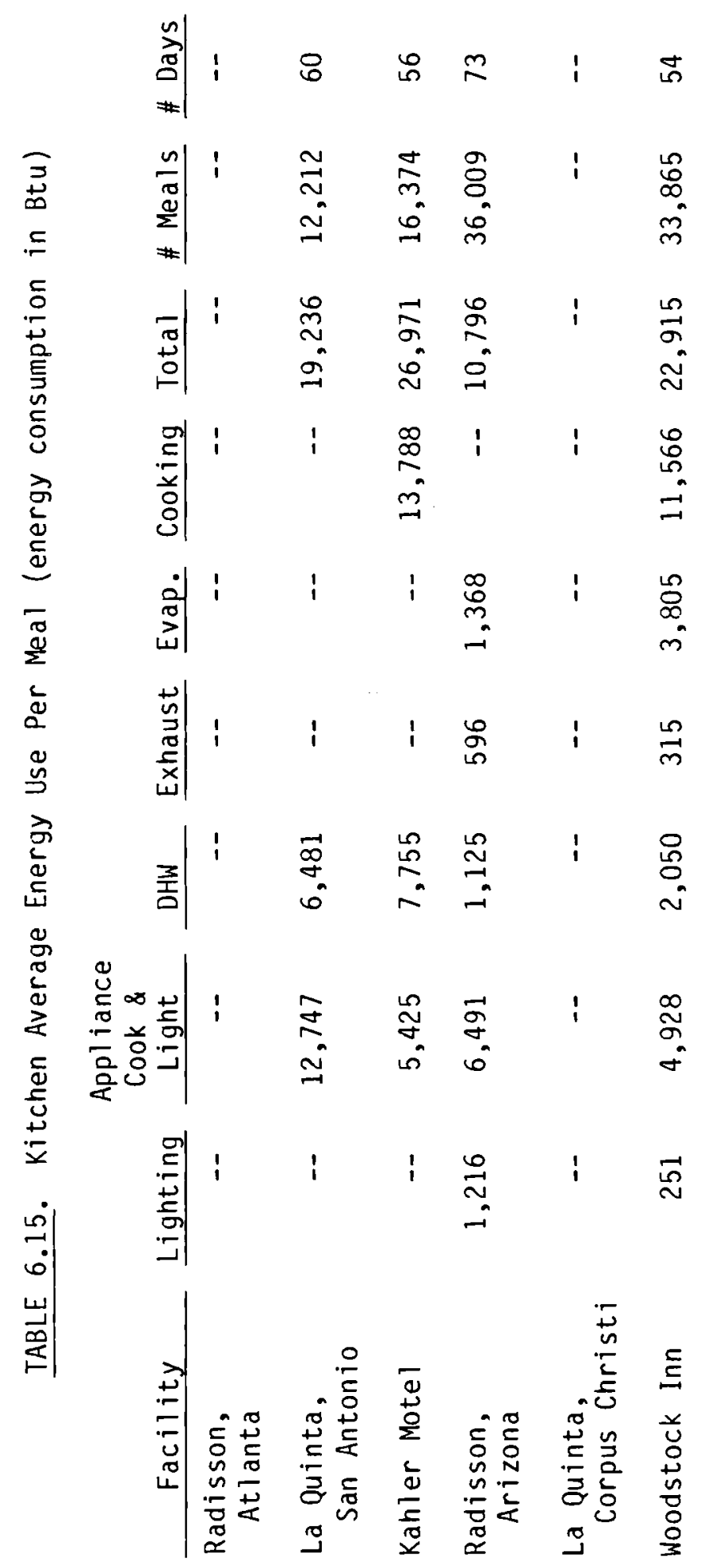


TABLE 6.16. Laundry Energy Use In Btu Per Available Room/Per Day

\begin{tabular}{|c|c|c|c|c|c|c|}
\hline Facility & Dryers & $\begin{array}{l}\text { Lights/ } \\
\text { Outlets/ } \\
\text { Apl. }\end{array}$ & Hot Water & Total & \# Rooms & $\begin{array}{l}\text { Avail. } \\
\text { Rooms }\end{array}$ \\
\hline Radisson, Atlanta & $\overline{14,188}$ & 4,220 & 7,987 & 26,395 & 390 & 8190 \\
\hline La Quinta (C.C.) & -- & -- & -- & -- & -- & -- \\
\hline Kahler Motel & -- & -- & -- & -- & -- & -- \\
\hline Radisson, Ariz. & 6,094 & -- & 5,933 & 12,027 & 209 & 15,257 \\
\hline La Quinta, S.A. & 10,186 & -- & 5,398 & 15,584 & 200 & 11,800 \\
\hline
\end{tabular}

\subsection{SEATTLE CITY LIGHT}

Seattle City Light has studied end-use energy consumption in commercial buildings in Seattle. A list of the facilities metered, by building type, alone with the building size and annual energy consumption are shown below in Table 6.18.

Seattle City Light is still collecting and processing the data for these facilities and end-use data for public release will not be ready for another year. However, a sample of the data collected is shown below in Figure 6.1 which graphically illustrates average hourly end-use energy consumption by month for the $15,000 \mathrm{sq} f t$ office building. In addition, a numeric listing of average hourly end-use energy consumption for the month of December is provided.

End-use data for a limited part of the year on two of the buildings listed in Table 6.18 have already been published as part of a field test report of Seattle City Light's data acquisition system and procedures. The field test report covers the six story office building show in Figure 6.1 and the 23,000 sq ft retail store. Data for only 44 days are available for the retail $51,712 \mathrm{kWh}$, cooling $-13,770 \mathrm{kWh}$, ventilation $-7,445 \mathrm{kWh}$, heating $-7,170 \mathrm{kWh}$, and other $-5,861 \mathrm{kWh}$. Total energy consumption for this winter period was $85,958 \mathrm{dkWh}$. 


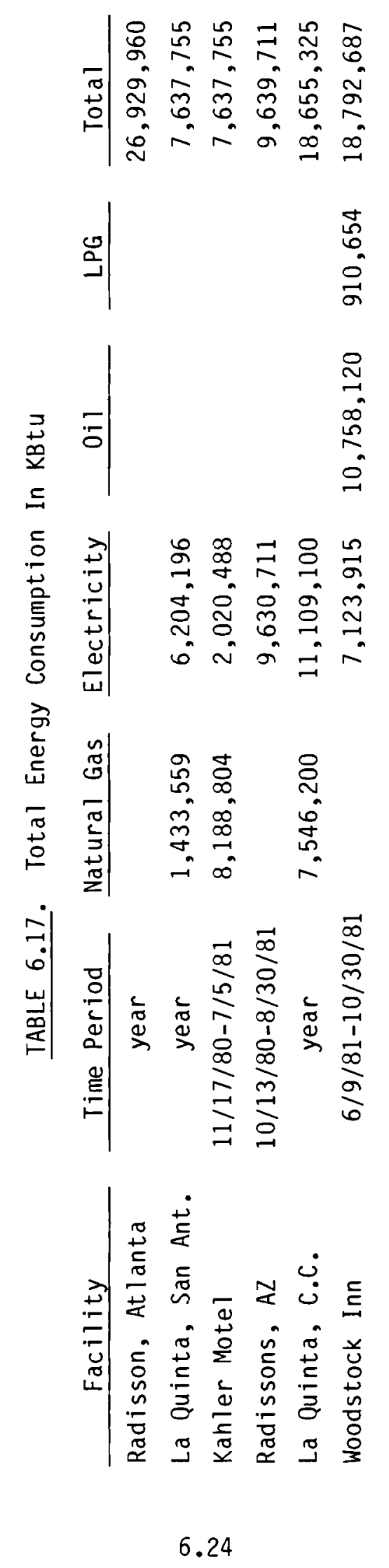


IABLE 6.18. Seattle City Light Metered Facilities

\begin{tabular}{|c|c|c|c|}
\hline Building Class & Floor Area & Stories & $\begin{array}{c}1983 \text { Electric } \\
\text { (in KBtu) }\end{array}$ \\
\hline retail & 22,000 & 1 & $2,517,565$ \\
\hline retail & 35,781 & 1 & $2,952,036$ \\
\hline grocery & 14,768 & 1 & $5,241,548$ \\
\hline grocery & 23,040 & 1 & $4,923,730$ \\
\hline office & 82,306 & 6 & $6,164,901$ \\
\hline office & 15,000 & 3 & $1,059,941$ \\
\hline restaurant & 1,128 & 1 & 849,427 \\
\hline restaurant & 3,250 & 1 & $1,152,911$ \\
\hline multifamily & 9,059 & 13 units & 392,355 \\
\hline mult if amily & 9,059 & 13 units & 405,222 \\
\hline mult if amily & 8,730 & 12 units & 357,054 \\
\hline
\end{tabular}

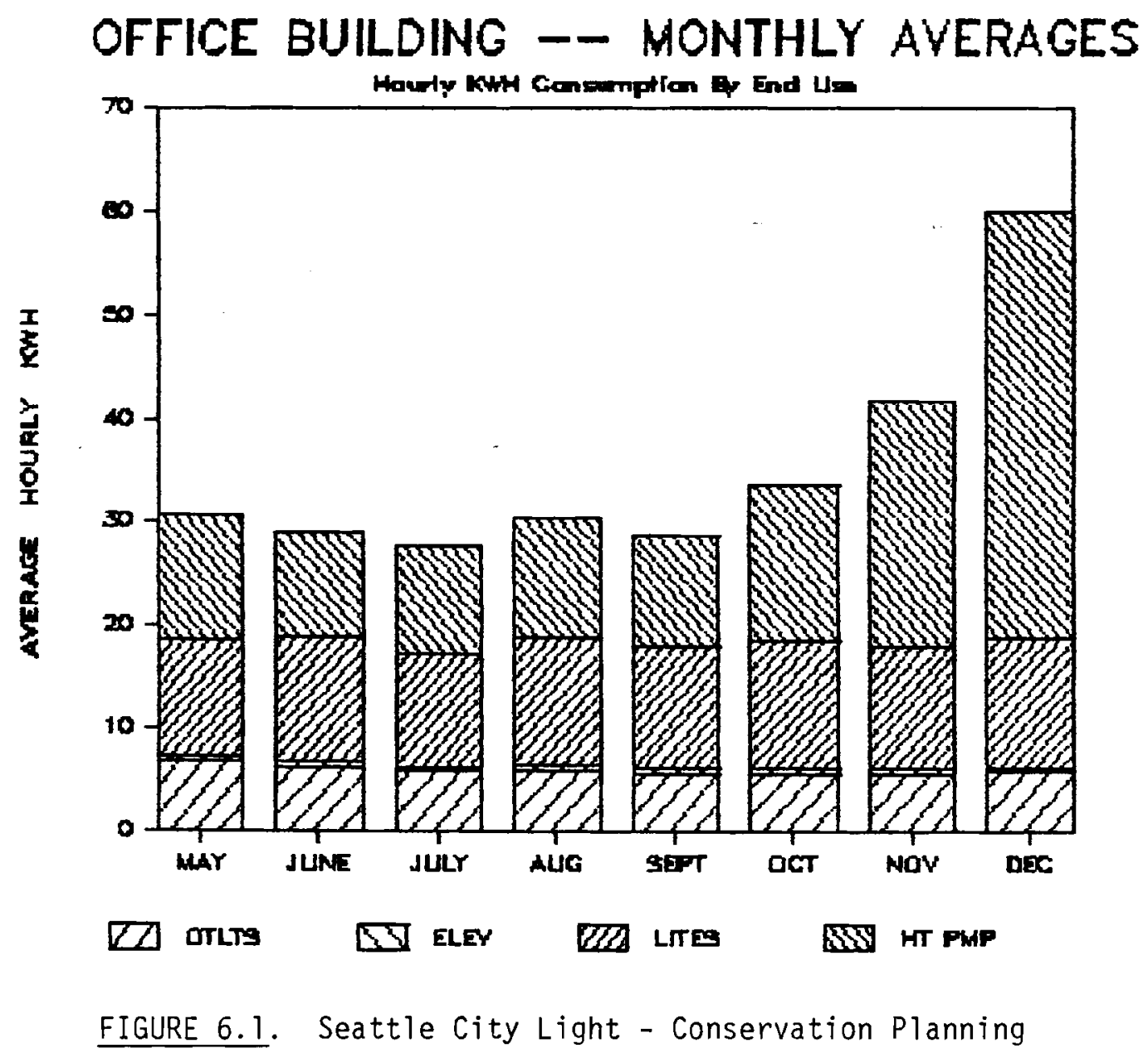




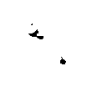

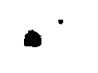

$\checkmark$ 
APPENDIX A

SURVEY 
4

- 


\section{COMMERCIAL BUILDING DATA INQUIRY FORM}

The purpose of this brief questionnaire is to develop an inventory of end-use energy metering efforts for commercial buildings. Responses from this survey will be used to identify sources of metered data to include in the hourly end-use data base maintained by Battelle. The data base is maintained in the public domain.

Name:

Phone:

Affiliation: Title:

Address:

Are you interested in commercial building energy use data?

No Yes

If so, please briefly describe interest:

IF YOU KNOW OF ANY DATA COLLECTION EFFORTS, COMPLETE THE FOLLOWING QUESTIONS Name of project/organization:

Contact person and address:

Phone number:

Type of commercial buildings:

Location and number of buildings:

Period of data collection:

TYPE OF DATA COLLECTED

- Total consumption only

- Consumption by end-use

- Building characteristics

- Building occupancy

- Building operation

- Building microclimate

- Equipment performance

DATA AVAILABILITY

- Public domain

- Proprietary
METERING TECHNIQUE

- Manual records

- Strip chart recorders

- Utility demand meters

- Microprocessor

TIME RESOLUTION OF DATA

- Sub-hourly

- Hourly

- Daily

Titles and sources of documents describing data base:

IF YOU KNOW OF ANY OTHER DATA BASES, PLEASE TURN THE PAGE

Return to: James Heidell, Battelle, Pacific Northwest Laboratory, P.O. Box 999,

Richland, WA 99352, (509) 376-0134 
IF YOU KNOW OF ANY DATA COLLECTION EFFORTS, COMPLETE THE FOLLOWING QUESTIONS Name of project/organization:

Contact person and address:

Phone number:

Type of commercial buildings:

Location and number of buildings:

Period of data collection:

TYPE OF DATA COLLECTED

- Total consumption only

- Consumption by end-use

- Building characteristics

- Building occupancy

- Building operation

- Building microclimate

- Equipment performance

DATA AVAILABILITY

- Public domain

- Proprietary
METERING TECHNIQUE

- Manual records

- Strip chart recorders

- Utility demand meters

- Microprocessor

\section{TIME RESOLUTION OF DATA}

- Sub-hourly

- Hourly

- Daily

Titles and sources of documents describing data base:

IF YOU KNOW OF ANY DATA COLLECTION EFFORTS, COMPLETE THE FOLLOWING QUESTIONS Name of project/organization:

Contact person and address:

Phone number:

Type of commercial buildings:

Location and number of buildings:

Period of data collection:

\begin{tabular}{l} 
TYPE OF DATA COLLECTED \\
\hline - Total consumption only \\
- Consumption by end-use \\
- Building characteristics \\
- Building occupancy \\
- Building operation \\
- Building microclimate \\
- Equipment performance \\
DATA AVAILABILITY \\
- Public domain \\
- Proprietary
\end{tabular}

\begin{tabular}{l} 
METERING TECHNIQUE \\
\hline - Manual records \\
- Strip chart recorders \\
- Utility demand meters \\
- Microprocessor
\end{tabular}

TIME RESOLUTION OF DATA

- Sub-hourly

- Hourly

- Daily

Titles and sources of documents describing data base: 
Dear Mr. Generic:

This letter is written to request information on end-use energy consumption for commercial buildings. This information is being collected to create a publicly available hourly end-use data base to support research and conservation efforts relating to commercial buildings. I would appreciate your completing the brief questionnaire attached, and returning it in the enclosed post paid envelope.

The hourly end-use data base for commercial buildings is being assembled by Battelle, Pacific Northwest Laboratory for the U.S. Department of Energy. Our immediate goal is to inventory presently available sources of commercial building energy consumption data, preferably by hour and end-use. However, enduse energy consumption aggreqated over other time periods is also of interest. You can assist in these efforts by identifying data sources which you have knowledge of, and/or describing your interest in the data that this project can provide. In addition, if you know of other organizations or people who have collected end-use data, or would like access to such data, please identify them on the attached survey.

Enclosed you will find a list of metered commercial buildings which we have a knowledge of, as well as the questionnaire. Please take a few moments to review this material and complete the survey form. If you have any questions about the survey, the data base, or would like information about accessing the data base, please feel free to contact Jim Heidell at 509-376-4738.

Sincerely,

Richard P. Mazzucchi

Senior Research Engineer

Commercial Buildings Energy Use and

Design Program

JAH:wma

Enclosure 
$+$

$-$

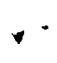

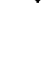


PRELIMINARY INVENTORY OF END-USE METERED DATA BASES

The results from a preliminary survey of end-use energy data collection efforts are shown in Table 1. While there is a significant amount of information related to audits and total energy use for commercial buildings, few of the existing energy use data bases contain hourly end-use metered data. Twenty seven data bases containing end-use data have been identified. Eleven of those data bases contain information on commercial buildings other than schools, hospitals and public buildings. Six of the data bases are identified as containing hourly data. Brief descriptions of some of the projects containing hourly end-use data are provided on the back of this page.

\section{Table 1 Commercial Buildings Data Bases}

\section{SOURCE}

Amer. Hote1 \& Motel Assoc. Arkansas State Energy Office Cal ifornia Energy Comm. California Energy Comm. District of Columbia Energy Unit Electric Power Research Inst. Enercon, Ltd. Georgia Office of Energy Idaho Office of Energy Iowa Energy Policy Council Kansas Energy Office KT Dept. of Natural Resources MI Fuel \& Energy Management Comm Nebraska Energy Office Nevada Department of Energy N.H. Governor's Counc il Energy New Mexico Dept. of Energy N.Y. State Energy Office Oregon Department of Energy PA Governor's Energy Counc il U.S. Postal Service

W.V. Governor's Office Economic \& Community Development National Solar Data Network National Restaurant Assoc. Passive Solar Commercial Bldg PURPA filings

Pacific Northwest Laboratory

COMMENTS

$\frac{\text { BUILDING }}{\underline{\text { TYPE }}} \quad \stackrel{\text { DATA }}{\text { TYPE }}$

Hotels

150 public agencies $M, E$

$300 \mathrm{C}$

$500 \mathrm{C}$

$\mathrm{S}, \mathrm{H}$

2800 buildings

$\mathrm{S}, \mathrm{H}$

$1,400 \mathrm{~S}, \mathrm{H}, \mathrm{O}$

$1144 \mathrm{~S}, 66 \mathrm{H}$

$2000 \mathrm{~S}, \mathrm{H}$

$3000 \mathrm{H}, \mathrm{S}$

$1500 \mathrm{~S}, \mathrm{H}$

$\mathrm{S}, \mathrm{H}$

$2000 \mathrm{~S}, \mathrm{H}, \mathrm{P}$

18 state bldgs

$400 \mathrm{~S}, \mathrm{H}$

$3565 \mathrm{~S}, \mathrm{H}, \mathrm{P}$

$\mathrm{S}, \mathrm{H}, \mathrm{P}$

$4000 \mathrm{~S}, \mathrm{H}, \mathrm{P}$

$700 \mathrm{~S}, \mathrm{H}$

7 post offices

$2650 \mathrm{~S}, \mathrm{H}, \mathrm{P}$
$\mathrm{C}$
7 restaurants
$21 \mathrm{C}$
$\mathrm{C}$
0

$E, F, A$

$H, E, A$

$H, E, A$

$H, E, A$

$\mathrm{H}$

$H, E, A$

$E$

$E, F, A$

$E, F, A$

$E, F, A$

$E, F, A$

$E, F, A$

$E, F, A$

$E, F, A$

$E, F, A$

$E, F, A$

$F, A$

$E, F, A$

$E, F, A$

$E, F, A$

$E$
$E, F, A$ by survey

$E, F, A$ not automated

$E, F, A$ automated

$E, F, A \quad$ hour-of-use

Data Type

H- hourly

$M$ - monthly

$E$ - end-use

$F$ - by fuel type

$G$ - energy use, not specified

A - building specifications/audit
3,500 meters
KEY: $\quad \frac{\text { Building Type }}{S-\text { school }}$
$H$ - hospital
- public
O - office


The Public Utility Regulatory Policy Act (PURPA) data base contains total hourly electric energy consumption for some commercial buildings. The data includes office buildings with and without electric heating, and multifamily buildings. The data base does not contain end-use information and data are typically aggregated and reported as typical hourly and peak hourly consumption for a building sector. In most cases, there is incomplete documentation of building characteristics.

\section{Passive Solar Buildings Data Bases}

The Passive Solar Commercial Buildings Program is collecting hourly end-use data from passive solar buildings. An unfortunate aspect of the Passive Solar Commercial Buildings data base is that the buildings were not instrumented with similar metering equipment. Another solar related data base is the National Solar Data Network. (Battelle is concentrating on "typical" commercial buildings, and not specially designed passive solar buildings.)

American Hote 1 and Motel Data Base

The American Hotel and Motel metering data base is incomplete. The data base contains approximately two weeks of hourly end-use data for the summer and winter seasons for each building.

\section{National Restaurant Association Data Base}

The National Restaurant Association project, part of Battelle Pacific Northwest Laboratory's Commercial Buildings Program, recently began collecting fifteen minute end-use and micro-climate data for seven restaurants in Pennsylvania. The duration of data collection will be one year.

\section{BECA Data Base}

The Building Energy Conservation Analysis (BECA) data base is maintained by Lawrence Berkeley Laboratory. The data base is not focused upon empirical hourly end-use data and concentrates on more aggregated data.

In addition to these projects, there are a number of metering projects of single buildings. One of these projects is the Norris Cotton Federal office Building in Manchester, New Hampshire. The data base resulting from this metering project includes hourly end-use records. The building is atypical since it was designed to demonstrate the energy use resulting from a range of mechanical and lighting systems and envelope configurations. A second project is the metering of Georgia Power's office building. The office building is another example of passive solar design. 
APPENDIX B

ORGANIZATIONS AND PEOPLE CONTACTED 
$-$

$-$

$\cdots$

. 
APPENDIX B

ORGANIZATIONS AND PEOPLE CONTACTED

This appendix contains the list of organizations contacted during the inventory of existing end-use energy metering projects. The names of individuals contacted have been omitted to avoid disruptions to their work due to further contacts. Readers desiring more information on the contacts should write to Pacific Northwest Laboratory.

The list of organizations contacted have been divided into seven categories: National Laboratory or university, state or local government agency, federal government agency, A\&E or other consultant, equipment manufacturer, utility, and trade or professional organization. The organizations contacted are listed in alphabetical order and divided into seven tables sorted by type of organization. The "ID" listed in the following tables corresponds to the "ID" assigned to each metering project cataloged. 
LIST OF CONTACTS FOR COMMERCIAL BUILDINGS METERED END-USE DATA INVENTORY

\begin{tabular}{|c|c|c|}
\hline ID & TYPE & COMPANY NAME \\
\hline 86 & $\mathrm{R}$ & ENERGY \& ENVIRONMENTAL SYSTEMS DIVISION \\
\hline 46 & $\mathrm{R}$ & ATMOSPHERIC SCIENCES RESEARCH CENTER STATE UNIVERSITY OF NEW YORK \\
\hline 61 & $\mathrm{R}$ & BATTELLE COLUMBUS LABORATORIES \\
\hline 58 & $\mathrm{R}$ & BATTELLE COLUMBUS LABORATORIES \\
\hline 26 & $\mathrm{R}$ & STUDIES, ENGINEERING QUADRANGLE H 104 \\
\hline 139 & $\mathrm{R}$ & CENTER FOR ENERGY POLICY AND \\
\hline 55 & $\mathrm{R}$ & ENGINEERING, OHIO STATE UNIVERSITY \\
\hline 151 & $\mathrm{R}$ & LAWRENCE BERKELEY LABORATORY \\
\hline 91 & $\mathrm{R}$ & LAWRENCE BERKELEY LABORATORY (LBL) \\
\hline 62 & $\mathrm{R}$ & LOS ALMOS SCIENTIFIC LABORATORY \\
\hline 13 & $\mathrm{R}$ & MIAMI UNIVERSITY \\
\hline 57 & $\mathrm{R}$ & NEW MEXICO ENERGY RESEARCH AND DEVELOPMENT INSTITUTE \\
\hline 21 & $\mathrm{R}$ & OAK RIDGE NATIONAL LABORATORY \\
\hline 85 & $\mathrm{R}$ & OAK RIDGE NATIONAL LABORATORY \\
\hline 79 & $\mathrm{R}$ & ORNL - OAK RIDGE NATIONAL \\
\hline 118 & $\mathrm{R}$ & PACIFIC NORTHWEST LABORATORY \\
\hline 117 & $\mathrm{R}$ & PACIFIC NORTHWEST LABORATORY \\
\hline 87 & $\mathrm{R}$ & ROCKWELL INTERNATIONAL/ETEC \\
\hline 89 & $\mathrm{R}$ & SOLAR ENERGY RESEARCH INSTITUTE \\
\hline 158 & $\mathrm{R}$ & SOLAR ENERGY RESEARCH INSTITUTE \\
\hline 159 & $\mathrm{R}$ & SOLAR ENERGY RESEARCH INSTITUTE \\
\hline 143 & $\mathrm{R}$ & SUNYAB \\
\hline 162 & $\mathrm{R}$ & UNIVERSITY OF MANITOBA \\
\hline 154 & $\mathrm{R}$ & UNIVERSITY OF MANITOBA \\
\hline 150 & $\mathrm{R}$ & UNIVERSITY OF MANITOBA \\
\hline 153 & $\mathrm{R}$ & UNIVERSITY OF MICHIGAN \\
\hline 95 & $\mathrm{R}$ & UNIVERSITY OF TEXAS AT AUSTIN DEPARTMENT OF MECHANICAL ENGINEERING \\
\hline 146 & $\mathrm{R}$ & UNIVERSITY OF WASHINGTON \\
\hline 163 & $\mathrm{R}$ & UTAH ENGINEERING EXPER STATION \\
\hline 14 & $\mathrm{R}$ & VICTORIA UNIVERSITY \\
\hline TYPE & $\mathrm{OF} \quad \mathrm{CO}$ & $\begin{array}{l}\mathrm{R}=\text { NATIONAL LABORATORY OR UNIVERSITY } \\
\mathrm{G}=\text { STATE OR LOCAL GOVERNMENT AGENCY } \\
\mathrm{F}=\text { FEDERAL GOVERNMENT AGENCY } \\
\mathrm{C}=\text { A\&E OR OTHER CONSULTANT } \\
\mathrm{E}=\text { EQUIPMENT MANUFACTUER } \\
\mathrm{U}=\text { UTILITY } \\
\mathrm{T}=\text { TRADE/PROFESSIONAL ASSOCIATION }\end{array}$ \\
\hline
\end{tabular}


LIST OF CONTACTS FOR COMMERCIAL BUILDINGS METERED END-USE DATA INVENTORY

\begin{tabular}{|c|c|c|}
\hline ID & TYPE & COMPANY NAME \\
\hline 33 & G & ALABAMA DEPARTMENT OF ENERGY \\
\hline 41 & G & ALASKA POWER ADMINISTRATION \\
\hline 27 & G & ARIZONA OFFICE OF ENERGY \\
\hline 28 & G & OFFICE OF ECONOMIC PLANNING \&DEVELOPMENT \\
\hline 29 & G & CALIFORNIA ENERGY COMMISSION \\
\hline 66 & G & CALIFORNIA ENERGY COMMISSION \\
\hline 173 & G & CALIFORNIA ENERGY COMMISSION CONSERVATION DIVISION \\
\hline 109 & G & COLORAD OFFICE OF ENERGY CONSERVATION \\
\hline 30 & G & COLORADO OFFICE OF ENERGY \\
\hline 107 & G & COLORADO OFFICE OF ENERGY CONSERVATION \\
\hline 110 & G & D.C. ENERGY OFFICE \\
\hline 108 & G & DEPARTMENT OF NATURAL RESOURCES, TECHNOLOGY TRANSFER DIVISION \\
\hline 113 & G & DOQ DIVISION OF STATE ENERGY \\
\hline 161 & G & (DEP. OF PLANNING \& ECONOMIC DEVELOPMENT \\
\hline 34 & G & ILLINOIS DEPARTMENT OF ENERGY AND NATURAL RESOURCES \\
\hline 32 & G & IOWA POLICY COUNCIL \\
\hline 115 & G & KENETUCKY ENERGY CABINET \\
\hline 35 & G & MAINE OFFICE OF ENERGY \\
\hline 116 & G & N.H. GOVERNOR'S ENERGY OFFICE \\
\hline 36 & G & NEW YORK STATE ENERGY OFFICE \\
\hline 112 & G & NEW YORK STATE ENERGY OFFICE \\
\hline 38 & G & OFFICE OF ENERGY RESOURCES \\
\hline 111 & G & OFFICE OF POLICY \& MANAGEMENT, ENERGY DIVISION, STATE OF CONNECTICUT \\
\hline 77 & G & OHIO DIVISION OF ENERGY \\
\hline 83 & G & OKLAHOMA CORPORATION COMMIS- ION \\
\hline 106 & G & STATE OF ARIZONA \\
\hline 37 & G & STATE OF COLORADO, OFFICE OF ENERGY CONSERVATION \\
\hline 39 & G & DEPARTMENT OF NATURAL RESOURCES \\
\hline 40 & G & STATE OF MICHIGAN, DEPARTMENT OF COMMERCE, ENERGY ADMINISTRATION \\
\hline 12 & G & U.S. POSTAL SERVICE \\
\hline 84 & G & WASHINGTON STATE ENERGY OFFICE \\
\hline TYPE & $\mathrm{CC}$ & $\begin{array}{l}\text { TACT }:=\text { NATIONAL LABORATORY OR UNIVERSITY } \\
\text { G }=\text { STATE OR LOCAL GOVERNMENT AGENCY } \\
\mathrm{F}=\text { FEDERAL GOVERNMENT AGENCY } \\
\mathrm{C}=\text { A\&E OR OTHER CONSULTANT } \\
\mathrm{E}=\text { EQUIPMENT MANUFACTUER } \\
\mathrm{U}=\text { UTILITY } \\
\mathrm{T}=\text { TRADE/PROFESSIONAL ASSOCIATION }\end{array}$ \\
\hline
\end{tabular}


LIST OF CONTACTS FOR COMMERCIAL BUILDINGS METERED END-USE DATA INVENTORY

\begin{tabular}{|c|c|c|c|}
\hline ID & TYPE & COMPANY NAME & \\
\hline 142 & $\mathrm{~F}$ & BONNEVILLE POWER ADMIN. & \\
\hline 105 & $\mathrm{~F}$ & BONNEVILLE POWER ADMINISTRATION (BPA) & \\
\hline 42 & $\mathrm{~F}$ & DIV.OF POWER RESOURCE PLANNINGTENNESSEE VALLEY & AUTHORITY \\
\hline 72 & $\mathrm{~F}$ & GSA - GENERAL SERVICES $\quad$ ADMINISTRATION & \\
\hline 145 & $\mathrm{~F}$ & NATIONAL BUREAU OF STANDARDS & \\
\hline 71 & $\mathrm{~F}$ & NATIONAL BUREAU OF STANDARDS & \\
\hline 97 & $\mathrm{~F}$ & TENNESSEE VALLEY AUTHORITY & \\
\hline 15 & $\mathrm{~F}$ & U.S. DOE CHICAGO OPERATIONS OF & \\
\hline & $\mathrm{F}$ & U.S. POSTAL SERVICE & \\
\hline 98 & $\mathrm{~F}$ & U.S. POSTAL SERVICE, & DEPARTMENT \\
\hline 160 & $\mathrm{~F}$ & UNITED STATES AIR FORCE & \\
\hline
\end{tabular}


LIST OF CONTACTS FOR COMMERCIAL BUILDINGS METERED END-USE DATA INVENTORY

\begin{tabular}{|c|c|c|}
\hline ID & TYPE & COMPANY NAME \\
\hline 142 & $\mathrm{~F}$ & BONNEVILLE POWER ADMIN. \\
\hline 105 & $\mathrm{~F}$ & BONNEVILLE POWER ADMINISTRATION (BPA) \\
\hline 42 & $\mathrm{~F}$ & DIV.OF POWER RESOURCE PLANNINGTENNESSEE VALLEY AUTHORITY \\
\hline 72 & $\mathrm{~F}$ & GSA - GENERAL SERVICES $\quad$ ADMINISTRATION \\
\hline 145 & $\mathrm{~F}$ & NATIONAL BUREAU OF STANDARDS \\
\hline 71 & $\mathrm{~F}$ & NATIONAL BUREAU OF STANDARDS \\
\hline 97 & $\mathrm{~F}$ & TENNESSEE VALLEY AUTHORITY \\
\hline 15 & $\mathrm{~F}$ & U.S. DOE CHICAGO OPERATIONS OF \\
\hline 7 & $\mathrm{~F}$ & U.S. POSTAL SERVICE \\
\hline 98 & F & R.E. \& BUILDINGS DEPARTMENT \\
\hline 160 & $\mathrm{~F}$ & UNITED STATES AIR FORCE \\
\hline \multicolumn{3}{|c|}{$\begin{array}{ll}\text { TYPE OF CONTACT: } & \mathrm{R}=\text { NATIONAL LABORATORY OR UNIVERSITY } \\
\mathrm{G} & =\text { STATE OR LOCAL GOVERNMENT AGENCY } \\
\mathrm{F} & =\text { FEDERAL GOVERNMENT AGENCY } \\
\mathrm{C} & =\text { A\&E OR OTHER CONSULTANT } \\
\mathrm{E} & =\text { EQUIPMENT MANUFACTUER } \\
\mathrm{U} & =\text { UTILITY } \\
\mathrm{T} & =\text { TRADE/PROFESSIONAL ASSOCIATION }\end{array}$} \\
\hline
\end{tabular}


LIST OF CONTACTS FOR COMMERCIAL BUILDINGS METERED END-USE DATA INVENTORY

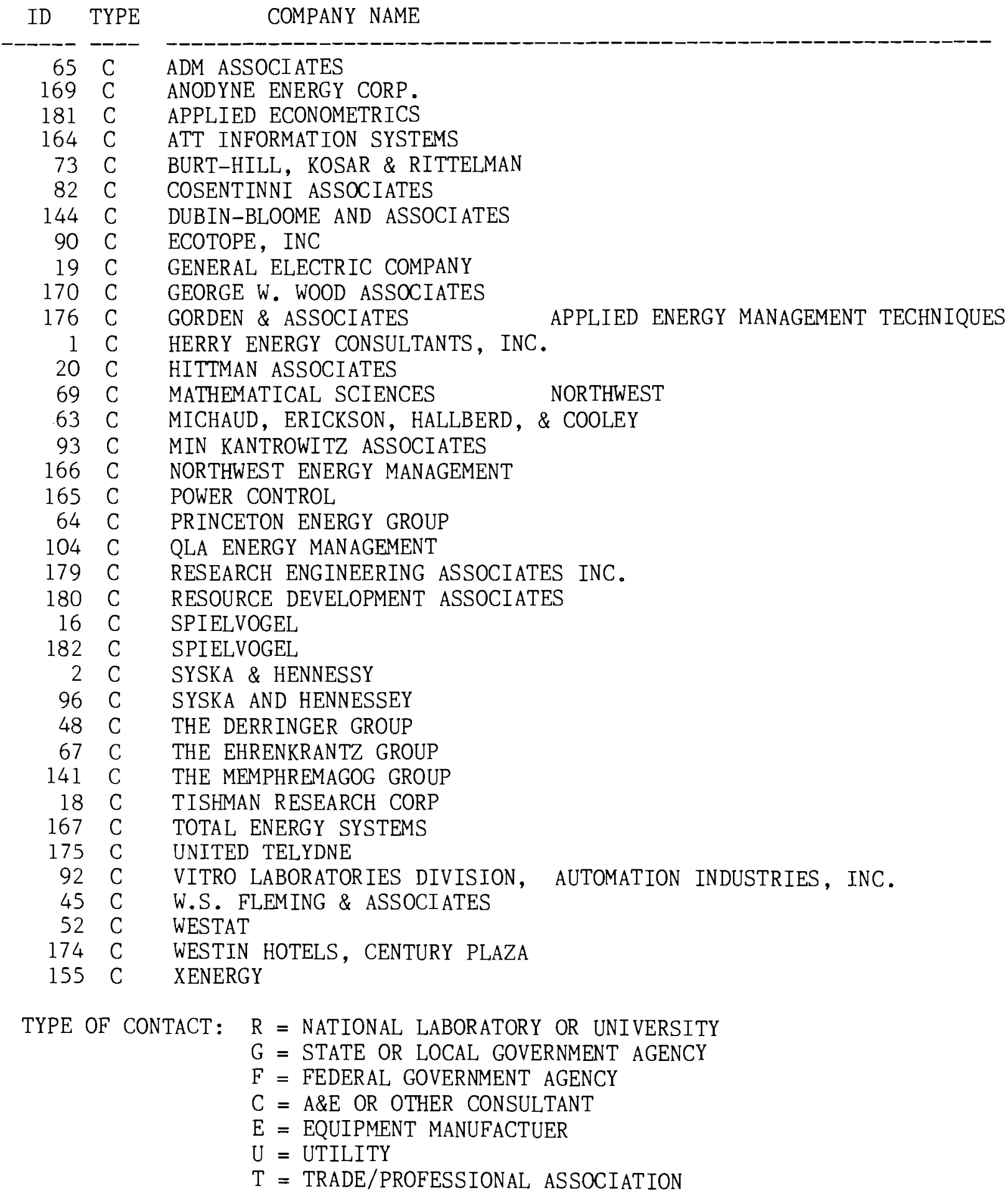


LIST OF CONTACTS FOR COMMERCIAL BUILDINGS METERED END-USE DATA INVENTORY

$\begin{array}{rrl}\text { ID } & \text { TYPE } & \\ 25 & \text { E } & \text { COMPANY NAME } \\ 183 & \text { E } & \text { CALMONT TECHNOLOGIES, INC. } \\ 137 & \text { E } & \text { CARRIER } \\ 23 & \text { E } & \text { EXCELL DDC } \\ 80 & \text { E } & \text { HEATH ENGINEERING } \\ 4 & \text { E } & \text { JOHNSON CONTROLS } \\ 100 & \text { E } & \text { OWENS CORNING } \\ 22 & \text { E } & \text { SCALLOP THERMAL MANAGEMENT } \\ 24 & \text { E } & \text { THE TRANE CO } \\ \text { TYPE OF CONTACT: }: \quad \text { R } & =\text { NATIONAL LABORATORY OR UNIVERSITY } \\ \text { G } & =\text { STATE OR LOCAL GOVERNMENT AGENCY } \\ \text { F } & =\text { FEDERAL GOVERNMENT AGENCY } \\ \text { C } & =\text { A\&E OR OTHER CONSULTANT } \\ \text { E } & =\text { EQUIPMENT MANUFACTUER } \\ \text { U } & =\text { UTILITY } \\ \text { T } & =\text { TRADE/PROFESSIONAL ASSOCIATION }\end{array}$


LIST OF CONTACTS FOR COMMERCIAL BUILDINGS METERED END-USE DATA INVENTORY

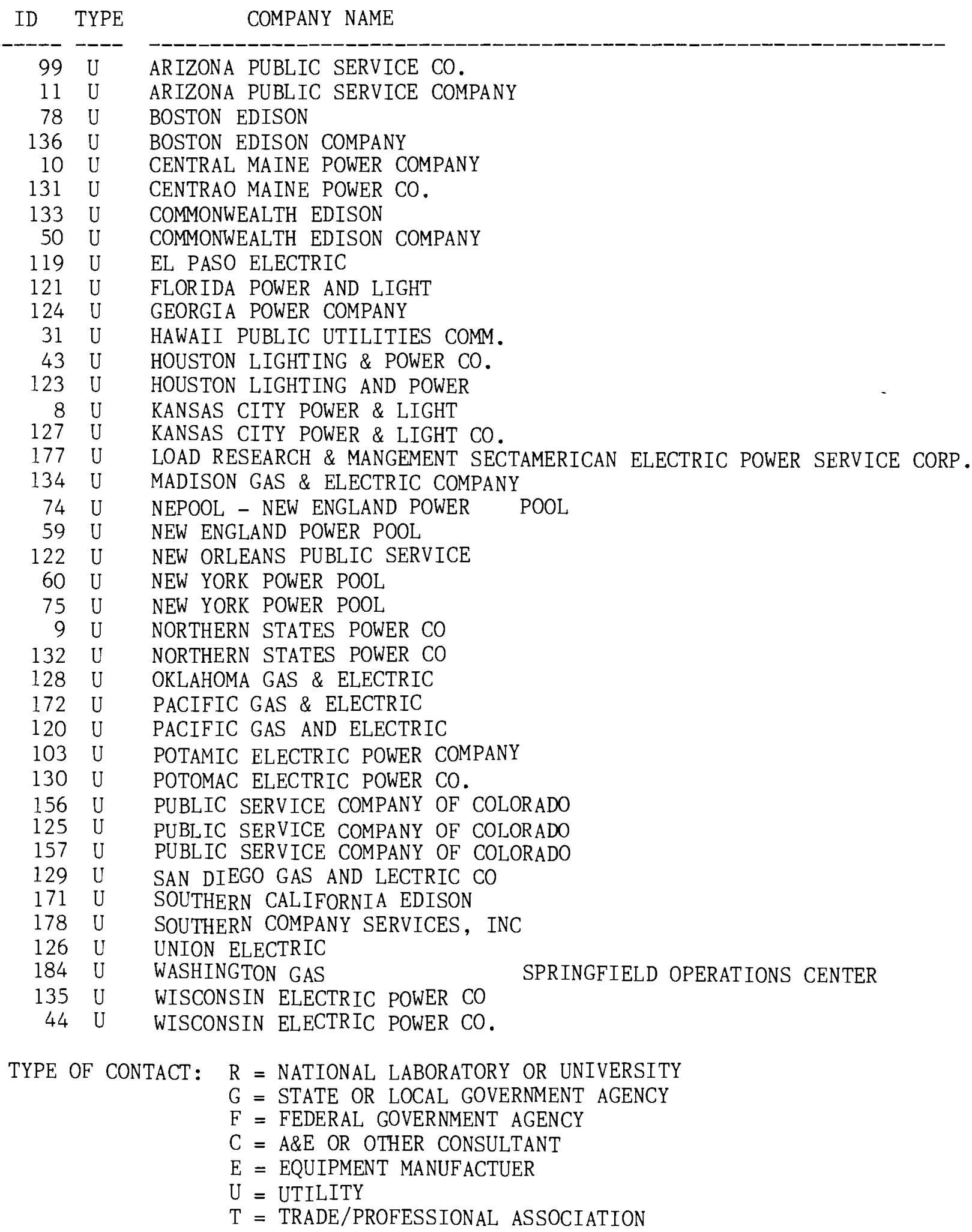


LIST OF CONTACTS FOR COMMERCIAL BUILDINGS METERED END-USE DATA INVENTORY

\begin{tabular}{|c|c|c|c|c|}
\hline ID & TYPE & COMPANY NAME & & \\
\hline 68 & $\mathrm{~T}$ & AMERICAN CONSULTING ENGINEERS & COUNCIL (ACEC) & \\
\hline 101 & $\mathrm{~T}$ & AMERICAN CONSULTING ENGINEERS & COUNCIL (ACEC) & \\
\hline 47 & $\mathrm{~T}$ & AMERICAN HOTEL \& MOTEL ASSOC. & & \\
\hline 53 & $\mathrm{~T}$ & AMERICAN HOTEL \& MOTEL ASSOC. & & \\
\hline 94 & $\mathrm{~T}$ & AMERICAN INSTITUTE OF ARCHITE & CTS & \\
\hline 138 & $\mathrm{~T}$ & ASSOCIATION OF ENERGY ENGINEEI & & \\
\hline 140 & $\mathrm{~T}$ & AUTOMATED PROCEDURES FOR ENGII & NEER ING CONSULTANTS & \\
\hline 76 & $\mathrm{~T}$ & BOMA - BUILDING OWNERS \& & MANAGERS ASSOCIATION & \\
\hline 88 & $\mathrm{~T}$ & ELECTRIC POWER RESEARCH & INSTITUTE（EPRI） & \\
\hline 49 & $\mathrm{~T}$ & ENERGY MANAGEMENT \& CONTROLS & SOCIETY C/O DRISCOLL \& ASSOCIATES & \\
\hline 168 & $\mathrm{~T}$ & GAS RESEARCH INSTITUTE & FORECASTING AND STRATEGIC PLANNING & GROUP \\
\hline 81 & $\mathrm{~T}$ & GAS RESEARCH INSTITUTE - GRI & & \\
\hline 70 & $\mathrm{~T}$ & ILLUMINATING ENGINEERING & SOCIETY & \\
\hline 102 & $\mathrm{~T}$ & INSTITUTE OF GAS TECHNOLOGY & & \\
\hline 56 & $\mathrm{~T}$ & NATIONAL INSTITUTE OF BUILDINC & GSCIENCES (NIBS) & \\
\hline 149 & $\mathrm{~T}$ & NATIONAL INSTITUTE OF BUILDINC & S SCIENCES & \\
\hline 17 & $\mathrm{~T}$ & NCSBCS & & \\
\hline \multicolumn{5}{|c|}{$\begin{array}{ll}\text { TYPE OF CONTACT: } & \mathrm{R}=\text { NATIONAL LABORATORY OR UNIVERSITY } \\
\mathrm{G} & =\text { STATE OR LOCAL GOVERNMENT AGENCY } \\
\mathrm{F} & =\text { FEDERAL GOVERNMENT AGENCY } \\
\mathrm{C} & =\text { A\&E OR OTHER CONSULTANT } \\
\mathrm{E} & =\text { EQUIPMENT MANUFACTUER } \\
\mathrm{U} & =\text { UTILITY } \\
\mathrm{T} & =\text { TRADE/PROFESSIONAL ASSOCIATION }\end{array}$} \\
\hline
\end{tabular}


APPENDIX C

ANNOUNCEMENTS AND ADVERTISEMENTS 
$\checkmark$

$\star$

$\checkmark$

$-$ 


\section{INDUSTRIAL PROGGRESS}

under high-voltage lines in rural areas, particularly in eastern and southwestern Ontario where the utility proposes to build major new lines.

And for the first time this past summer, Hydro took its demonstrations across international boundaries as New York State Power Authority enlisted the aid of O'Grady and another Hydro community relations officer, Bob Mesman, who combined

\section{REGULATORY POSITIÖNS}

Immediate openings in the Reno-

Tahoe recreational area.

\section{Manager of Audit Division}

Responsible for managing and coordinating the audit staff and program of the Public Service Commission and testifying before the Commission. Accounting degree, CPA and four years of experience with large accounting firm, regulatory body or utility required. Corporate tax experience desirable. Salary to $\$ 42,228$.

\section{Auditor}

Responsible for conducting audits of utilities for the Public Service Commission. Degree in accounting required. Two years of experience with accounting firm, regulatory body or utility required. Corporate tax experience desirable. Salary to $\$ 33,536$.

\section{Manager of Rates and Tarift Division}

Responsible for managing and coordinating the rate and tariff staff of the Public Service Commission and rate design matters before the PSC. Degree in area related to public utility regulation and four years of utility regulatory experience. Two years of rate design background desirable.' Salary to $\$ 35,100$.

\section{No FICA. Excellent benefits}

Send resume to:

Stephen E. Parr, Director Regulatory Operations Public Service Commission 505 East King Street Carson City, NV 89710

(702) 885-3004 spent six weeks traveling the southeastern part of the state discussing safe working practices around high-voltage lines and explaining common biological and environmental effects.

The New York State Power Authority proposes to build a new, 345kilovolt line in the area to carry hydroelectric power imported from another Canadian province, Quebec.

"We try to put things into perspective for the layman by relating the electrical environment of the highvoltage line to the electrical environment found in the average home," said O'Gradv, who has been involved in Hydro's mobile demonstration program since it began in 1980 . "We find that a down-to-earth approach, coupled with demonstrations that people can get personally involved in, clears up a good deal of misunderstanding."

The program includes both indoor and outdoor demonstrations. Outdoors, they begin with the information van parked on an insulating plastic pad directly below energized conductors. The high-voltage lines overhead create an electrostatic field. showing the effects that might be experienced in a worst-case situation with farm equipment operating on the right-of-way.

Normally, of course, no charge would build up on the vehicle. But in this case voltage in the air couples to the van's metal surface and, unable to escape to the ground because of the plastic pads, a small, harmless static charge builds up. At worst, the charge is annoving, but hardly dangerous. It would be comparable to walking across a carpet in a dry room and touching a doorknob.

The indoor demonstrations, popular at country fairs and similar events. use models to create the electric and magnetic ficlds central to the information theme. A Van der Gralf generator, creating a $400,000-V$-electric field. literally raises the hair of participants who volunteer from the audience. Another model, a transformer connected to a copper loop, creates a strong magnetic field demonstrated by magnetizing nails and paper clips.

O'Grady savs there lras been a great deal of interest shown by other utilities in the demonstration program. which won a Canacian public rela- tions society award for communications excellence.

"Manv of these other utilities have sent representatives to see how our program works - some from as far away as Europe, South America, and Japan," he says. With the success of the demonstrations in New York, Ontario Hydro now expects to answer similar requests from other neighboring utilities.
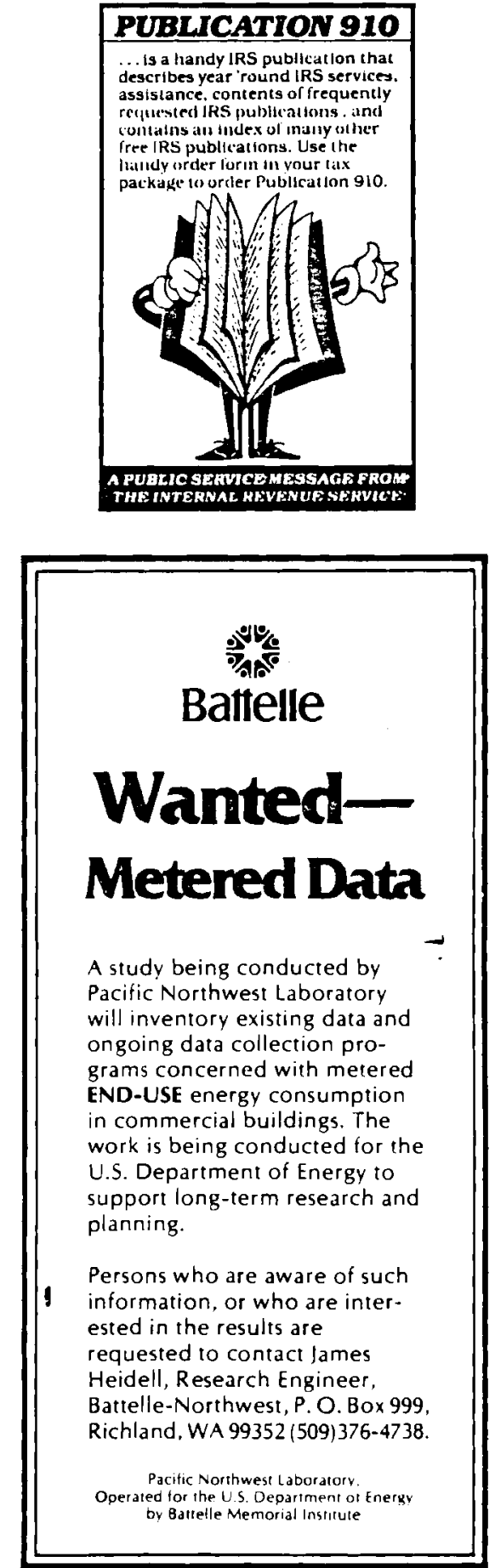


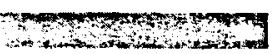

comp. and future in a stable environment. Contact our reps. in conf. at: G. Marshall Assoc., P.O. Box 66083. Chicago, 1 L 60666.

PLUMBING DSNR-Needed by prominent cons. engrg. firm in central FL. Candidate should have 4-6 + yr exp. in the comprehensive design of plumbing and $f$.p. systems integral to inst., commer. and of fice facilities. Ability to function independently and assume project design respon. is essential. Excellent salary and long term growth oppor. in an attractive location. Contact our reps. in conf. at: $\mathbf{G}$. Marshall Assoc., P.O. Box 66083, Chicago. IL 60666 .

PLUMBING ENGR-Position avail. with growing $M / E$ firm in the Midwest. Qualified person should have $6+y r$ exp. in the design of plambing and $f . p$. systems for inst. and comm. projects. Ability to assume project respon. as well as ctiènt liaison also req. Excellent salary and advancernent oppor. Contact our reps in conf. at: G. Marshall Assoc., P.O. Box 66083, Chicago, IL 60666.

SR. MECHANICAL ENGR.-Req. by major cons. $M / E$ in the NE. Degree and PE along with 8-10+ yrs. exp. in dsn. and project direction for HVAC systems integral to large comm., of fice and inst. projects is req. Ability to assume major project respon., maintain ef fective client liaison and provide tech. direction is also req. Firm of fers long term growth and excellent salary in a desirable location. Contact our reps. in conf. at: G. Marshall Assoc., P.O. Box 66083, Chicago, IL 60666.

CHIEF MECHANICAL ENGR.-Position open with major E/A firm in the Midwest. Qualified person must have degree and PE coupled with $12+$ yrs. progressive exp. in dsn. of complete mech. systems for major indust., inst. and comm. facili. ties. Proven exp. in the supv. of dept. staff exceeding 25 professionals along with dsn. and/or supv. of systems incl. HVAC, plumb., process piping and indust. vent. is preferred. Position req. management as well as tech. expertise. Prominent firm offers excellent salary and future. Contact our reps. in conf. at: G. Marshall Assoc., P.O. Box 66083, Chicago, IL 60666

DEPT. MANAGER-Position avail. with Midwest $A / E$. Qualified person must have degree and PE coupled with 8-10+ yrs. progressive exp. in the dsn. of HVAC systems for inst. and comm. facilities. Ability and/or exp. in the direction of projects and staff, as well as client liaison and willingness to contribute directly to technical input is also req. Excellent comp. and long term growth is of fered in an expanding community. Contact our reps. in conf. at: G. Marshall Assoc., P.O. Box 66083, Chicago, IL 60666 .

DEPT. MANAGER-Req. by prominent Gulf Coast M/E firm. Qualified person should have degree and PE coupled with $8+$ yrs. exp. in the design and project dir. of HVAC systems for diverse comm., inst. and indust. bldgs. Proven exp. in project dir. and staff supv. along with client liaison is essential, Excellent comp. and long term future. Contact our reps. in conf. at: G. Marshall Assoc. P.O. Box 66083, Chicago, IL 60666.

MECHANICAL ENGR.-Position open with growing central Fla. firm. Degree and PE along with 6-8 + yrs. exp. in design and project engrg. for HVAC systems integral to inst., of fice and comm. facilities is req. Ability to assume project role and assist in direction of dept. is desired. Contact our reps. in conf. at: G. Marshall Assoc., P.O. Box 66083, Chicago, IL 60666.

MECHANICAL ENGR.-Position avail. with $\mathrm{M} / \mathrm{E}$ firm in the Midwest. Degree and PE preferred as well as ability to assume project respon. for comprehensive design of HVAC systems for comm., inst. and indust. projects. Excellent compensation and growth opportunities in a dynamic firm. Contact our reps. in conf. at: G. Marshall Assoc., P.O. Box 66083, Chicago, IL 60666.

MECHANICAL ENGR.-Position open with growing $A / E$ in the Midwest. Qualified person should have 3.5 yrs. exp. in the complete design of HVAC systems for inst., comm. and of fice projects. Degree and ability to assume project respon. in a growth environment is also req. Firm offers ex cellent salary and future in a growing community Contact our reps. in conf. at: G. Marshall Assoc., P.O. Box 66083, Chicago, IL 60666.

MECHANICAL DESIGN-Position avail. with dsn/bld mechanical contractor in the South. Qualified person should have $3.5+$ yrs. exp. in the design of HVAC systems for comm., office and inst. facilities. Degree preferred but not mandatory with ability to assume comprehensive dsn. and project respon. most important. Excellent compensation and long term future in an attractive high tech location. Contact our reps. in conf. at: G. Marshall Assoc., P.O. Box 66083, Chicago, IL 60666.

MECHANICAL ENGR.-Position avail. with prominent growing $A / E$ in the NE. Qualified person should have degree and $P E$ along with $8.10 \mathrm{yrs}$ exp. in the dsn. of HVAC systems for comm. and inst. facilities. Ability to assume multi-project respon., assist in direction of a dept. and maintain client liaison is also req. Contact our reps. in conf. at: G. Marshall Assoc., P.O. Box 66083, Chicago, IL 60666 .

REgIONAL SALES REPS-New England, Southwest \& Rocky Mountain areas. Major heat transfer equipment manufacturer seeks hydronic HVAC reps with experience. Direct sales to contractors, wholesalers, enduser. Specification work with architects and engineers. Excellent commission rates. Send resume to: Box 840, ASHRAE JOURNAL.

\section{MANUFACTURER'S REPRESENTATIVES}

The new Airtemp Applied Machinery Company is seeking quality Manu. facturer's Representatives.

Expanded sales have created excellent opportunities in some select areas. Must have knowledge of Ap. plied Equipment. (Air cooled chillers, air handlers, etc.), a good customer base and be results oriented.

Interested Parties please contact:

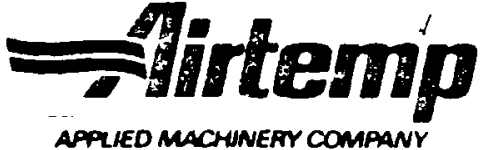

3003 WOODBRIDGE AVE. EDISON, NEW JERSEY 08818

PHONE "201.549.9850

ATTN: N.B. Eassa

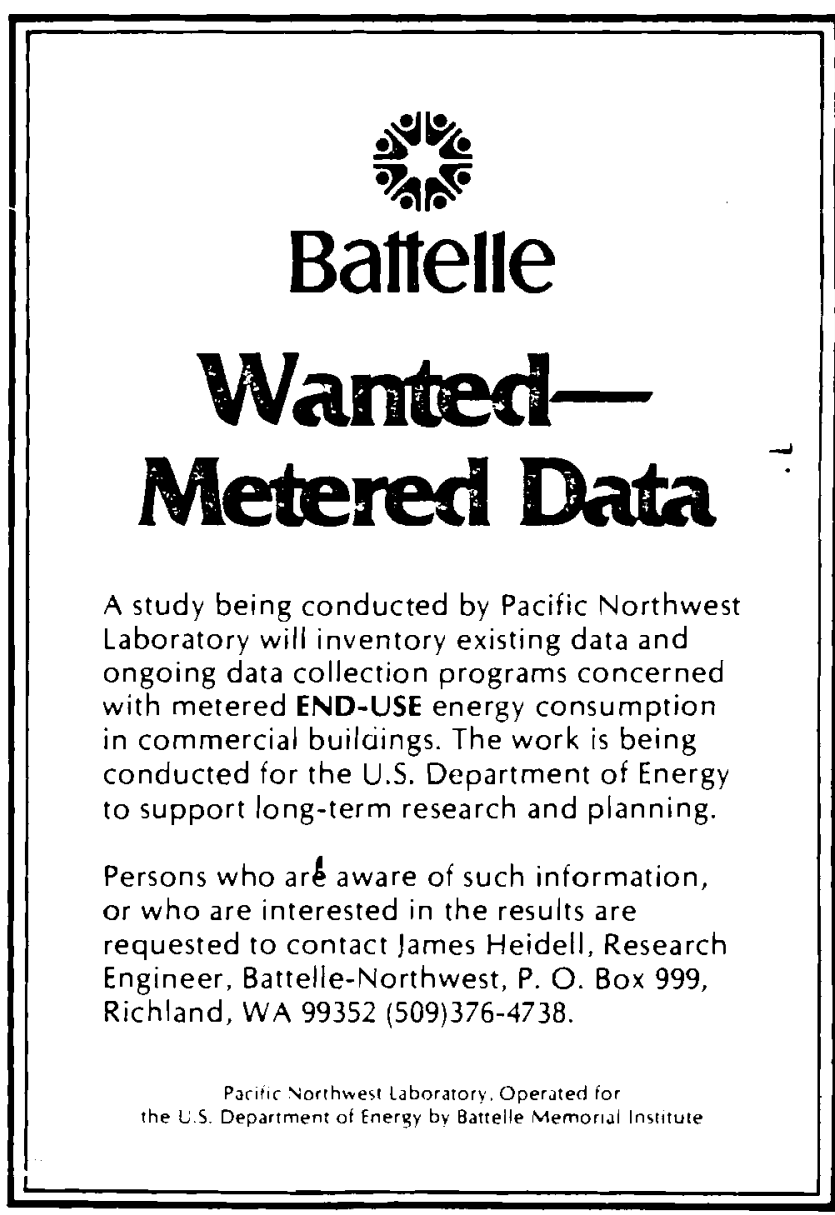



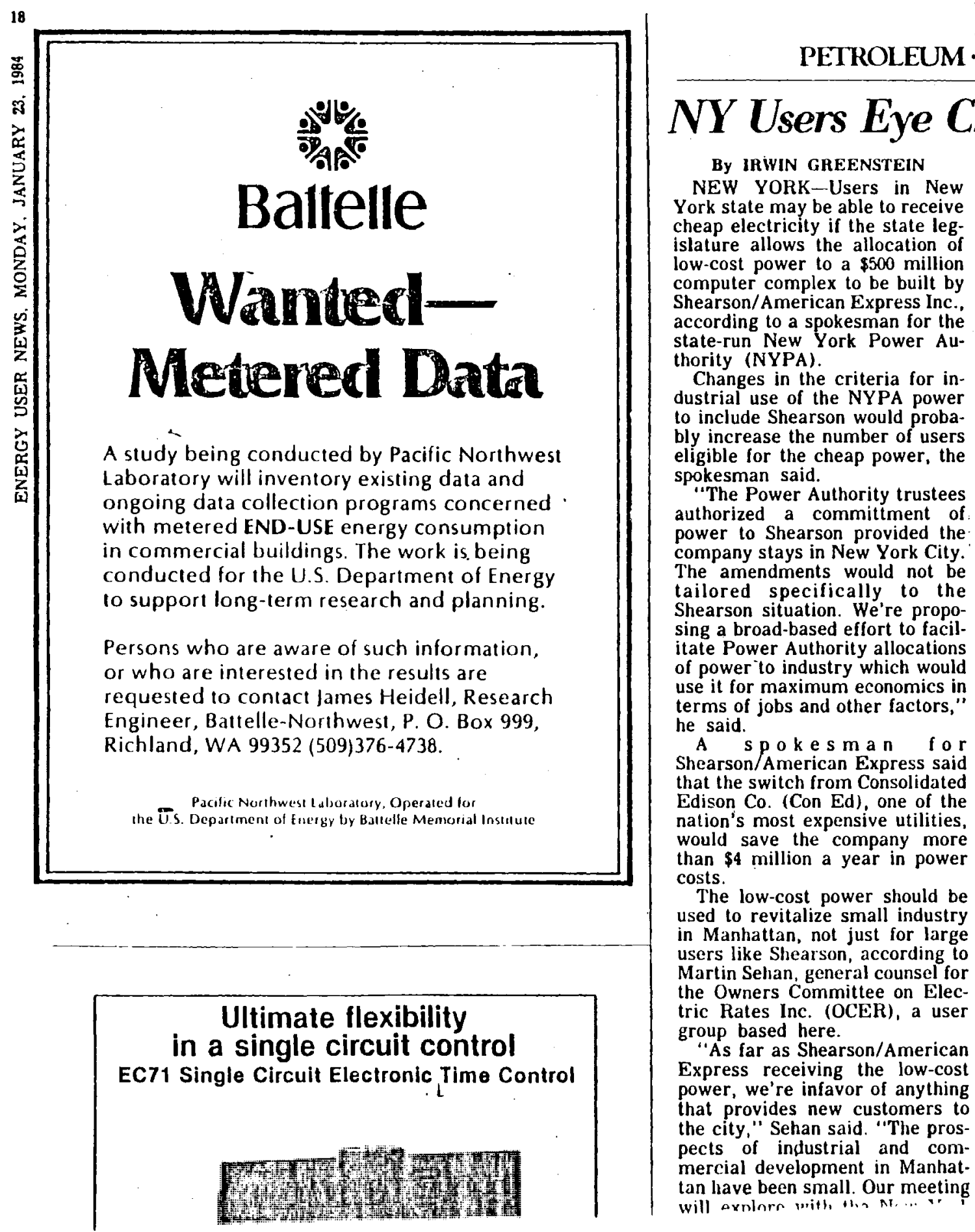

FUEL \& POWER

PETROLEUM · NATURAL GAS · COAL · ELECTRICITY

\section{NY Users Eye Cheap Elec, if Shearson Plan OK}

BY IRWIN GREENSTEIN

NEW YORK-Users in New York state may be able to receive cheap electricity if the state legislature allows the allocation of low-cost power to a $\$ 500$ milion Shearson/American Express Inc. according to a spokesman for the state-run New York Power Authority (NYPA).

Changes in the criteria for industrial use of the NYPA power to include Shearson would probably increase the number of users eligible for the cheap power, the spokesman said. authorized a committment of power to Shearson provided the company stays in New York City. The amendments would not be tailored specifically to the Shearson situation. We're proposing a broad-based effort to facilitate Power Authority allocations of power to industry which would use it for maximum economics in terms of jobs and other factors," he said.

A spokesman for Shearson/American Express said that the switch from Consolidated Edison Co. (Con Ed), one of the nation's most expensive utilities,
would save the company more would save the company more
than $\$ 4$ million a year in power

The low-cost power should be used to revitalize small industry in Manhattan, not just for large users like Shearson, according to Martin Selian , a user small. Our meeting
"The Power Authority trustees the Owners Committee on Elec
Shearson spokesman said. The company had considered constructing new offices in Jersey City, N.J.y across the Hudson River fronf its other Manhattan offices.

According $\%$ to Ira Liebowitz with the law firm of Leibowitz, Lasky and Peterson, Garden City, N.Y., the NYPA is authorized under state law to provide lowcost power to high-load factor manufacturers that will build new facilities in New york expand vided such power and energy made avallable to them.

According to the NYPA, a highload factor manufacturer is one whose cost of electricity normally represents at least 7.5 percent of its total product value, Liebowit added.

Shearson/American Expres now has a data-processing cente 3,400 people. The new computer complex, which will process messages between Shearson/American Express of fices worldwide is expected to add 2200 jobs to the city, said a Shearson spokesman.

If the amended legislation is passed, Shearson/American Express will not have to purchase power from con Ed, but expand existing facilities proin Manhattan that employee
theNYPA's James A. Fitzpa Nuclear Plant near upstate wego, N.Y, the spokesman Since 1981, the NYPA ha Madison Square Garden, York Cily, and Grumman A space Corp., Bethpage, N.Y attempts to keep them in York.

In 1981, Gulf and Westerm owners of Madison Squ Garden, announced plans to the sports complex because a million annual lossesause an office tower on the site an orfice tower on the site. S Wester to recelve subsi power: which saved $\$ 00,00$. year in electricity at Madi Square Garden, said a Po' Authority spokesmán.

But the Power Authority's location of cheap power to Gn man in 1983 to encourage company from relocating to olher state stirred prolests Long Island user groups who a wanted access to the low-c power. (See August 15, 15 EUN, page 4.)

Liebowitz, representing the tional Tooling and Machining sociation in addition to ano sociation in addition to anot user group, People Who $C$ were asserled that his clie located low-cost electricity Wuestern man subsidized power.

\section{FREE-MARKET PRICE OF NATURAL GAS}

The figures below are for scheduled purchases of natural gas by interstate pipelines, involving purchases exempt from legal price ceilings under Section 107 of the Natural Gas Policy Act. The average price for such gas peaked in August 1982 at \$7.44 per thousand cubic feet, but has fallen below $\$ 6$ since then.

\begin{tabular}{lll}
\hline Dollars per thousand cubic feet: & \\
& 1983 & $1982 \%$ Change \\
January ......................... $\$ 704$ & $77 \%$
\end{tabular}




\section{Requests for Data}

Wanted: Swap meet rental information. Base operator/master lease. Fairgrounds, racetracks, or other public facilities. Fixed/ percentage. Call collect, or write: Robert O. Cooley, SRPA, 315 W. 18th St., San Bernardino, CA 92405; (714) 882-7511.

Wanted: Information and comparable sales of condominium office buildings, in before or after condition, affected by flood and floodways. Will pay and/or share data. Contact: Bruce D. Greenberg, SRPA, Greenberg, Campbell, Chin, \& Assoc., 4937 E. 5th St., Tucson, AZ 85711; (602) 323-9324.

\section{Energy Data Wanted}

Battelle, Pacific Northwest Laboratory is coordinating an effort by the U.S. Department of Energy to develop a public domain data base for end-use energy consumption data pertaining to commercial buildings.

The data base will contain empirical enduse data for hourly and sub-hourly periods along with supporting micro climate and building characteristic data. The data base emphasizes "typical" commercial buildings. (End-use data on solar buildings is maintained in a separate data base.)

Battelle is currently finishing an inventory of ongoing or completed end-use data collection projects. The inventory will be used for the second stage of the projects: to assemble selected sources of metered data into a single consistently organized data base.

Readers who know of existing sources of metered data to include in the data base, and/or are interested in the results of the survey may contact: Jim Heidell, Economics \& Systems Analysis Section, Battelle Laboratory, P.O. Box 999, Richland, WA 99352; (509) 376-4738.

\section{SREA Market Data Center Elections}

The 1984 officers and directors of the SREA Market Data Center are as follows:

President

Joseph R. Stanfield, SRPA, MAI

Houston, Texas

Senior Vice President

Edward F. Sauterer, SRA

Cleveland, Ohio

Vice President

Sherwood Darington, SRPA

Salinas, California

Vice President

C. Benton Mosley

Scottsdale, Arizona

Treasurer

Donald E. Boyson, SRPA, MAI

Littleton, Colorado

Immediate Past President

Maurice W. Heckman, SRA

\section{Benchmarks}

$\begin{array}{ccc}\text { November } & \text { October } & \text { September } \\ 1983 & 1983 & 1983\end{array}$

Housing Starts

(seasonally adjusted annual rate) up 6\%

Single Family

$1,065,000$

Multi-Family

691,000

Total

$1,756,000$

$1,010,000$

down $13.5 \%$

$1,009,000$

643,000

$1,652,000$

Canadian Housing Starts

New Home Sales

New Home Median Price

638,000

635,000

632,000

$\$ 75,900$

\$ 76,100

$\$ 82,000$

Existing Home Sales

$2,630,000$

(Annual rate)

$2,610,000$

Existing Home Median Price

Unemployment

$\$ 70,400$

$\$ 70,400$

$8.8 \%$

$9.3 \%$

Canadian Unemployment

$11.3 \%$

Consumer Price Index

$(1967=100)$

301.8

Canadian Consumer Price Index

$(1981=100)$

Consumer Confidence Index

$(1969=100)$

90.2

Consumer Installment Debt

(Billions)

$\$ 358.0$

Total new construction

(millions of dollars)

$\$ 172,251$

$\$ 171,214$

$\$ 176,718$

Private construction

residential

nonresidential

Public construction

S 140,432

72,337

39,318

$\$ 139,377$

73,958

$\$ 143,119$

75,231

37,203

41,034

31,818

31,837

33,600

Mortgage rate (conventional) new home

$12.27 \%$

$12.25 \%$

$12.57 \%$ existing home

$12.57 \%$

$12.65 \%$

$12.86 \%$

Apt. Mortgages

$13^{1 / 8}-13 \frac{1}{1 / 2} \%$

$13-131 / 2 \%$

$13 \frac{1}{4}-133 / 4 \%$

$r=$ revised

* = Mortgage rate and participation or equity adding up to listed interest rate.

Sources: Citicorp Real Estate, Inc., Federal Home Loan Bank Board, Commerce Dept., Conference Board.

\section{Job Notices}

(Continued from page 6)

Wanted: Residential Appraiser. Atlantabased, large financial institution is seeking a designated appraiser with a minimum of five years supervisory skills in residential appraisal operation. Relocation experience and FNMA/FHLMC experience required. Send resume/qualifications, job history, and salary requirements to: Chief Appraiser, P.O. Box 1723, Atlanta. GA 30.301.
1 Wanted: Mid-level Appraiser. Professional with three to five years experience in single-family and residential condominium appraisals, and some knowledge of new construction. Salary and benefits commensurate with experience. Send resume to: Southwest Savings Assn., 9900 North Central Expressway, Suite 300, Dallas, TX 75231-4306; Attn: Appraisal Dept. 


\section{。 Battelle \\ Wanted- Metered Data}

A study being conducted by Pacific Northwest Laboratory will inventory existing data and ongoing data collection programs concerned with metered END-USE energy consumption in commercial buildings. The work is being conducted for the U.S. Department of Energy to support long-term research and planning.

Persons who are aware of such information, or who are interested in the results are requested to contact James Heidell, Research Engineer, Battelle-Northwest, P. O. Box 999. Richland, WA 99352 (509)376-4738.

Pacific Northwest Laborator. Operated for the U.S. Department or Energy bv Battelle Viemorial Institute

\section{EMERGING TECH/PRODUCTS}

Project management software - Package hands all aspects of project management on a single micro or personal computer, manufacturer says. System calculates start and finish dates with critical paths and prints activity reports and charts with numerable sort and select options. Resource management, materials management, and batch processing can also be incorporated into the software package. North America Mica, Inc.

For information circle $\mathbf{2 2 2}$

Multiple cable system - Commercial wiring system allows installer to pre-wire, add-on, or retrofit a project to accommodate power, telephone, and video from a single outlet, manufacturer says. Available fittings and accessories allow interconnection from telephone, CATV, or master antenna. Brand-Rex Co.

For information circle 173

Product bulletin - Describing solid state trip circuit breakers available in $1,600,2,000,2,500$, and 3,000 ampere frames. Bulletin features application, selection, and dimensional information including breaker operation and trip unit features. Breakers are designed for fixed or drawout mounting as a main, tie, or feeder circuit breaker. Square D Co.

For information circle 174

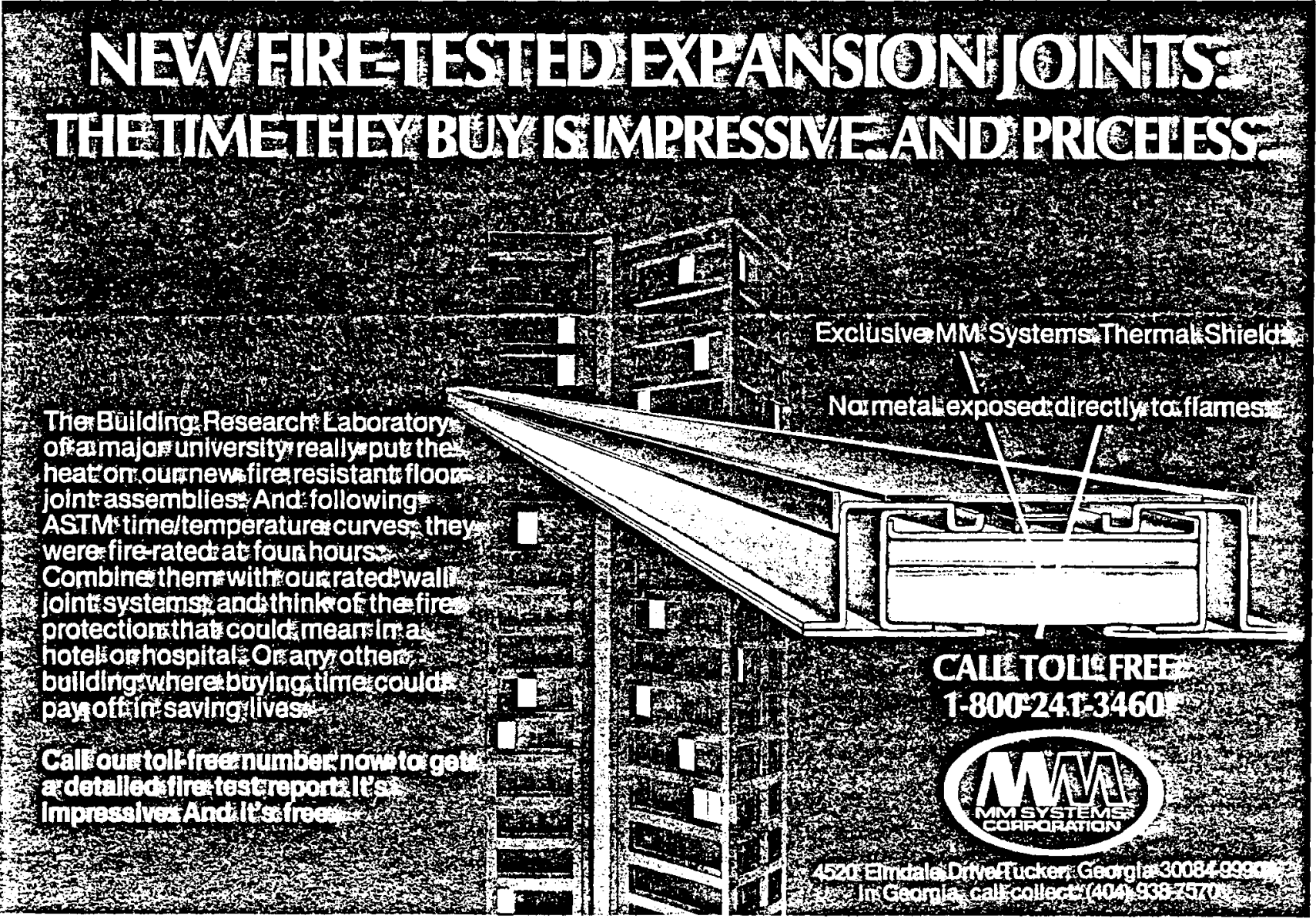

For information circle $\mathbf{5 2}$ 
1 
APPENDIX D

THE BONNEVILLE POWER ADMINISTRATION END-USE LOAD AND CONSERVATION ASSESSMENT PROGRAM (ELCAP)

OVERVIEW OF OBJECTIVES AND METHODS

This appendix provides an overview of the objectives and methods of an end-use metering effort underway in the Pacific Northwest: The End Use Load and Conservation Assessment Program (ELCAP). The project will instrument and audit 250 commercial buildings. Project activities are managed by Pacific Northwest Laboratory for the Bonneville Power Administration.

Since this overview was originally written, several modifications have been made to the program. The assessment of the effect of structural tightening measures on indoor air quality will be evaluated only by calculation of the apparent changes in air exchange rates from energy use measurements. Commercial buildings will be selected without respect to indoor air quality concerns, due to the fact that measures that effect indoor air quality are currently delayed pending the results of a detailed environmental impact statement.

The End-use Load and Conservation Assessment Program (ELCAP) is designed to support BPA's load forecasting and conservation program planning functions. Jointly sponsored by the BPA Offices of Power Management and Conservation, the ELCAP actually combines four different studies involving data collection in the residential and commercial sectors of the Pacific Northwest (PNW):

1. Hourly and peak forecasting;

2. Assessment of the effects of structure tightening measures on indoor air quality (IAQ);

3. Assessment of the effects of energy conservation measures and load management techniques on patterns of end-use loads.

4. Assessment of the effects of energy conservation measures and load management techniques on patterns of end-use loads. 
This consolidation of data collection efforts results in a significant cost savings to the government and PNW ratepayers and a substantial reduction in overall respondent burden with little or no sacrifice in the quality of the data.

Commercial sector

With partial BPA support, Seattle City Light (SCL) had initiated an enduse recording effort with a phased sample of first two, and eventually 12 commercial structures served by SCL. The ELCAP project is designed to build on the experience developed through SCL's efforts and to extend the results in two directions simultaneously. First, the sample will be extended to include a larger variety of buildings in Seattle. The second extension will be to include buildings that actually undertake energy conservation efforts.

This project brings together several BPA interests, including load forecasting, indoor air quality (IAQ), conservation assessment, and conservation marketing. The actual hourly end-use load data will serve as input to hourly load forecasting models; the results of the building simulations will support conservation assessment efforts; comparisons between the simulation results and actual usage patterns for buildings that adopt conservation measures will assist in calibrating the simulation models employed; and measures of indoor air quality will provide the first empirical evidence currently available.

The full study will encompass up to 250 buildings. Approximately 190 will be selected from the SCL service territory and up to 40 will be selected from successful applicants under the Commercial Financial Incentives Program (CFIP). Approximately 30 buildings will be selected for purposes of monitoring the indoor air quality, of which 10 will represent a subsample of the buildings in SCL. The remaining 20 buildings will be selected from two, as yet to be determined, clusters outside the city of Seattle. Each building will be fitted with multichannel hourly end-use recording equipment and will be subjected to a thorough energy audit. The building characteristics data from the energy audit will be input to standard heat loss simulation models (i.e., DOE2.1), and the results benchmarked to the actual usage patterns. It will then be possible to simulate the installation of various conservation measures and to derive estimates of the energy savings.

\section{2}


The sample of buildings from the SCL service territory will be designed to insure a distribution over the following twelve categories, based on the predominant activity:

- small office (less than $100 \mathrm{~K}$ sq. ft.)

- dry goods retail

- restaurant

- grocery

- warehouse

- hotel/motel

- theater/church/assembly

- school

- hospital

- multifamily

- mixed use.

Within each activity category, buildings will be selected so as to insure representation over the range of annual use of electricity.

Instrumentation of the buildings selected through SCL will be initiated in March 1984 and will be completed no later than 0ctober 1, 1984. Following the collection and preliminary examination of end-use data for a period of at least a week, each building will be thoroughly inspected and a portion of the results placed in a machine readable record. These "characteristics" data will be used as input to building simulation heat loss models. Following calibration of the models against the actual load data, the models will be used to assess the potential impacts of conservation measures considered likely by the inspection team.

With the owner's informed consent, the levels of specified pollutants will be monitored in a group of up to 30 buildings. Economic conservation measures will be implemented in a subset of up to 12 buildings, including measures that affect the rates of air exchange, and the levels of air pollutants will be monitored once again. Mitigation measures will be offered in any case where conservation measures adversely impact IAQ to a level exceeding established standards of safety. 
The third group of buildings to be included in this project consists of those involved in projects receiving funding under BPA's CFIP. Participation in the CFIP involves the adoption of conservation measures estimated to be cost-effective and acceptable under the limits established by BPA's current Environmental Impact Statement. An attempt will be made to instrument buildings from the CFIP as soon after acceptance as possible and at least one month prior to the adoption of the proposed measures.

Electricity demand data will be collected on an hourly basis for each of the major end-uses in each building. End-uses metered depend on the type of activities occurring in the building. For each activity category, a core set of end-uses will be monitored in each building. The availability of each of the loads for separate monitoring will be a criteria for selection into the final sample. To the extent that they are available as separate loads, additional loads will be considered for monitoring depending on the percentage of the total load accounted for by the end-use.

With the possible exception of certain warehouses, it is likely that the following three end-use loads will be monitored in every building:

1. space heating, ventilating, and cooling (HVAC);

2. water heating; and

3. lighting

other end-uses to be monitored, depending on the predominate activity category, include;

4. food refrigeration and freezing;

5. cooking;

6. computers;

7. laundry equipment;

8. other large specialized equipment; and

9. elevators and escalators;

Additional end-uses may be monitored, as appropriate. In addition, certain buildings may be divided into zones, and end-use loads monitored separately for each zone. Microweather data (temperature, humidity, and wind) will be monitored for a subset of buildings. 
Data Acquisition and Processing

Three categories of data wil1 be collected:

1. Hourly electricity demand for each major end-use;

2. Characteristics of the structure and;

3. Behavior and attitudes of the owner and occupants.

Hourly End-Use Data: A solid-state, multichannel recorder designed by Pacific Northwest Laboratory will be used to collect electricity demand for each major end-use on an hourly basis. Depending on the number of end-use loads monitored, data are stored for between 7 and 30 days. At appropriate intervals, the stored data are retrieved using telephone-based automatic remote interrogation equipment. Following retrieval, the data will be reviewed for completeness and consistency; then transferred to permanent storage on 9 track magnetic tape. Periodically, the data will be summarized and the summaries placed in flat files in preparation for analysis using any of the standard statistical packages.

Characteristics of the Structure: Information concerning the thermal envelope and operating characteristics of the major end-using equipment will be obtained through detailed energy audits conducted by trained personnel. The form used in the commercial sector will likely be subdivided so that it may be more efficiently administered in each of the activity categories.

Al1 of the forms will be constructed so as to facilitate transfer to machine-readable form and the data placed on magnetic computer tape. The data will be organized into flat files in preparation for analysis using standard statistical software. The files will be structured so as to facilitate merger with the end-use data.

Behavior and Attitudes of Owners and 0ccupants: A large portion of the sample residences will be selected from those which participated in the 1983 PNWRES. Selection critical characteristics will be verified prior to equipment installation. The results of the complete energy inspection will then be compared with the survey responses, producing both an index of validity for use in conjunction with the survey data; and an index of occupant knowledge for use in conjunction with both the survey and the end-use load data. Residents will be 
periodically queried concerning alterations made to the thermal envelope and the major end-use equipment. These and additional queries will be made in an effort to measure characteristics of the occupants' behavior and attitudes which may contribute to explanations of observed end-use load patterns. Data from these inquiries will be transferred to machine-readable flat files and prepared for possible merger with the characteristics and end-use data files.

Data comparable to that from the PNWRES 83 does not exist for any of the commercial buildings. Furthermore, previous attempts to replicate residential methodologies in the commercial sector have proved to be expensive and of dubious value. A search for more cost-effective methods will be conducted as a part of this project. 
APPENDIX E

B IBLIOGRAPHY 
1.

i 
APPENDIX E

BIBLIOGRAPHY

1. XENERGY. November 1981. A Description of Building Energy Use Data Bases. National Institute of Building Sciences. DOE/CS/22046-2. Washington, D.C..

2. Reznek, Ben. July 1978. An Annotated Compilation of the Sources of Information Related to the Usage of Electricity in lon-Industrial Applications. PB-285 260. National Engineering Laboratory, national Bureau of Standards, Washington, D.C.

3. Booz Allen and Hamilton. September 1983. Passive Solar Commercial Building Program, Case Studies. DOE/CE-0042. U.S. Department of Energy.

4. Utesch, A. L. July 1982. Energy Management at Dallas/Fort Worth Airport. ASHRAE Journal.

5. Kirkpatrick, Donald. 1981. "A Unique, Low-Energy Air-Conditioning System Using Naturally-Frozen Ice." Proceedings of the 1981 Annual Meeting, American Section of the International Solar Energy Society.

6. ASHRAE Report, Energy Calculations for Load Profiles and Energy Requirements for Heating and Cooling of Buildings.

7. Hittman Associates, Inc. February 1980. Development of a Data Base and Forecasting Model for Commercial Sector. Electricity Usage and Demand Volume VI Establishment Characteristics. California Energy Commission.

8. May, William B. September 1981. Analysis of Data from the Energy Monitoring and Control System at the Norris Cotton Federal Office Building. NBSIR 81-2358. U.S. Department of Commerce, U.S. Department of Energy.

9. Spielvogel, Larry. November 1982. ASHRAE Journal

10. Atmospheric Sciences Research Center. August 1978. Jolly Tiger Restaurant/Colonie, New York Energy Conservation and Heat Reclamation Project. U.S. Department of Energy.

11. Hospitality, Lodging and Travel Research Foundation, Inc. December 1981. Summary Report of Energy Usage/Consumption Analysis for Six Hotels/Motels. U.S. Department of Energy. 
.

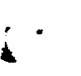

$y^{\circ}$

! 


\section{DISTRIBUTION}

No. of

Copies

OFFSITE

$10 \mathrm{Mr}$. Ted Kurkowski

Office of Building Energy

Research \& Development

U.S. Department of Energy

Washington, DC 20585

Marvin Gorelick

U.S. Department of Energy

Washington, DC 20545

30 DOE Technical Information Center

Min Kantrowitz

Min Kantrowitz Associates

P.0. Box 792

Albuquerque, NM 87103

Walt Ingle

Rockwell International/ETEC

P.0. Box 1440

Canoga Park, CA 91304

Mike McGrath

Edison Electric Institute

1111 19th St. NW

Washington, DC 20036

Ed Berdsworth

Electric Power Research Institute

3412 Hillview Avenue

Palo Alto, CA 94304

Ed Pollock

VITRO Laboratories Division

14000 Georgia Avenue

Silver Spring, MD 20910

Keith Davidson

Gas Research Institute

8600 West Bryn Mawr Ave.

Chicago, IL 60631
No. of

Copies

Mike Holtz

Architectural Energy Corp.

8753 Yates Drive

Suite 105

Westminister, CO 80301

Jeff Haris

Lawrence Berkeley Laboratories

Building 90

Berkeley, CA 94720

Ed Holt

Seattle City Light

Conservation \& Solar Division

$10153 r d$ Avenue

Seattle, WA 98105

Phil Wendell

U.S. Department of Energy

Bonneville Power Administration

P.0. Box 3621

Portland, OR 97208

Earl Kenneth

American Institute of

Architects

1735 New York Avenue NW

Washington DC 20006

Larry Brand

c/o Owens Corning Fiberglass

Technical Center

Granville, Ohio

Dennis Miller

Mail Station 36

Johnson Controls, Inc.

P.0. Box 423

Milwaukee, WI 53201

Khris Subharao

Solar Energy Research Institute

1617 Cole Boulevard

Golden, CO 80401 
No. of

Copies

Larry Palmiter

Ecotope Inc.

2332 E. Madison

Seattle, WA 98112

Doug Hittle

CERL

Champaign, Illinois

4 Richard Wright

ASHRAE

1791 Tullie Circle, NW

Atlanta, GA 30329

ONSITE

DOE Richland Operations Office

H. E. Ransom/D. R. Segna
No. of

Copies

36 Pacific Northwest Laboratory

R. M. Fleischman

J. C. Franke

J. A. Heidell (15)

S. L. Lucas

R. P. Mazzucchi (5)

S. H. Pansky

R. W. Reilly (3)

R. G. Rivera

Energy Systems Library

Publishing Coordination (2)

Technical Information MH (5)

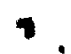

$\therefore \cdot$ 